\title{
Timing and Survival of American Eels Migrating Past Hydroelectric Dams on the Shenandoah River
}

\author{
Sheila M. Eyler
}

Follow this and additional works at: https://researchrepository.wvu.edu/etd

\section{Recommended Citation}

Eyler, Sheila M., "Timing and Survival of American Eels Migrating Past Hydroelectric Dams on the Shenandoah River" (2014). Graduate Theses, Dissertations, and Problem Reports. 5561.

https://researchrepository.wvu.edu/etd/5561

This Dissertation is protected by copyright and/or related rights. It has been brought to you by the The Research Repository @ WVU with permission from the rights-holder(s). You are free to use this Dissertation in any way that is permitted by the copyright and related rights legislation that applies to your use. For other uses you must obtain permission from the rights-holder(s) directly, unless additional rights are indicated by a Creative Commons license in the record and/ or on the work itself. This Dissertation has been accepted for inclusion in WVU Graduate Theses, Dissertations, and Problem Reports collection by an authorized administrator of The Research Repository @ WVU.

For more information, please contact researchrepository@mail.wvu.edu. 


\title{
Timing and Survival of American Eels Migrating Past Hydroelectric Dams on the Shenandoah River
}

\author{
Sheila M. Eyler \\ Dissertation submitted \\ to the Davis College of Agriculture, Natural Resources, and Design \\ at West Virginia University \\ in partial fulfillment of the requirements for the degree of \\ Doctor of Philosophy in \\ Forest Resource Science
}

Stuart Welsh, Ph.D., Chair

David Smith, Ph.D.

Kyle Hartman, Ph.D.

Todd Petty, Ph.D.

Steven Minkkinen

Division of Forestry and Natural Resources

Morgantown, West Virginia

2014

Keywords: American Eel, silver eel, downstream migration, hydroelectric, turbine mortality, environmental variables, nighttime turbine shutdowns, radio telemetry, Shenandoah River, Potomac River

Copyright 2014 Sheila M. Eyler 


\title{
ABSTRACT \\ Timing and Survival of American Eels Migrating Past Hydroelectric Dams on the Shenandoah River
}

\begin{abstract}
Sheila M. Eyler
Hydroelectric dams can impact downstream migrating American Eels (Anguilla rostrata) through migratory delays and turbine mortality. I used radio telemetry to determine the timing and survival of American Eels migrating downstream past five hydroelectric dams on the Shenandoah River in Virginia and West Virginia and through a portion of the Potomac River in Maryland. The five hydroelectric dams implemented a seasonal nighttime turbine shutdown period to protect downstream migrants. The shutdown period was conducted from September 15 to December 15 annually, from 18:00 to 06:00 hours daily. During the fall months from 2007 to 2009, large American Eels were collected primarily by electrofishing above the Luray, Newport, and Shenandoah dams. A total of 145 American Eels were radio-tagged and released near their capture location. All five hydroelectric dams were outfitted with telemetry monitoring equipment to determine the time of arrival to the dam, the time of passage at the dam, the method of passage at a dam, and immediate mortality of tagged fish. Telemetry equipment at the dams was deployed during the fall of 2007 and monitored continuously through the summer of 2010.

A total of 96 tagged American Eels migrated downstream past at least one dam during the study. Downstream passage events occurred during every month of the year except July, with peak migrations in the fall and spring months. The peak timing for downstream migration was different for each of the three study years. A total of $67 \%$ of the downstream migration events occurred during the assumed fall migration period (September 15 to December 15). Most (90\%) downstream migration events occurred between sunset and sunrise and $81 \%$ occurred during the hours used for turbine shutdowns (18:00-06:00 hours). American Eels usually completed downstream migrations during one study year (August 1 to July 31) and multi-year downstream migratory activity for an individual was rarely observed.

Migration out of the Shenandoah River generally took one month to complete, with a mean migration time of $38 \mathrm{~d}$ for American Eels to pass all five dams at a distance of $195 \mathrm{~km}$. The majority (81\%) of migratory delay experienced at each dam was less than 24 hours in the Shenandoah River. Mean travel speed was similar between the Shenandoah River $\left(29 \mathrm{kmd}^{-1} \pm\right.$ 12 SE with five hydroelectric dams) and the Potomac River ( $26 \mathrm{kmd}^{-1} \pm 6.6$ SE with only one low head non-hydroelectric dam), suggesting that hydroelectric dams on the Shenandoah River did not cause a substantial migratory delay.

Environmental variables were associated with downstream migration events of American Eels. River discharge, proportional increases in river discharge, and water temperature were significant factors in describing when downstream migration events occurred during the study. A logistic regression model was able to accurately describe when downstream migration events occurred $85 \%$ of the time. Lunar phase, time of year, and dam
\end{abstract}


location were not significant variables in describing when downstream migration events occurred.

A total of 28 American Eels experienced immediate turbine mortality during the study. Turbine mortality occurred at all Shenandoah River dams, with individual dam turbine mortality rates ranging from $16 \%-41 \%$ for American Eels passing through turbines. Project mortality rates ranged from $9 \%$ to $38 \%$ during regular turbine operation and those rates were reduced to $0-6 \%$ during the turbine shutdown periods. During all operation scenarios (turbine shutdowns and regular operation), overall mortality rates at each dam ranged from 3-14\%, with a cumulative mortality for American Eels passing all five dams of 37\%. The seasonal nighttime turbine shutdown period encompassed $50 \%$ of the downstream migration events and reduced, but did not eliminate, mortality to downstream migrating American Eels.

Shenandoah River dams likely have little impact on migration delay for American Eels; however, downstream migrations during turbine operation could reduce the number of American Eels leaving the Shenandoah River by $67 \%$. Turbine shutdowns reduced or eliminated mortality during downstream migration events at the Shenandoah River dams. The current time period for implementation of nighttime turbine shutdowns (September 15-December 15) encompassed two-thirds of downstream migration events, however American Eel passage only occurred on a small portion of days during the shutdown period on any given year. On the Shenandoah River, the nighttime turbine shutdown period could be more protective for downstream migrating American Eels if it were implemented based on environmental variable triggers. 


\section{Dedication}

I dedicate this dissertation to my husband, Brian Eyler, for his encouragement and support of me pursuing my education and my career, and for being a wonderful husband, friend, and father to our children. I also dedicate this dissertation to my children, Michael and John for their patience and understanding during the completion of this project. 


\section{Acknowledgements}

Many people have assisted me in pursuing my degree, and without their help, completing this process would not have been possible. Mary Rockey was instrumental in helping with the field work and teaching me so much about radio telemetry. Her tireless efforts of working odd hours and trying new techniques provided great value to the quality of this project and her friendship was a bonus. David Smith's support of the field aspects of the project as well as his tireless efforts to teach me statistics made me strive to work harder to make a better product. I am grateful for the support of my employer, the U.S. Fish and Wildlife Service, and specifically, the staff at the Maryland Fishery Resources Office, including Steve Minkkinen, Mike Mangold, Ian Park, Josh Newhard, Julie Devers, and Myra Heineman, in helping me with field work, acting as a sounding board for ideas, and offering suggestions on how to improve the project. I thank John Sweka for answering statistical questions and helping me transfer information gained from the Shenandoah River to similar issues with American Eel on the Susquehanna River. I thank the various people who came out to help me collect eels in the field and download telemetry data, including Mike Mangold, lan Park, Dustin Smith, Josh Newhard, and Brian Eyler. I thank my committee members; Steve Minkkinen, Kyle Hartman, Todd Petty, and David Smith for helping me develop this project and see it through to completion. I thank Pat Mazik for her help in navigating me through the degree program with the National Conservation Training Center. Finally, I thank my advisor Stuart Welsh, for sparking my interest in American Eel, participating in the field work - including driving the electrofishing boat into 
the wee hours of the morning, for his continuous positive attitude, his thorough reviews of this document, and most of all, his unwavering support and patience during this process. 


\section{Table of Contents}

Chapter 1 - Impacts of dams on American Eel (Anguilla rostrata) migration, life history, survival,

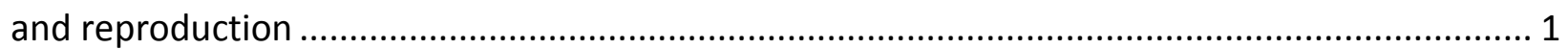

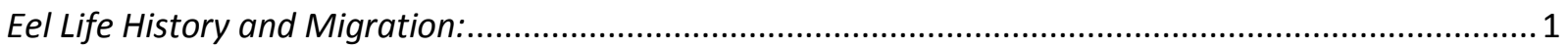

Impact of Dams on Eel Distribution and Life History Traits: ............................................................. 7

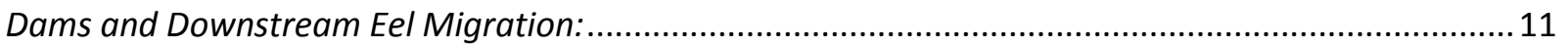

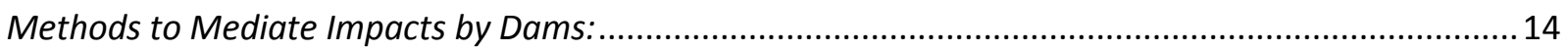

Summary-Benefits of Dam Mediation for Eel Migrations: ................................................................. 19

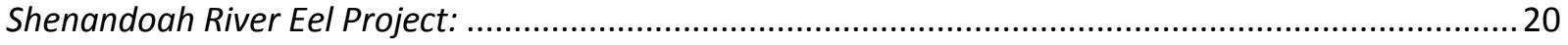

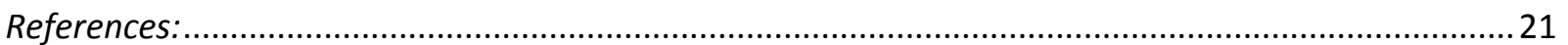

Chapter 2 - Evidence for spring downstream migrations in silver American Eel (Anguilla rostrata) in the Potomac River basin, USA ......................................................................... 38

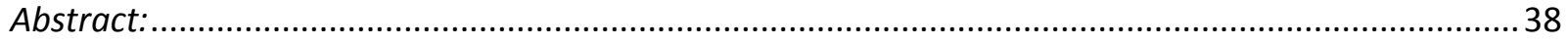

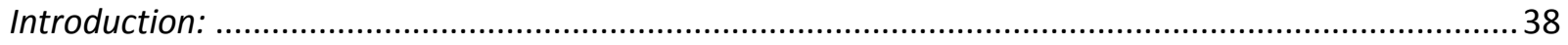

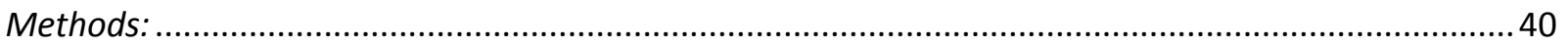

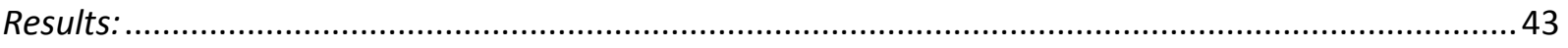

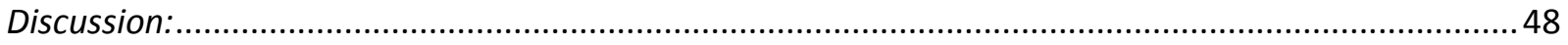

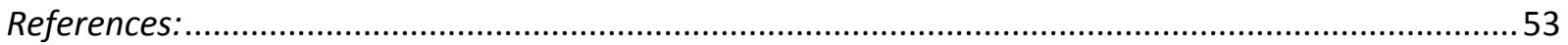

Chapter 3 - Environmental variables associated with American Eel (Anguilla rostrata) downstream migrations in the Shenandoah River ................................................................ 63

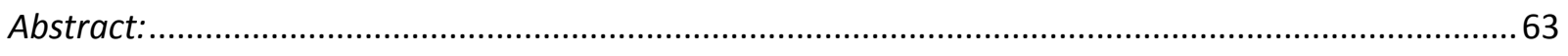

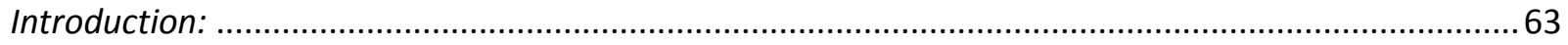

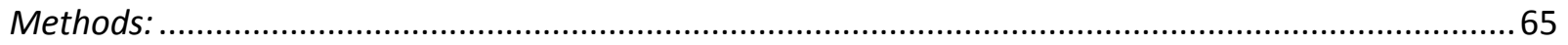

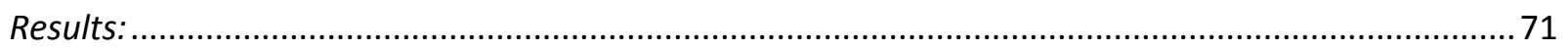

Discussion:

References:

Chapter 4 - Passage method, turbine mortality, and migratory delay of silver American Eels (Anguilla rostrata) at five hydroelectric dams on the Shenandoah River ................................. 91

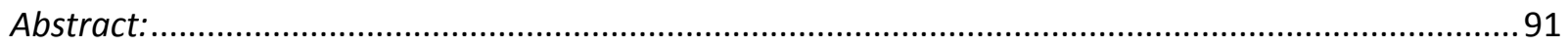

Introduction:

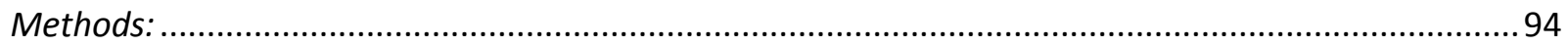

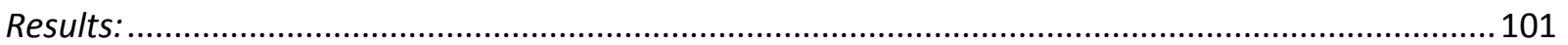


Discussion: .............................................................................................................. 109

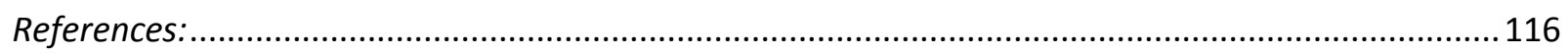

Chapter 5 - Management actions for protecting downstream migrating American Eels (Anguilla

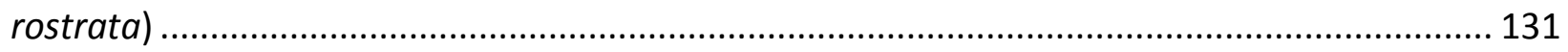

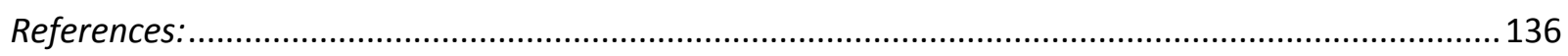

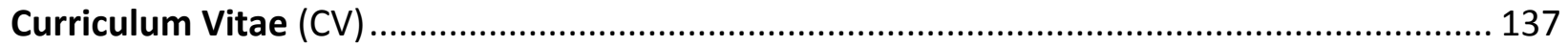

*Note-Some formatting differences, such as citation format, exist between chapters due to specific requirements for journal submission 


\section{List of Tables}

\section{Chapter 3}

Table 1. Environmental and other associated variables evaluated in logistic regression modeling to describe silver American Eel migrations on the Shenandoah River from 2007 through 2010

Table 2. Mean daily discharge during the study period and during downstream passage events for American Eels migrating past five dams on the Shenandoah River. Discharge data were taken from U.S. Geological Survey gauging stations at Lynwood, Luray, and Front Royal, Virginia, and Millville, West Virginia

Table 3. Logistic regression models considered for describing environmental variables associated with downstream migration events for silver American Eel on the Shenandoah River from 2007-2010

Table 4. Parameter estimates for best-fitting logistic regression model $(\mathrm{BIC}=1625)$ using environmental variables to describe silver eel migrations past dams on the Shenandoah River from 2007-2010. The constant includes TempB 1. The odds ratios for TempB 2, 3, 4, and 5 are the odds of passage in those water temperature ranges compared to odds of passage within the range of water temperatures in TempB 1

\section{Chapter 4}

Table 1. Percentage of time spent between first detection and passage at each hydroelectric dam on the Shenandoah River (number of individuals in parentheses)

Table 2. Migratory delay at different river discharge levels for American Eels migrating past five hydroelectric dams on the Shenandoah River from September 2007 through August 2010... 122

Table 3. Turbine mortality rates of American Eels that passed four hydroelectric dams on the Shenandoah River from September 2007 through August 2010.

Table 4. Turbine mortality of American Eels at five hydroelectric dams on the Shenandoah River from September 2007 through August 2010

Table 5. Passage method and turbine mortality for American Eel migrating downstream during nighttime turbine shutdowns (15 September to 15 December, 18:00 to 06:00 hours) compared to regular operation at five dams on the Shenandoah River from September 2007 through August 2010. The 95\% confidence limit is noted in parentheses. 125 


\section{List of Figures}

\section{Chapter 2}

Figure 1. Shenandoah and Potomac river watersheds and location of five hydroelectric dams and a water supply dam and reservoir monitored with stationary radio telemetry for silver American Eel passage. All silver American Eel collection and tagging occurred in the Shenandoah River watershed upstream of the Luray Dam. 58

Figure 2. Percent of American Eel passage events by month during the three study years on the five hydroelectric dams on the Shenandoah River, and the Little Falls Dam and Dalecarlia Reservoir on the Potomac River. Eel passage was monitored continuously from September 2007, through August 2010. Annual study periods began on September 1 and continued through August 31 of the following year.

Figure 3. Percent of American Eel passage events by month for successful (fish migrating past a Potomac River monitoring station) and non-successful (fish not detected at a Potomac River monitoring station) migrants in the Potomac River basin

Figure 4. Daily average river discharge values compared to cumulative American Eel dam passage events by study year (1 September to 31 August, 2007-2010) in the Potomac River basin. Note different scale of river discharge between study years

Figure 5. Percent of American Eel dam passage events by hour relative to sunset at five hydroelectric dams on the Shenandoah River, and the Little Falls Dam and Dalecarlia Reservoir on the Potomac River from 2007-2010. Sunset occurred between hours -1 and 0.

\section{Chapter 3}

Figure 1. Shenandoah River watershed and location of five hydroelectric dams monitored with stationary radio telemetry for silver American Eel passage. All collection and tagging occurred upstream of the Luray Dam 88

Figure 2. Percent of downstream American Eel passage events at five dams on the Shenandoah River from 2007 through 2010. Eel passage events were pooled for all dams by day and discharge data were taken from U.S. Geological Survey gauging station at the Luray Dam. Note scales are different between graphs 89

Figure 3. Water temperature during downstream passage events for American Eel migrating past five hydroelectric dams on the Shenandoah River from 2007 through 2010. Water 
temperature data were taken from U.S. Geological Survey gauging station at the Luray Dam

\section{Chapter 4}

Figure 1. Potomac and Shenandoah river watersheds and location of five hydroelectric dams monitored with stationary radio telemetry for silver American Eel passage. All collection and tagging occurred upstream of the Luray Dam

Figure 2. Generalized diagram of telemetry monitoring antenna array at a Shenandoah River Dam. The antenna indicated by a star is an aerial 6-element Yagi with a detection distance of about $1 \mathrm{~km}$ (the entire area of the diagram). Antennas indicated by triangles are underwater antennas with a detection distance identified by the shaded area (range from $5 \mathrm{~m}$ to $15 \mathrm{~m}$ ).. 128

Figure 3. Percent of American Eel passage events by month during the three study years on the five hydroelectric dams on the Shenandoah River. Passage was monitored continuously from September 2007 through August 2010. Annual study periods began on 1 September and continued through 31 August of the following year

Figure 4. Percent of American Eel passage events by hour of day during the season of turbine shutdowns (15 September to 15 December) and during the rest of the year at five hydroelectric dams on the Shenandoah River from 2007-2010..... 130 
Chapter 1 - Impacts of dams on American Eel (Anguilla rostrata) migration, life history, survival, and reproduction

\section{Eel Life History and Migration:}

The American Eel (Anguilla rostrata) is a panmictic species that can be found in the coastal waters and tributaries of the western Atlantic Ocean. The American Eel population has no geographically distinct population units within its range from Greenland to northern South America (Avise et al. 1986; Côté et al. 2013; Pujolar 2013). In addition, the American Eel is a semalparous and catadromous species which spawns in the Sargasso Sea. Although spawning has never been observed and eggs have not been collected, spawning is thought to occur in late winter based on collections of leptocephali (larvae) (Kleckner and McCleave 1985; McCleave et al. 1987).

The early life history stages of American Eel occur in the ocean environment. The eggs are hatched in the Sargasso Sea, resulting in leptocephali. The leptocephali then travel on ocean currents for about a year until they are deposited onto the Continental Shelf. Once they reach the Continental Shelf, the leptocephali undergo metamorphosis into the glass eel stage. Glass eels actively swim toward the North American coast, generally during late winter through spring. The timing of arrival of glass eels to the shores of the North American coast varies annually, but typically occurs during late winter in more southern latitudes through midsummer in the Canadian Provinces (Dutil et al. 1989; Jessop 1998; Wang and Tzeng 2000; Powles and Warlen 2002; Overton and Rulifson 2009; Sullivan et al. 2009). 
During the continental phase of the American Eel life cycle, glass eels arrive to the shores of the Atlantic Coast, and begin upstream migrations for the growth and maturation phases of the life cycle. Glass eels begin upstream migrations into estuaries and tributaries, and after a short period of time, the glass eel becomes pigmented and is known as an elver. During spring and summer months, elvers either begin residency in estuarine or coastal areas or continue migrations upstream into fresh water (Richkus and Whalen 1999).

Migration of American Eel elvers into upstream habitats varies with regard to timing and also body size depending on latitude on the North American coast. Upstream migration occurs in late winter and early spring in southern latitudes and through the summer and early fall in northern latitudes (Martin 1995; Jessop 2000; Schmidt et al. 2009; Welsh and Liller 2013). Migrants are typically smaller in southern latitudes and increase in size in northern locations. Upstream migration may take more than one year to complete. Migrations start in the elver life stage (60 to $150 \mathrm{~mm} \mathrm{TL}$ ) and after about one year inland elvers transform into yellow eels (>150 $\mathrm{mm} \mathrm{TL}$ ), so that multi-year upstream migrations can occur through a portion of the yellow phase as well. As a result of the long-term upstream migrations, eels increase in size with distance upstream from the ocean (Haro and Krueger 1991). Upstream migration for the eels is correlated with environmental variables, with peaks in migration associated with water temperature, lunar phase, river discharge and tidal cycles (Sorensen and Bianchini 1986; Martin 1995; Jessop 2003; Schmidt et al. 2009; Welsh and Liller 2013).

American Eels utilize a diverse suite of life history strategies which can influence migratory patterns, sex determination, growth rates, and survival. American Eels have the ability to complete their growth phase of their life cycle solely in brackish water, migrating 
frequently between brackish and fresh water, or residing exclusively in fresh water (Morrison et al. 2003; Jessop et al. 2008). Migratory patterns can influence eel densities, with eel densities typically higher in estuarine areas and lower in upstream areas (Smogor et al. 1995). Sex determination in the American Eel is likely density dependent (Krueger and Oliveira 1999), with sex being determined between the first and second year after arriving to the coast (Melià et al. 2006). In lower density freshwater habitats, the proportion of female eels is higher, if not exclusively female (DeLeo and Gatto 1996; Jessop 2010), whereas high density coastal stream populations can be predominantly by males (Krueger and Oliveria 1999). Growth rates are influenced by migration with higher growth rates in more productive estuarine areas compared to freshwater areas (Morrison and Secor 2003; Lamson et al. 2009). Although growth rates are lower in upstream areas, female eel maximum size increases with increased distance from the ocean (Helfman et al. 1987; DeLeo and Gatto 1996). Despite advantages to growth in saline water, many young eels make extensive upstream migrations to occupy headwaters of coastal tributaries. The shift to female dominated populations, in addition to increased survival with reduced eel densities upstream areas (DeLeo and Gatto 1996), provides advantages for some portion of the population to migrate upstream. The diversity of habitats occupied by American Eels may provide an evolutionary advantage to the species by allowing them to occupy diverse habitats as well as protecting them from any impacts that may occur to any single habitat type (Cairns et al. 2009).

The age and size at maturity is also influenced by the migratory pattern of juvenile eels. American Eels can spend 4 to 20 or more years in estuarine and fresh water areas before reaching maturity. For male eels, maturity is likely driven by size, rather than age, with southern 
male eels reaching maturity within 4 years of arriving at the coast and northern male eels taking 8 to 10 years to reach the same size (average $350 \mathrm{~mm}$ ) at maturity (Harrell and Loyacano 1982; Facey and Helfman 1985; Oliveira and McCleave 2000; Jessop et al. 2009). Female eels are much more variable in their maximum size and age at maturity, but typically take longer than males to mature and mature at a larger size than males (Facey and Helfman 1985; Oliveira and McCleave 2000). Mature estuarine female eels are typically much smaller and younger than their freshwater counterparts (Smogor et al. 1995; Goodwin and Angermeier 2003; Morrison and Secor 2003; Owens and Geer 2003). In upstream areas, female eels can take 15 to 20 years or more to mature and can reach sizes in excess of one meter (Goodwin and Angermeier 2003; Tremblay 2009).

Fecundity is related to maximum size at maturity for female eels. Large freshwater eels may have as many as 20 million eggs or more compared to as few as two million eggs in mature estuarine eels (Wenner and Musick 1974; Tremblay 2009). The tradeoff for high fecundity in freshwater eels is reduced growth rates and older age at maturity which may increase the risk of natural mortality. Large freshwater eels are also at risk from anthropogenic mortality as they must travel long distances downstream past dams and other in-river obstacles to reach the spawning grounds in the Sargasso Sea. Estuarine eels may grow faster and mature at a younger age, however, they are also subject to anthropogenic mortality through commercial fishery harvest.

Upon maturation, American Eels undergo a process of silvering that consists of changes in morphology and physiology to prepare themselves for the long migration to the Sargasso Sea and spawning. The changes include changing color from yellow/green to bronze/black, 
fattening of the body, thickening of the skin, enlargement of the eye and change in visual pigment, increased length of capillaries in the rete of the swim bladder, change in gill structure for osmoregulation in sea water, digestive tract degeneration, enlarging of pectoral fins, and late stage oocyte development (Dutil et al. 1987; McGrath et al. 2003). Yellow eels begin this transition to the silver stage while in freshwater and estuarine habitats and finish the transition during downstream migrations between estuaries and the open ocean (Wenner 1973; Facey and VanDenAvyle 1987).

The timing of downstream migration differs based on distance from the Sargasso Sea, presumably so that all silver eels along the North American coast arrive at the spawning grounds in late winter or early spring. The earliest migrants are in the uppermost reaches of the Great Lakes basin, beginning migration in early to mid-summer (Verreault et al. 2003). Timing of migration in coastal areas of the northeastern U.S. is typically in the fall (Winn et al. 1975; Krueger and Oliveira 1997) and in the southeastern U.S. during winter (Facey and Helfman 1985). Although most migration occurs during late summer to early winter, spring migration has not been document for American Eels. Spring migrations have been documented in several systems for the European Eel (A. anguilla) which follows a similar migration pattern as the American Eel (Cullen and McCarthy 2003; Aarestrup et al. 2008; Calles et al. 2010; Reckordt et al. 2014). One possible explanation for spring migrations in the European Eel is that individuals may be migrating in a multi-year step-wise progression to arrive at the coast and spawning grounds. An alternative explanation for spring migrations may be the result of delays at impounded rivers where escapement is made difficult or impossible for silver eels during their migration season because of water management schedules. If spring runs of silver eels are a 
result of migratory delays, then eels would not be able to access the spawning grounds during the appropriate spawning period and most likely not contribute to the spawning stock (Acou et al. 2008).

During the migration season in freshwater systems, downstream migration may be related to environmental variables. American Eel downstream migrations are typically intermittent, with pulses of migrating eels interspersed with periods of no migration activity. In these systems, punctuated migration patterns may be correlated with several environmental variables. Few studies have evaluated the relationship between environmental variables and downstream migration for the American Eel (eg. Euston et al. 1998; Haro 2003), but many studies have been conducted on other Anguilla species, particularly the European Eel. Most studies indicate that rainfall or increases in river discharge are likely key factors associated with silver eel migration (Behrmann-Godel and Eckmann 2003; Cullen and McCarthy 2003; Durif et al. 2003; Haro 2003; Wantene et al. 2003; Acou et al. 2008; Bruijs et al. 2009; Travade et al. 2013). However, other studies have recorded silver eel migrations at times not associated with increases in flow or with rain events (Euston et al. 1998; Carr and Whoriskey 2008). Water temperature also seems to be an important predictive variable in silver eel migration, with sharp declines in water temperatures late in the year initiating downstream migrations (Euston et al. 1998; Cullen and McCarthy 2003; Durif et al. 2003; Acou et al. 2008; Reckordt et al. 2014). The darker phases of the moon have been correlated in some studies to silver eel migrations (Euston et al. 1998), but other studies show large pulses of eels migrating during a full or nearly-full moon (Behrmann-Godel and Eckmann 2003; Reckordt et al. 2014). Regardless of correlation with environmental variables, silver eel migration occurs almost exclusively at night. 
Peak migrations occur for several hours after the onset of darkness (Euston et al. 1998; Bruijs et al. 2009), with continued steady movement through dark hours (Durif et al. 2003; Wantene et al. 2003; Calles et al. 2010).

Although silver eel migrations have been correlated with environmental variables, researchers have had a difficult time using environmental variables to predict the timing of silver eel migrations in rivers. Eel migrations are variable in nature and change from one year to the next within the same systems, so that predicting movement has been difficult ( $\vee \varnothing l l e s t a d$ et al. 1986; Reckordt et al. 2014). Models using environmental variables to describe silver eel migrations have been able to explain between $20 \%-60 \%$ of the variability in silver eel migration patterns (Euston et al. 1997; Cullen and McCarthy 2003; Reckordt et al. 2014). The inability to use environmental variables to successfully predict eel migrations may result from trying to predict migrations in highly impacted rivers, with multiple dams that may slow or stop migration. Dams that have control of water flow in a river and can obscure the effects of environmental variables on silver eel migrations (Carr and Whoriskey 2008). Also, another issue is that individuals may initiate migrations at different times of the year with different combinations of environmental variables, leading to low predictability in current modeling efforts (Reckordt et al. 2014).

Impact of Dams on Eel Distribution and Life History Traits:

Despite diverse habitat use and life history strategies, the American Eel has experienced population decline (ASMFC 2012) and is currently being considered for listing under the Endangered Species Act in the U.S. (USFWS 2011). The decline in the American Eel population is 
likely associated with a number of factors, including habitat loss and fragmentation, commercial fishing, pollution, turbine mortality, contamination, parasites, and climate change (Verreault et al. 2004; ASMFC 2012).

Habitat loss and fragmentation due to dams is likely an important factor in the decline of the American Eel population. The historic freshwater range of American Eel included all the tributaries to the Atlantic Coast of the U.S. and Canada, the St. Lawrence River and Lake Ontario, and the Mississippi River basin (Facey and Van Den Avyle 1987). There are over 15,000 dams along the U.S. Atlantic Coast and in the Great Lakes basin that can hinder or prevent both upstream and downstream American Eel migrations (Busch et al. 1998). Dam construction has reduced or restricted access to $84 \%$ of historic American Eel habitat. The St. Lawrence River is the largest watershed within the geographic range and constitutes 19\% of the American Eel's historical distribution. The St. Lawrence watershed has at least 8,411 dams higher than 2.5m, restricting access to over $12,000 \mathrm{~km}^{2}$ of historic habitat. In addition, the St. Lawrence basin has 151 hydroelectric plants that further impact migrating American Eels (Verreault et al. 2004). The Chesapeake Bay is the third largest watershed, besides the St. Lawrence and Mississippi rivers, within the American Eel's geographic distribution. The Chesapeake Bay and tributaries are also central to the American Eel's distribution and have a high level of eel harvest, second only to Canada (DFO 2010; ASMFC 2012). Within the Chesapeake Bay watershed, $13 \%$ of 133,082 stream kilometers are not dammed and only $12 \%$ of the 28,140 stream kilometers in the Potomac River basin are free-flowing. The Chesapeake Bay watershed has at least 56 hydroelectric dams, 12 of which are in the Potomac River basin. The majority of dams in the 
Chesapeake Bay watershed are more than $3 \mathrm{~m}$ high, including $98 \%$ of dams in the Potomac River basin (Busch et al. 1998).

Dams can limit or preclude eels from occupying historical freshwater habitats. For upstream migration, dams can range from essentially no barrier to a complete barrier (Couillard et al. 1992; White and Knights 1997; Solomon and Beach 2004). Elvers and yellow eels have the ability to climb over or around dams along wet surfaces, so some low head dams may be essentially no barrier to upstream migration. However large dams can be a partial or complete barrier to upstream access. A study of a dam removal project on the Rappahannock River in Virginia showed increased numbers and a smaller size at arrival for eels in areas over $150 \mathrm{~km}$ upstream from the project, indicating that the dam was a partial barrier to migration that impacted both quantity and size of migrants accessing the upstream reaches of the river (Hitt et al. 2012). In the Hudson River, eel densities in upstream areas were reduced by a factor of 10 by dams and the condition of eels above dams in the watershed was better than eels below dams (Machut et al. 2007). In Connecticut and Maryland tributaries, eel densities were significantly higher below dams than in upstream reaches (Levesque and Whitworth 1987; Wiley et al. 2004). In the Susquehanna River, the largest tributary to the U.S. Atlantic Coast, American Eels have been entirely precluded from all but the lowermost $16 \mathrm{~km}$ of the river because of the $29 \mathrm{~m}$ high Conowingo Dam (Dittman et al. 2010).

Dams impact eel populations by altering natural eel densities which impacts sex ratio, and size and age at maturity for eels in a watershed. In the Hudson River, dams reduced upstream eel densities and females were eight times more abundant than males above the first barriers on tributaries (Machut et al. 2007). Age and total length of eels in the Hudson River 
were also higher above barriers; with total length increasing with increasing distance upstream (Machut et al. 2007). A similar pattern with increasing distance coupled with larger and older female eels was also observed in the Thames/Connecticut River (Levesque and Whitworth 1987). The large body size of mature females in upstream areas results in higher individual fecundity (Barbin and McCleave 1997). The St. Lawrence River typically produces large female eels and the construction of dams in the watershed is thought to reduce the total potential eel production in the watershed by about 800,000 large female eels annually (Verreault et al. 2004). The loss of access to upstream habitats may be shifting the American Eel population to a more male-dominated population and females being smaller at the time of maturity, reducing the overall egg production of the population when they arrive at the spawning grounds.

Dams also concentrate small migrating eels in high densities and likely subject individuals to increased competition, reduced food availability, and lower growth rates than if they were allowed to move into upstream areas (Beentjes and Jellyman 2003; Graynoth and Taylor 2004). Although predation on small eels is likely very high at the base of dams, as eels are found in the diet of many piscivorous species (Buckel and Conover 1997; Griffin and Margraf 2003; Walter and Austin 2003; Bevacqua et al. 2011), there are no studies documenting the extent of such impacts. For juvenile eels residing in lower river sections, dams can also preclude seasonal migrations to estuaries during the summer months (Cairns et al. 2004).

Dams can alter ecosystem function by precluding access to historical eel habitat. In many coastal streams with unrestricted access to habitat, eels are the most abundant fish species present (Odgen 1970; Machut et al. 2007). In upstream areas, female eels can reach 
very large sizes (>1m) and can occupy the niche of top predator. At large sizes, eels are piscivorous, consuming both fish and crustaceans in small streams (Ogden 1970; Facy and LaBar 1981). The loss of this primary predator has cascading impacts on community structure in freshwater streams (Dorner and Benndorf 2003). The American Eel can also serve as an important host species for some species of freshwater mussels, and eel-dependent mussel populations have been depleted in rivers absent of American Eels (Lellis et al. 2013).

\section{Dams and Downstream Eel Migration:}

Dams can delay or prohibit downstream migrations, ultimately impacting spawning success of American Eels. After American Eels complete their growth phase, they begin downstream migrations to ultimately end up at the Sargasso Sea to spawn. Within a geographic area, downstream migrations occur over a distinct time period so that American Eels arrive at the spawning grounds in the Sargasso Sea during late winter. Some dams cause migratory delays which cause American Eels to risk traveling downstream at a point too late in the year to reach the spawning grounds at an appropriate time or alternately delaying migration for a year in order to reach the spawning grounds during the spawning season. If eels arrive at the Sargasso Sea outside of the spawning season, there could be lack of spawning success (Acou et al. 2008) or increased pre-spawn mortality. Although it appears that maturation (silvering) in eels may be suspended or reversed in the early stages (Svedäng and Wickström 1997), it is unclear how these reversals would impact spawning success.

Both hydroelectric and non-hydroelectric dams can cause delays in downstream migration of silver eels. Dams can cause migratory delays through controlled water releases or 
through operation that may alter the river's flow pattern. At dams where water release is intermittent and completely controlled, eels may not be able to migrate out of impoundments at their preferred fall migration time (Feunteun et al. 2000). At dams where water release is more frequent and occurs during the migration season, there still can be migratory delays as eels search for a way to pass the structure and move downstream. Delays at dams can be as little as several minutes to several weeks or longer for migrating eels (Acou et al. 2008; Calles et al. 2010). The longer the delay time, the more likely spawning success will be negatively impacted.

Hydroelectric turbine mortality is a factor impacting the spawning migration to the Sargasso Sea. The elongate body of the eel makes them highly susceptible to blade strikes by turbines, and likelihood of turbine mortality increases with increasing eel length (Jansen et al. 2007; Calles et al. 2010). Turbine specific mortality rates vary widely and are dependent on the project turbine types, configuration, and operation. For example, Kaplan turbines typically have higher mortality rates than Francis turbines for eels (24\% vs. 16\%, Desrochers 1995).

Documented mortality rates for silver eels passing through turbines range from $6 \%$ to $100 \%$ (Jansen et al. 2007; Carr and Whoriskey 2008; Bruijs et al. 2009; Calles et al. 2010; Pedersen et al. 2012; Buysse et al. 2014). Previous studies on the Shenandoah River at the Luray Dam (Francis turbines) found a relatively low mortality rate (9\%) for American Eels passing through turbines (Euston et al. 1998).

Although turbine mortality may be avoided by not allowing eels to pass through turbines, diverting eels to other passage routes at hydroelectric projects does not guarantee survival. Eels can suffer impact mortality when passing over a dam spillway when falling from 
high elevations or landing on hard surfaces. A study on silver eels in Sweden found a spill mortality of $17 \%$ at a hydroelectric project (Calles et al. 2010). Bypass pipes are also used to pass eels through dams, and these pipes have been documented to cause significant mortality through pressure changes and abrasions (Watene and Boubée 2005). In Europe, narrow trash rack spacing has been required to prevent access to turbines for eels, however high flows near the trash racks have resulted in high levels of impingement which can be an additional source of mortality (Calles et al. 2010).

Migration past multiple dams results in cumulative migratory delays and mortality of downstream migrating eels (Piper et al. 2013). Many rivers have multiple dams and associated hydroelectric projects (i.e. Shenandoah, Potomac, Susquehanna, Merrimack and Connecticut rivers). In the Kennebec River, Maine, there are 22 hydroelectric projects in the $8,300 \mathrm{~km}^{2}$ watershed. Modeling results estimating a relatively high survival rate of $90 \%$ at each of the dams would result in a cumulative survival of $40 \%$ of the downstream migrants leaving the river (McCleave 2001). On the River Mosel in Germany, 77\% survival at each dam would result in overall escapement of silver eel from the system at $2 \%$ of the starting population (BehrmannGodel and Eckmann 2003). For the Shenandoah River, assuming a relatively high survival of $90 \%$ at all five hydroelectric dams, eels leaving the river upstream from the uppermost dam (Shenandoah Dam) would result in a cumulative survival of less than $60 \%$. If survival were only $80 \%$ at each of these dams, cumulative survival coming out of the Shenandoah River would be only $33 \%$. Without adequate protection for downstream migrating eels, it may be difficult to justify efforts to allow them access to upstream habitats that are severely impacted by dam operations (Sweka et al. 2014). 
Methods to Mediate Impacts by Dams:

Several methods have been implemented to mediate the impacts of dams on upstream eel migration. The most effective method is dam removal (Hitt et al. 2012). However dam removal is not practical or possible in many cases so methods for moving eels upstream past dams have been developed. Traditional ramp-like fishways, such as denil and steepass ladders as well as fish lifts installed for salmonids or alosids have not been effective in moving eels upstream (ASMFC 2013). Alternatively, eel ladders have been designed for dams to facilitate upstream migration. There are many different types of eel ladders in use and their structure and climbing substrate is site specific to the size of the dam to be traversed and the size of the eels migrating at the site. Eel ladders include inclined or vertical pipes lined with climbing substrate, bypass channels, and ramps with brush, mat or peg substrates (Knights and White 1998). Compared to traditional fish passage structures, eel ladders can be relatively inexpensive, seasonally implemented, and require relatively little water to operate.

Eel ladders have been successful in providing access past dams to historical freshwater habitat. At a small mill dam in the Hudson River, eel densities below the dam were reduced by $40 \%$ in the first year after installation of an eel ladder (Schmidt et al. 2009). An eel ladder on the St. Lawrence River passed over 3 million eels within the first four years of operation (Whitfield and Kolenosky 1978). On the Shenandoah River, there have been three eel ladders constructed with some success in passing American Eels upstream (Hildebrand 2005; Welsh and Liller 2013). At dams where eel ladders are not feasible, or in rivers with multiple dams, trap and transport has been implemented to move eels around multiple barriers and into the uppermost reaches 
of watersheds. Trap and transport has been used for decades in both New Zealand and Europe (Boubée et al. 2003; McCarthy et al. 2008), and more recently on the Susquehanna River in Maryland (SRAFRC 2013).

Downstream eel passage can be aided using several methods, including dam removal, spill, bypass channels, trap and transport, and through-turbine passage. Like upstream passage, dam removal is the most protective of downstream migrants, but again, removal of dams is not practical or feasible in many situations. In most situations, particularly at non-hydroelectric dams, the most common downstream passage method is via spill. Spill can occur over the dam crest or through spill gates of both hydroelectric and non-hydroelectric dams. Depending on the conditions of the dam, spill can be the safest method to pass eels downstream, and may be used by hydroelectric dams to reduce the turbine mortality associated with passing eels through turbines. To best protect eels by passing them downstream through spill, the landing area should be modified so that eels are not impacting hard surfaces during their fall and water releases through gates should be done in a way to eliminate mortality from pressure changes (Watene and Boubée 2005; Calles et al. 2010).

Sluiceways and bypass channels can also be used in both hydroelectric and nonhydroelectric dams to pass eels downstream. Eels can be diverted to sluiceways or bypass channels using guidance systems to safely pass them downstream of a dam. Both surface and bottom bypasses have been effective, having a greater than $50 \%$ efficiency in combination with a guidance system (Gossett et al. 2005). With bypass facilities, there is a preference for bottom bypass systems since eels travel at varying depths and can change depth rapidly, making surface orientated bypasses less effective for eels compared to surface orientated alosids and 
salmonids (Haro et al. 2000; Durif et al. 2003). Pipes have also been used for bypass structures to pass eels downstream. However, pipes may cause high mortality rates due to abrasion, and also may not reduce migratory delay if eels do not readily use the pipe to migrate downstream (Legault et al. 2003).

Bypass structures and sluiceways are more effective when used in combination with guidance devices (Richkus and Whalen 1999). Eels, which have a tendency to travel in proportion with flow, often swim where the largest proportion of water is traveling past the dam (Jansen et al. 2007). Since bypass facilities generally discharge a small proportion of the volume of water passing a dam, eels may have difficulty finding the bypass or sluice to safely travel downstream (Carr and Whoriskey 2008; Travade et al. 2010; Pedersen et al. 2012). Guidance devices consist of physical or behavioral barriers that deter or prevent eel migration through unwanted locations (i.e. turbines) and toward a safe passage method, such as a bypass channel or sluice. Physical barriers generally consist of screening, angled bar racks, or louvers. Angled bar racks and screening are more effective when they have very narrow spacing (i.e. $50 \mathrm{~mm}$ ), are placed at a very small angle (i.e. $15^{\circ}$ ), and are full-depth bypasses (Amaral et al. 2003). Physical barriers however are likely only feasible options for small projects due to the high cost of the large screening infrastructure necessary at large dams coupled with the large proportion of water needed to make the bypass facility attractive to eels. The required bypass flow could reduce the amount of water available for hydroelectric generation (Richkus and Dixon 2003). Another factor related to the success of a guidance device is that approach velocities must be low (i.e. less than $1 \mathrm{~m} / \mathrm{s}$ ) so that eels are not impinged onto screens and racks causing additional mortality (Adam and Schwevers 1997). Impingement mortality has been 
found to be higher than $50 \%$ at locations with narrow bar rack spacing and high approach velocities (Calles et al. 2010). Besides physical barriers, behavioral barriers, including light, sound, water jets, bubble curtains, and electrical fields have been attempted with variable success in directing eel movement (Richkus and Dixon 2003). Although light has the most promise among behavioral barriers, its success can be confounded by changes in river flow and turbidity which can drastically reduce its effectiveness (Richkus and Dixon 2003).

Trap and transport is another method of moving silver eels downstream past dams. Like upstream trap and transport, silver eel trap and transport has been used in basins with multiple dams to increase escapement of adult migrating eels in both Europe and New Zealand (Boubée et al. 2003; Klein Breteler et al. 2007; McCarthy et al. 2008). This method could be very effective in protecting some portion of downstream migrating mature silver eels, particularly in rivers with multiple hydroelectric projects (Richkus and Dixon 2003). However, trap efficiencies are relatively low (range 10\%-20\%, McCarthy et al. 2008; McCarthy et al. 2014) therefore providing a safe downstream migration route for silver eels at dams would still be necessary in rivers with trap and transport activities.

The final method for downstream migration is through turbines at hydroelectric facilities. At hydroelectric dams, downstream passage occurs frequently through the turbines, resulting in some level of turbine mortality. To reduce turbine mortality, several methods have been implemented to protect migrating silver eels, including downstream bypass structures (discussed above), installation of fish-friendly turbines, modified turbine operations, and turbine shutdowns coupled with controlled spill. Fish friendly turbines are still experimental in hydroelectric operations. They are different in size and function than traditional turbines and it 
is difficult and expensive to retrofit existing traditional turbines with fish friendly turbines into hydroelectric plants (i.e. EPRI 2011; New England Hydropower 2012).

Modified turbine operation to a fish-friendly mode has been attempted in the River Mosel in Germany and has had some success in protecting eels. The fish-friendly mode includes changes in drop height and reducing flow through the turbines to reduce modeled mortality rates for eels. Turbine operation in the fish-friendly mode resulted in a significant loss of power generation (Becker et al. 2009). Fish-friendly turbine operation may be more attractive to hydroelectric operators if the timing of silver eel migration could be predicted to limit the amount of time spent in the fish friendly mode. Efforts to predict the timing of eel migration on the River Mosel has been difficult, so it is unclear if the fish-friendly turbine operation is a feasible option to protect silver eels (Becker et al. 2009).

Complete turbine shutdown coupled with spill during the downstream migration period has been implemented to protect migrating silver eels (i.e. Maine Federal Energy Regulatory Commission project numbers $2897,2932,2941,2931,2942,2528)$. Assuming that the spill causes little or no mortality, silver eel survival during shutdown periods can reach $100 \%$ when passing by hydroelectric dams. However as with fish-friendly turbines, the loss of revenue from lack of power generation during shutdowns can be substantial unless shutdowns can be limited to short periods of time (Boubée et al. 2003; Richkus and Dixon 2003). At run-of-river dams, it is more critical to conduct turbine shutdowns during periods of relatively low flow. Eels tend to travel in the water column in proportion to flow, so at low flow conditions, a higher proportion of water and eels will be passing through the turbines, increasing likelihood of mortality. During 
high flow events, a greater proportion of water and eels will be spilling over the dam, increasing their chance of survival (Boubée and Williams 2006; Jansen et al. 2007).

Although turbine shutdowns can be very effective in protecting migrating silver eels, predicting when silver eels will be migrating has been difficult. Some turbine shutdowns have been done based on time of day and time of year, shutting down in the evenings for a period of time during the suspected fall migration period (i.e. 105 FERC 961,013 , Shenandoah River, this study). Haro et al. 2003 suggested that an adequate shutdown practice would be to suspend turbine operation on the calendar days that encompassed the middle $50 \%$ of the run dates and during that time only shutdown at night on days when it rained. An alternative to conducting turbine shutdowns on calendar dates is to link shutdowns to environmental factors (discussed above). Most studies indicate that river discharge, water temperature, and lunar phase correlate with migration (Haraldstad et al. 1985; Vøllestad et al. 1986; Durif et al. 2003; Reckordt et al. 2014). However, eel migrations are highly variable and using environmental variables to predict eel migration has had limited success (Vøllestad et al. 1986; Reckordt et al. 2014).

Summary-Benefits of Dam Mediation for Eel Migrations:

Dams can impact upstream and downstream migrations for the catadromous American Eel. Allowing access to historical upstream habitat for eels will restore natural ecosystem functions by restoring a top predator to the food web and providing a host fish for some mussel species. Providing upstream access will reduce densities of eels that are restricted by barriers in their upstream migrations, thereby increasing survival through reduced predation and 
competition between conspecifics. In addition, in upriver habitats, a higher proportion of larger and more fecund female eels will be produced. In order to protect these highly fecund females leaving the upstream reaches of river systems, migratory delays and mortality on silver eels should be reduced or eliminated. Producing and protecting these highly fecund females has the potential to benefit the population of American Eel, which is suffering from a decline in recent decades and is currently under consideration for listing under the Endangered Species Act in the United States.

\section{Shenandoah River Eel Project:}

This literature review evaluates the impacts of dams on American Eel migrations in tributaries to the Atlantic Coast. Dams create upstream and downstream barriers to migration for American Eels and can potentially have an impact on their life history traits and reproductive success. In addition, ecosystem function is impacted by reduced or eliminated access for American Eels to upstream habitats. This literature review supports my dissertation research that evaluated the impacts of five hydroelectric dams on the downstream migration of mature American Eels in the Shenandoah River in Virginia and West Virginia. In the study, I considered how the dams may impact the timing and delays of downstream migration, if environmental variables may be related to downstream migration events, how well turbine shutdown periods protected downstream migrants, and if the current shutdown period was appropriate for protecting migrating American Eels. 


\section{References:}

Aarestrup, K., E. B. Thorstad, A. Koed, N. Jepsen, J. C. Svendensen, M. I. Pedersen, C. Skov, and F. Økland. 2008. Survival and behavior of European silver eel in late freshwater and early marine phase during spring migration. Fisheries Management and Ecology 15:435-440.

Acou, A., P. Laffaille, A. Legault, and E. Feunteun. 2008. Migration pattern of silver eel (Anguilla anguilla, L.) in an obstructed river system. Ecology of Freshwater Fish 17:432-442.

Adam, B. and D. U. Schwevers. 1997. Behavioral surveys of eels (Anguilla anguilla) migrating downstream under laboratory conditions. 36320 Kirtorf-Wahlen, Germany: Institute of Applied Ecology.

Amaral, S. V., F. C. Winchell, B. J. McMahon, D. A. Dixon. 2003. Evaluation of angled bar racks and louvers for guiding silver phase American Eels. Pages 367-376 In: D. A. Dixon (editor), Biology, management, and protection of catadromous eels. American Fisheries Society, Symposium 33, Bethesda, Maryland, 388 p.

Atlantic States Marine Fisheries Commission (ASMFC). 2012. American Eel benchmark stock assessment. Stock Assessment Report No. 12-01 of the Atlantic States Marine Fisheries Commission. Arlington, Virginia 338 p.

Atlantic States Marine Fisheries Commission (ASMFC). 2013. Proceedings of a workshop on American Eel passage technologies. Special Report No. 90 of the Atlantic States Marine Fisheries Commission. Arlington, Virginia 32p.

Avise, J. C., G. S. Helfman, N. C. Saunders, and L. S. Hales. 1986. Mitochondrial DNA differentiation in North Atlantic eels: population genetic consequences of an unusual life 
history pattern. Proceedings of the National Academy of Sciences of the United States of America 83(12):4350-4354.

Barbin, G. P., and J. D. McCleave. 1997. Fecundity of the American Eel Anguilla rostrata at $45^{\circ} \mathrm{N}$ in Maine, U.S.A. Journal of Fish Biology 51:840-847.

Becker, B., F. Notermanns, C. Reuter, and H. Schuttrumpf. 2009. Development of a fish-friendly turbine-operation mode in run-of-river hydropower plants on the River Mosel. Hydrologie und Wasserbewirtschaftung 53:4-12.

Beentjes, M. P., and D. J. Jellyman. 2003. Enhanced growth of Longfin Eel, Anguilla dieffenbachii, transplanted into Lake Hawea, a high-country lake in South Island, New Zealand. New Zealand Journal of Marine and Freshwater Research 37:1-11.

Behrmann-Godel, J., and R. Eckmann. 2003. A preliminary telemetry study of the migration of silver European Eel (Anguilla anguilla L.) in the River Mosel, Germany. Ecology of Freshwater Fish 12:196-202.

Bevacqua, D., M. Andrello, P. Meli, S. Vincenzi, G .A. De Leo, and A. J. Crivelli. Density dependent and inter-specific interactions affecting European Eel settlement in freshwater habitats. Hydrobiologia 671:259-265.

Boubée, J., B. Chisnall, E. Watene, and E. Williams. 2003. Enhancement and management of eel fisheries affected by hydroelectric dams in New Zealand. Pages 191-205 In: D. A. Dixon (editor), Biology, management, and protection of catadromous eels. American Fisheries Society, Symposium 33, Bethesda, Maryland, 388 p.

Boubée, J. A. T., and E. K. Williams. 2006. Downstream passage of silver eels at a small hydroelectric facility. Fisheries Management and Ecology 13:165-176. 
Bruijs, M. C. M., R. H. Hadderingh, U. Schwevers, B. Adam, U. Dumont, and H. V. Winter. 2009. Managing human impact on downstream migrating European Eel in the River Meuse. Pages 381-390 In: J. M. Casselman and D. K. Cairns (editors), Eels at the edge: science, status, and conservation concerns. American Fisheries Society, Symposium 58, Bethesda, Maryland, $449 \mathrm{p}$.

Buckel, J. A. and D. O. Conover. 1997. Movements, feeding periods, and daily ration of piscivorous young-of-the-year bluefish, Pomatomus saltatrix, in the Hudson River estuary. Fishery Bulletin 95:665-679.

Busch, W. -D. N., S. J. Lary, and C. M. Castiglione. 1998. Evaluating stream habitat for diadromous fish in Atlantic Coast watersheds: a preliminary assessment. Habitat Hotline Atlantic, Atlantic States Marine Fisheries Commission. 27:1-3.

Buysse, D., A. M. Mouton, M. Stevens, T. Van Den Neucker, J. and Coeck. 2014. Mortality of European eel after downstream migration through two types of pumping stations. Fisheries Management and Ecology 21:13-21.

Cairns, D. K., J. C. Shiao, Y. lizuka, W. -N. Tzeng, and C. D. MacPherson. 2004. Movement patterns of American Eel in an impounded watercourse, as indicated by otolith microchemistry. North American Journal of Fisheries Management 24:452-458.

Cairns, D. K., D. A. Secor, W. E. Morrison, and J. A. Hallett. 2009. Salinity-linked growth in anguillid eels and the paradox of temperate-zone catadromy. Journal of Fish Biology 74:2094-2114. 
Calles, O., I. C. Olsson, C. Comoglio, P. S. Kemp, L. Blunden, M. Schmitz, and L. A. Greenberg. 2010. Size-dependent mortality of migratory silver eels at a hydropower plant, and implications for escapement to the sea. Freshwater Biology 55:2167-2180.

Carr, J. W., and F. G. Whoriskey. 2008. Migration of silver American Eels past a hydroelectric dam and through a coastal zone. Fisheries Management and Ecology 15:393-400.

Côté, C. L., P. -A. Gagnaire, V. Bourret, G. Verreault, M. Castonguay, and L. Bernatchez. 2013. Population genetics of the American Eel (Anguilla rostrata): $\mathrm{F}_{\mathrm{st}}=0$ and North Atlantic Oscillation effects on demographic fluctuation of a panmictic species. Molecular Ecology 22:1763-1776.

Couillard, C. M., S. Leclerc, H. Gilbert, M. Greiner, and C. Mitchell. 1992. Localisation des preincipaux obstacles a la migration des anguilles le long de fleuve Saint-Laurent. Technical report. Peches et Oceans Canada Inst. Mauriece Lamontagne. 28 p.

Cullen, P., and T. K. McCarthy. 2003. Hydrometric and meteorological factors affecting the seaward migration of silver eels (Anguilla anguilla, L.) in the lower River Shannon. Environmental Biology of Fishes 67:349-357.

DeLeo, G. A., and M. Gatto. 1996. Trends in vital rates of the European Eel: evidence for density dependence. Ecological Applications 6:1281-1294.

Department of Fisheries and Oceans Canada (DFO). 2010. Status of American Eel and progress on achieving management goals. DFO Canada Science Advisory Secretariat. Science Advisory Report 2010/062. 
Desrochers, D. 1995. Suivi de la migration de l'anguille d'Amérique (Anguilla rostrata) au comlplexe, Beauharnois. 1994. [par]MILIEU \& Associâtes Inc., [pour] le Milieu naturel, vice-présidence Environment, Hydro-Quebec, 107 p.

Dittman, D. E., L. S. Machut, and J. H. Johnson. 2010. American Eels: data assimilation and management options for New York inland waters. Final Report for C005548, Comprehensive study of the American Eel to State Wildlife Grant NYSDEC, Bureau of Wildlife, Albany, NY. 36 p.

Dorner, H., and J. Benndorf. 2003. Piscivory by large eels on young-of-the-year fishes: its potential as a biomanipulation tool. Journal of Fish Biology 62:491-494.

Durif, C., P. Elie, C. Gosset, J. Rives, and F. Travade. 2003. Behavioral study of downstream migrating eels by radio-telemetry at a small hydroelectric power plant. Pages 343-356 In: D. A. Dixon (editor), Biology, management, and protection of catadromous eels. American Fisheries Society, Symposium 33, Bethesda, Maryland, 388 p.

Dutil, J. -D., M. Besner, and S. D. McCormick. 1987. Osmoregulatory and ionoregulatory changes and associated mortalities during the transition of maturing American eels to a marine environment. Pages 175-190 In: M. J. Dadswell, R. J. Klauda, C. M. Moffitt, and R. L. Saunders, R. A. Rulifson and J. E. Cooper (editors) Common strategies of anadromous and catadromous fishes, American Fisheries Society Symposium 1. Bethesda, Maryland, $561 \mathrm{p}$.

Dutil, J. -D., M. Michaud, and A. Giroux. 1989. Seasonal and diel patterns of stream invasion by American Eels (Anguilla rostrata) in the northern Gulf of St. Lawrence. Canadian Journal of Zoology 67:182-188. 
Electric Power Research Institute (EPRI). 2011. Evaluation of fish injury and mortality associated with hydrokinetic turbines. Prepared by Alden Research Laboratory, Inc. Technical Report 1024569.

Euston, E. T., D. E. Royer, and C. L. Simons. 1997. Relationship of emigration of silver American Eels (Anguilla rostrata) to environmental variables at a low head hydro station held in Atlanta, Georgia. In: D.J. Mahoney (editor) Proceedings of the International Conference on Hydropower, Reston, VA, Atlanta, GA, American Society of Civil Engineers (ASCE) pages $549-558$.

Euston, E. T., D. E. Royer, and C. L. Simons. 1998. American Eels and hydro plants: clues to eel passage. Hydro Review (August) 17:94-103.

Facey, D. E., and G. S. Helfman. 1985. Reproductive migrations of American Eels in Georgia. Proceedings of the Annual Conference of the Southeastern Association of Fish and Wildlife Agencies 39:132-138.

Facey, D. E., and G. W. LaBar. 1981. Biology of American Eels in Lake Champlain, Vermont. Transactions of the American Fisheries Society 110:396-402.

Facey, D. E., and M. J. Van Den Avyle. 1987. Species profiles: life histories and environmental requirements of coastal fishes and invertebrates (North Atlantic)-American Eel. USFWS Biological Report 82 (11.74). U.S. Army Corps of Engineers, TR EL-82-4. 28 p.

Federal Energy Regulatory Commission (FERC). 2003. Order issuing subsequent license S.D. Warren Company for Presumpscot River Projects. 105 FERC $₫$ 61,013. 
Feunteun, E., A. Acou, P. Laffaille, and A. Legault. 2000. European Eel (Anguilla anguilla): prediction of spawner escapement from continental population parameters. Canadian Journal of Fisheries and Aquatic Sciences 57:1627-1635.

Goodwin, K. R. and P. L. Angermeier. 2003. Demographic characteristics of American Eel in the Potomac River drainage, Virginia. Transactions of the American Fisheries Society 132:524-535.

Gosset, C., F. Travade, C. Durif, J. Rives and P. Elie. 2005. Tests of two types of bypass for downstream migration of eels at a small hydroelectric power plant. River Research and Applications 21:1095-1105.

Graynoth, E. and M. J. Taylor. 2004. Growth of juvenile eels (Anguilla spp.) in lowland streams in New Zealand. Fisheries Research 66:95-106.

Griffin, J. C., and F. J. Margraf. 2003. The diet of Chesapeake Bay striped bass in the late 1950s. Fisheries Management and Ecology 10:323-328.

Haraldstad, Ø., L. A. Völlestad, and B. Jonsson. 1985. Descent of European silver eels, Anguilla anguilla L., in a Norwegian watercourse. Journal of Fish Biology 26:37-41.

Haro, A. 2003. Downstream migration of silver-phase anquillid eels. Pages 215-222 In: K. Aida, K. Tsukamoto, and K. Yamauchi (editors), Eel biology. Springer-Verlag, New York. 497 p. Haro, A. J., and W. H. Krueger. 1991. Pigmentation, otolith rings, and upstream migration of juvenile American Eels (Anguilla rostrata) in a coastal Rhode Island stream. Canadian Journal of Zoology 69:812-814.

Haro, A., T. Castro-Santos, and J. Boubée. 2000. Behavior and passage of silver-phase American Eels, Anguilla rostrata (LeSueur), at a small hydroelectric facility. Dana 12:33-42. 
Haro, A., T. Castro-Santos, K. Whalen, G. Wippelhauser, and L. McLaughlin. 2003. Simulated effects of hydroelectric project regulation on mortality of American Eels. Pages 357-365 In: D. A. Dixon (editor), Biology, management, and protection of catadromous eels. American Fisheries Society, Symposium 33, Bethesda, Maryland, 388 p.

Harrell, R. M., and H. A. Loyacano. 1982. Age, growth and sex ratio of the American Eel in the Cooper River, South Carolina. Proceedings of the Annual Conference of the Southeastern Association of Fish and Wildlife Agencies 34:349-359.

Helfman, G. S., D. E. Facey, L. S. Hales, Jr., and E. L. Bozeman, Jr. 1987. Reproductive ecology of the American eel. Pages 42-56 In: M. J. Dadswell, R. J. Klauda, C. M. Moffitt, R. L. Saunders, R. A. Rulifson and J. E. Cooper (editors) Common strategies of anadromous and catadromous fishes, American Fisheries Society Symposium 1. Bethesda, Maryland, $561 \mathrm{p}$.

Hitt, N. P., S. Eyler, and J. E. B. Wofford. 2012. Dam removal increases American Eel abundance in distant headwater streams. Transactions of the American Fisheries Society 141:11711179.

Jansen, H. A., H. V. Winter, M. C. M. Bruijs, and H. J. G. Polman. 2007. Just go with the flow? Route selection and mortality during downstream migration of silver eels in relation to river discharge. ICES Journal of Marine Science 64:1437-1443.

Jessop, B. M. 1998. Geographic and seasonal variation in biological characteristics of American Eel elvers in the Bay of Fundy area and on the Atlantic coast of Nova Scotia. Canadian Journal of Zoology 76:2171-2185. 
Jessop, B. M. 2000. Estimates of population size and instream mortality rates of American Eel elvers in a Nova Scotia River. Transactions of the American Fisheries Society 129:514526.

Jessop, B. M. 2003. Annual variability in the effects of water temperature, discharge, and tidal state on the migration of American Eel elvers from estuary to river. Pages 3-16 In: D. A. Dixon (editor), Biology, management, and protection of catadromous eels. American Fisheries Society, Symposium 33, Bethesda, Maryland, 388 p.

Jessop, B. M. 2010. Geographic effects on American Eel (Anguilla rostrata) life history characteristics and strategies. Canadian Journal of Fisheries and Aquatic Science 67:326346.

Jessop, B. M., D. K. Cairns, I. Thibault, and W. N.Tzeng. 2008. Life history of American Eel Anguilla rostrata: new insights from otolith microchemistry. Aquatic Biology 1:205-216. Jessop, B. M., J. C. Shiao, and Y. lizuka. 2009. Life history of American Eels from western Newfoundland. Transactions of the American Fisheries Society 138:861-871.

Kleckner, R. C., and J. D. McCleave. 1985. Spatial and temporal distribution of American Eel larvae in relation to North Atlantic Ocean current systems. Dana 4:67-92.

Klein Breteler, J., T. Vriese, J. Borcherding, A. Breukelaar, L. Jörgensen, S. Staas, G. de Laak, and D. Ingendahl. 2007. Assessment of population size and migration routes of silver eel in the River Rhine based on a 2-year combined mark-recapture and telemetry study. ICES Journal of Marine Science 64:1450-1456. 
Knights, B. M., and E. M. White. 1998. Enhancing immigration and recruitment of eels: the use of passes and associated trapping systems. Fisheries Management and Ecology 5:459471.

Krueger, W. H., and K. Oliveira. 1997. Sex, size, and gonad morphology of silver American Eels, Anguilla rostrata. Copeia 1997:415-420.

Krueger, W. H., and K. Oliveira. 1999. Evidence for environmental sex determination in the American Eel, Anguilla rostrata. Environmental Biology of Fishes 55:381-389.

Lamson, H. M., D. K. Cairns, J. -C. Shiao, Y. lizuka, and W. -N. Tzeng. 2009. American Eel, Anguilla rostrata, growth in fresh and salt water: implications for conservation and aquaculture. Fisheries Management and Ecology 16:306-314.

Legault, A., A. Acou, J. Guillouët, and E. Feunteun. 2003. Survey of downstream migration of silver eels through discharge pipe on a reservoir dam. Bulletin Français de la Pêche et de la Protection des Milieux Aquatics 38.

Lellis, W. A., B. S. White, J. C. Cole, C. S. Johnson, E. V. S. Gray, H. S. Galbraith and J. L. Devers. 2013. Newly documented host fishes for the Eastern Elliptio mussel Elliptio complanata. Journal of Fish and Wildlife Management 4:75-85.

Levesque, J. R., and W. R. Whitworth. 1987. Age class distribution and size of American Eel (Anguilla rostrata) in the Shetucket/Thames River, Connecticut. Journal of Freshwater Ecology 4:17-22.

Machut, L. S., K. E. Limburg, R. E. Schmidt, and D. Dittman. 2007. Anthropogenic impacts of American Eel demographics in Hudson River tributaries, New York. Transactions of the American Fisheries Society 136:1699-1713. 
Martin, M. H. 1995. The effects of temperature, river flow, and tidal cycles on the onset of glass eel and elver migration into fresh water in the American Eel. Journal of Fish Biology 46:891-902.

McCarthy, T. K., P. Frankiewicz, P. Cullen, M. Blaszkowski, W. O’Connor, D. Doherty. 2008. Long-term effects of hydropower installations and associated river regulation on River Shannon eel populations: mitigation and management. Hydrobiologia 609:109-124.

McCarthy, T. K., D. Nowak, J. Grennan, A. Bateman, B. Conneely, R. MacNamara. 2014. Spawner escapement of European Eel (Anguilla anguilla) from the River Erne, Ireland. Ecology of Freshwater Fish 23:21-32.

McCleave, J. D. 2001. Simulation of the impact of dams and fishing weirs on reproductive potential of silver-phase American Eels in the Kennebec River basin, Maine.

McCleave, J. D., R. C. Kleckner, and M. Castonguay. 1987. Reproductive sympatry of American and European eels and implications for migration and taxonomy. Pages 286-297 In: M. J. Dadswell, R. J. Klauda, C. M. Moffitt, R. L. Saunders, R. A. Rulifson and J. E. Cooper (editors) Common strategies of anadromous and catadromous fishes, American Fisheries Society Symposium 1. Bethesda, Maryland, 561 p.

McGrath, K. J., J. Bernier, S. Ault, J. -D. Dutil, and K. Reid. 2003. Differentiating downstream migrating American Eels Anguilla rostrata from resident eels in the St. Lawrence River. Pages 315-327 In: D. A. Dixon (editor), Biology, management, and protection of catadromous eels. American Fisheries Society, Symposium 33, Bethesda, Maryland, 388 p. 
Melià, P., D. Bevacqua, A. J. Crivelli, J. Panfili, A. A. De Leo, and M. Gatto. 2006. Sex differentiation of the European Eel in brackish and freshwater environments: a comparative analysis. Journal of Fish Biology 69:1228-1235.

Morrison, W. E., and D. H. Secor. 2003. Demographic attributes of yellow-phase American Eels (Anguilla rostrata) in the Hudson River estuary. Canadian Journal of Fisheries and Aquatic Sciences 60:1487-1501.

Morrison, W. E., D. H. Secor, and P. M. Piccoli. 2003. Estuarine habitat use by Hudson River American Eels as determined by otolith strontium:calcium ratios. Pages 87-99 In: D. A. Dixon (editor), Biology, management, and protection of catadromous eels. American Fisheries Society, Symposium 33, Bethesda, Maryland, 388 p.

New England Hydropower. 2012. Damage to fish by hydro turbines, a new fish friendly approach using the Archimedes screw generator. http://www.nehydropower.com.

Ogden, J.C. 1970. Relative abundance, food habits, and age of the American Eel, Anguilla rostrata (LeSueur), in certain New Jersey streams. Transactions of the American Fisheries Society 99:54-59.

Oliveira, K., and J. D. McCleave. 2000. Variation in population and life history traits of the American Eel, Anguilla rostrata, in four rivers in Maine. Environmental Biology of Fishes 59:141-151.

Overton, A. S., and R. A. Rulifson. 2009. Annual variability in upstream migration of glass eels in a southern USA coastal watershed. Environmental Biology of Fishes 84:29-37.

Owens, S. J., and P. J. Geer. 2003. Size and age of American Eels collected from tributaries of the Virginia portion of Chesapeake Bay. Pages 117-124 In: D. A. Dixon (editor), Biology, 
management, and protection of catadromous eels. American Fisheries Society, Symposium 33, Bethesda, Maryland, 388 p.

Pedersen, M. I., N. Jepsen, K. Aarestrup, A. Koed, S. Pedersen, and F. Økland. 2012. Loss of European silver eel passing a hydropower station. Journal of Applied Ichthyology 28:189-193.

Piper, A. T., R. M. Wright, A. M. Walker, P. S. Kemp. 2013. Escapement, route choice, barrier passage and entrainment of seaward migrating European eel, Anguilla anguilla, within a highly regulated lowland river. Ecological Engineering 57:88-96.

Powles, P. M., and S. M. Warlen. 2002. Recruitment season, size, and age of young American Eels (Anguilla rostrata) entering an estuary near Beaufort, North Carolina. Fisheries Bulletin 100:299-306.

Pujolar, J. M. 2013. Conclusive evidence for panmixia in the American Eel. Molecular Ecology 22:1761-1762.

Reckordt, M., C. Ubl, C. Wagner, J. Frankowski, and M. Dorow. 2014. Downstream migration dynamics of female and male silver eels (Anguilla anguilla L.) in the regulated German lowland Warnow River. Ecology of Freshwater Fish 23:7-20.

Richkus, W. A., and D. A. Dixon. 2003. Review of research and technologies on passage and protection of downstream migrating catadromous eels at hydroelectric facilities. Pages 377-388 In: D. A. Dixon (editor), Biology, management, and protection of catadromous eels. American Fisheries Society, Symposium 33, Bethesda, Maryland, 388 p. 
Richkus, W., and K. Whalen. 1999. American Eel (Anguilla rostrata) scoping study: a literature and data review of life history, stock status, population dynamics, and hydroelectric impacts. EPRI, Palo Alto, CA. TR-111873.

Schmidt, R. E., C. M. O’Reilly, and D. Miller. 2009. Observations of American Eels using an upland passage facility and effects of passage on the population structure. North American Journal of Fisheries Management 29:715-720.

Smogor, R. A., P. L. Angermeier, and C. K. Gaylord. 1995. Distribution and abundance of American Eels in Virginia streams: tests of null models across spatial scales. Transactions of the American Fisheries Society 124:789-803.

Solomon, J., and M. H. Beach. 2004. Fish pass design for eel and elver (Anguilla anguilla). Environment Agency, R\&D Technical Report W2070/TR1. 92 p.

Sorensen, P. W., and M. L. Bianchini. 1986. Environmental correlates of the freshwater migration of elvers of the American Eel in a Rhode Island Brook. Transactions of the American Fisheries Society 115:258-268.

Sullivan, M. C., M. J. Wuenschel, and K. W. Able. 2009. Inter and intra-estuary variability in ingress, condition and settlement of the American Eel Anguilla rostrata: implications for estimating and understanding recruitment. Journal of Fish Biology 74:1949-1969.

Susquehanna River Anadromous Fish Restoration Cooperative (SRAFRC). 2013. Restoration of American Shad to the Susquehanna River. Annual Progress Report 2012. 296 p.

Svedäng, H. and H. Wickström. 1997. Low fat contents in silver eels: indications of insufficient energy stores for migration and gonadal development. Journal of Fish Biology 50:476486. 
Sweka, J. A., S. Eyler, M. J. Millard. 2014. An egg-per-recruit model to evaluate the effects of upstream transport and downstream passage mortality of American Eel in the Susquehanna River. North American Journal of Fisheries Management 34:764-773.

Travade, F., M. Larinier, S. Subra, P. Gomes, E. De-Oliveira. 2010. Behaviour and passage of European silver eels (Anguilla anguilla) at a small hydropower plant during their downstream migration. Knowledge and Management of Aquatic Ecosystems 398 doi: 10.1051/kmae/2010022.

Tremblay, V. 2009. Reproductive strategy of female American Eels among five subpopulations in the St. Lawrence River watershed. Pages 85-102 In: J. M. Casselman and D. K. Cairns (editors), Eels at the edge: science, status, and conservation concerns. American Fisheries Society, Symposium 58, Bethesda, Maryland, 449 p.

U.S. Fish and Wildlife Service (USFWS). 2011. Endangered and threatened wildlife and plants90-day finding on a petition to list the American Eel as threatened. Proposed rules. Federal Register 76:189(29 September 2011):60431-60444.

Verdon, R., and D. Desrochers. 2003. Upstream migratory movements of American Eels Anguilla rostrata between the Beauharnois and Moses-Saunders power dams on the St. Lawrence River. Pages 139-151 In: D. A. Dixon (editor), Biology, management, and protection of catadromous eels. American Fisheries Society, Symposium 33, Bethesda, Maryland, $388 \mathrm{p}$.

Verreault, G., P. Pettigrew, R. Tardif, and G. Pouliot. 2003. The exploitation of the migrating silver American Eel in the St. Lawrence River estuary, Québec, Canada. Pages 225-234 In 
D. A. Dixon (editor), Biology, management, and protection of catadromous eels. American Fisheries Society, Symposium 33, Bethesda, Maryland, 388 p.

Verreault, G., P. Dumont, and Y. Mailhot. 2004. Habitat losses and anthropogenic barriers as a cause of population decline for American Eel (Anguilla rostrata) in the St. Lawrence watershed, Canada. ICES CM2004/S:04.

Vøllestad, L. A., B. Jonsson, N. A. Hvidsten, T. F. Naesje, $\emptyset$. Haraldstad, and J. Ruud-Hansen. 1986. Environmental factors regulating the seaward migration of European silver eels (Anguilla anguilla). Canadian Journal of Fisheries and Aquatic Science 43:1909-1916.

Walter III, J. F., and H. M. Austin. 2003. Diet composition of large striped bass (Morone saxatilis) in the Chesapeake Bay. Fishery Bulletin 101:414-423.

Wang, C. H., and W. -N. Tzeng. 2000. The timing of metamorphosis and growth rates of American and European Eel leptocephali: a mechanism of larval segregative migration. Fisheries Research 46:191-205.

Wantene, E. M., J. A. T. Boubée, and A. Haro. 2003. Downstream movement of mature eels in a hydroelectric reservoir in New Zealand. Pages 195-305 In: D. A. Dixon (editor), Biology, management, and protection of catadromous eels. American Fisheries Society, Symposium 33, Bethesda, Maryland, 388 p.

Wantene, E. M., and J. A. T. Boubée. 2005. Selective opening of hydroelectric dam spillway gates for downstream migrant eels in New Zealand. Fisheries Management and Ecology 12:69-75. 
Welsh, S. A., and H. L. Liller. 2013. Environmental correlates of upstream migration of yellowphase American Eels in the Potomac River drainage. Transactions of the American Fisheries Society 142:483-491.

Wenner, C. A. 1973. Occurrence of American Eel, Anguilla rostrata, in waters overlying the eastern North American continental shelf. Journal of the Fisheries Research Board of Canada 30:1752-1755.

Wenner, C. A., and J. A. Musick. 1974. Fecundity and gonad observations of the American Eel, Anguilla rostrata, migrating from Chesapeake Bay, Virginia. Journal of the Fisheries Research Board of Canada 31:1387-1391.

White, E. M., and B. Knights. 1997. Dynamics of upstream migration of the European Eel Anguilla anguilla (L.), in the rivers Severn and Avon, England, with special reference to the effects of man-made barriers. Fisheries Management and Ecology 4:311-324.

Winn, H. E., W. A. Richkus and L. K. Winn. 1975. Sexual dimorphism and natural movements of the American Eel (Anguilla rostrata) in Rhode Island streams and estuaries. Helgoländer Meeresuntersuchungen 27:156-166.

Whitfield, R. E., and D. P. Kolenosky. 1978. Prototype eel ladder in the St. Lawrence River. The Progressive Fish Culturist 40:152-154.

Wiley, D. J., R. P. Morgan II, and R. H. Hilderbrand. 2004. Relations between physical habitat and American Eel abundance in five river basins in Maryland. Transactions of the American Fisheries Society 133:515-526. 
Chapter 2 - Evidence for spring downstream migrations in silver American Eel (Anguilla rostrata) in the Potomac River basin, USA

\section{Abstract:}

Downstream migrations of silver American Eels Anguilla rostrata are thought to occur during a distinct seasonal period, typically in late summer through early winter, depending on latitude. American Eel migrations in the Potomac River watershed were studied using radio telemetry to determine seasonal and daily timing of downstream passage. Downstream migrations past dams were documented during every month of the year except July, and peak migration occurred during different months for each of the three study years. Over $90 \%$ of passage events occurred from 1 October through 1 May, with 55\% occurring in November and December. Ninety percent of passage events occurred during the hours between sunset and sunrise and $35 \%$ of passage events occurred within three hours of sunset. The speed of downstream migration was similar between Shenandoah River (22 km/d, SE = 3.8), a tributary with multiple hydroelectric dams, and the Potomac River mainstem ( $26 \mathrm{~km} / \mathrm{d}, \mathrm{SE}=6.6$ ) having one lowhead dam in the study reach. This is the first study that has demonstrated substantial downstream migration of American Eels outside the previously assumed fall season for the Mid-Atlantic Region.

Introduction:

The American Eel Anguilla rostrata is found in the coastal waters and freshwater tributaries of the western Atlantic Ocean. The American Eel is a semelparous and catadromous 
species that, after reaching maturity in estuaries and inland waters, migrates to the Sargasso Sea to spawn (Côté et al., 2013). Because of the large geographic range of the American Eel, the distance to travel to the Sargasso Sea is variable, with some individuals traveling over $5500 \mathrm{~km}$ to reach the spawning grounds (Jessop, 2010). Although spawning in the Sargasso Sea has never been observed, spawning is thought to occur from February to April based on collections of leptocephali (larvae) (Kleckner and McCleave, 1985; McCleave et al., 1987).

The timing of downstream migration for mature (silver) American Eels varies by location, presumably based on distances that silver American Eels must travel to reach the Sargasso Sea for the spawning season. In the northern portion of their distribution, silver American Eels begin their downstream migration in late summer through fall (Dutil et al., 1987; Ingraham, 1999; Haro et al., 2003; McGrath et al., 2003; Brown et al., 2009). In the southern portion of their distribution, migration typically occurs through late fall and winter (Harrell and Loyacano, 1982; Facey and Helfman, 1985). Within a geographic region, downstream migrations begin earlier in upstream areas which would allow synchronous departure of mature American Eels from a watershed (McGrath et al., 2003). The timing of both regional and latitudinal migration is critical to ensure that mature American Eels arrive to the spawning grounds in the Sargasso Sea during the spawning season.

This study was conducted, in part, to determine the timing and speed of downstream migration for silver American Eels in the Potomac River basin. Understanding the timing of downstream passage for American Eels is necessary to determine when to implement seasonal protective measures at hydroelectric dams. To determine timing of migration, downstream passage of migrating American Eels was monitored relative to five hydroelectric dams on the 
Shenandoah River in Virginia and West Virginia as well as a dam and an intake structure for municipal water supply on the Potomac River in Maryland.

Methods:

Site Description

The Potomac River is the second largest tributary to the Chesapeake Bay, with a watershed size of $38020 \mathrm{~km}^{2}$. The Shenandoah River is the largest tributary to the Potomac River with a watershed area of $7870 \mathrm{~km}^{2}$. The Shenandoah River discharges into the Potomac River near Harpers Ferry, West Virginia, at river kilometer ( $\mathrm{rkm}) 282$ from the mouth of the Potomac River. There are five hydroelectric dams on the Shenandoah River that are all run-ofriver and range in height from $4.5 \mathrm{~m}$ to $8.7 \mathrm{~m}$ (Figure 1). The distance between the uppermost (Shenandoah) and lowermost (Millville) hydroelectric dam is $195 \mathrm{rkm}$. The Shenandoah River flows an additional $9 \mathrm{~km}$ downstream below the Millville Dam to the confluence with the Potomac River. In the Potomac River there are remains of several dams and weirs, but no intact dams that span the entire width of the Potomac River between the mouth of the Shenandoah River and the Washington Aqueduct Dam located at rkm 206, just upstream of Great Falls, Maryland (Welsh and Liller, 2013). The Washington Aqueduct dam is a low-head dam (4.6 m high) that diverts water into the Washington Aqueduct; a $19 \mathrm{~km}$ long drinking water supply conduit that transports water to the Dalecarlia Reservoir. The Dalecarlia Reservoir is the primary settlement basin for water from the Potomac River before it is diverted into the Dalecarlia Water Treatment Plant. Just downstream of the Washington Aqueduct Dam is Great Falls, a natural $23 \mathrm{~m}$ high waterfall. The next downstream dam from Great Falls on the Potomac 
mainstem is the Little Falls Dam (rkm 192) which is the final dam on the Potomac River. The Little Falls Dam is also a low-head dam (3.7 $\mathrm{m}$ high) with an associated pumping station used for supplying additional water directly into the adjacent Dalecarlia Reservoir.

\section{Fish Collection and Tagging and Monitoring}

American Eels were collected in the Shenandoah River watershed at various locations upstream of the Luray Dam between September and December 2007-2009 (Figure 1). Radio tags (Model F1835 - 18 month or F1830 - 4.5 month, Advanced Telemetry Systems, Inc., MN) were surgically implanted into 145 mature (silver) and large immature (yellow or pre-silver) American Eels. During the first year of the study, 43 American Eels were tagged with the smaller tag (F1830, 4.5 month battery life), and the remaining individuals for that year $(n=29)$ and the final two years of the study $(n=73)$ were tagged with the larger tag (F1835, 18 month battery life) to ensure multi-year detections. Radio-tagged American Eels were $85.4 \mathrm{~cm} \pm 0.45 \mathrm{~cm}$ TL (mean $\pm \mathrm{SE}$, range $72.0-101.8 \mathrm{~cm}$ ) and weighed $1.39 \mathrm{~kg} \pm 0.025 \mathrm{~kg}$ (range 0.66-2.66 kg). All tagging occurred in the field immediately after capture and fish were released near the capture location within one to two hours after tagging.

Radio tracking of American Eel migration was conducted through a combination of stationary aerial and underwater receivers and mobile tracking. Stationary radio receivers (Advanced Telemetry Systems, R4500C) were deployed at the Millville, Warren, Luray and Shenandoah dams on the Shenandoah River as well as at the Little Falls Dam on the Potomac River and on the Dalecarlia Reservoir in the Washington Aqueduct system in 2007. Additional stationary receivers were added in 2008 to evaluate the Newport Dam (Figure 1). At the stationary locations, combinations of aerial and underwater antennas were used to determine 
the timing of passage at each monitoring location. Stationary radio receivers logged passage data continuously from September 2007, through August 2010. Mobile tracking was conducted periodically to determine locations of American Eels that did not progress to the next downstream dam (monitoring location) during the study period. Mobile tracking was conducted from roads that followed the South Fork and Shenandoah Rivers as well as along the Chesapeake \& Ohio (C\&O) Canal, which follows the northern shore of the Potomac River. Telemetry data were divided into three 1-year periods for analysis starting on 1 September and ending on 31 August of the following year.

Timing, Speed, and River Discharge Related to Migration Events

To determine the timing of migration relative to sunset and daylight, the time of passage at a monitoring location was compared to the sunset and sunrise times for the day of the migration event. Sunrise and sunset times were taken from TimeAndDate.com at the Leesburg, Virginia location (last accessed 12 October 2014). Time of passage was then converted to hours relative to the time of sunset on a given day. Passage during daylight hours was determined if the downstream passage event occurred after sunrise and before sunset.

The speed for migration was determined by dividing the distance traveled by the duration of migration. Duration for migration on the Shenandoah River was determined by the difference in departure time from the first and last dam passage events for an individual American Eel. The speed of migration was then calculated by dividing the time the individual American Eel used for downstream migration by the distance between the first and last detection points (range 21-195 km). For the Potomac River, the duration for migration was calculated by subtracting the departure time from the Millville Dam on the Shenandoah River 
from the departure time at the Little Falls Dam or Dalecarlia Reservoir. Migration speed on the Potomac River was calculated by dividing the duration of migration by the $99 \mathrm{~km}$ distance from the Millville Dam to either the Little Falls Dam or the Dalecarlia Reservoir.

Environmental Variable Data

Mean daily river discharge data were acquired from the U.S. Geological Survey Water Watch website (http://water.usgs.gov/waterwatch, last accessed 1 November 2014). Discharge data from the gauging station located at Luray Dam on the South Fork of the Shenandoah River were used to compare cumulative American Eel passage events by study year related to river discharge.

Results:

Radio detection probability at the stationary receivers was high for the Shenandoah River portion of the study area. Radio-tagged American Eels were detected at each Shenandoah River dam they passed during the study, with no individuals passing a dam without having at least one detection on a stationary receiver. Radio detection in the Dalecarlia Reservoir did not provide complete coverage as one tagged American Eel was detected via mobile tracking in the Reservoir after having passed the receiver location without being detected. No mobile tracking was conducted downstream of the tailrace of Little Falls dam to assess if any tagged American Eels passed that location without being detected.

\section{Downstream Migrations}

During the study, 96 of the 145 radio-tagged American Eels migrated downstream and passed at least one dam for a total of 319 dam passage (migration) events. Thirty-five American 
Eels passed dams during the first study year, 31 in the second year and 30 in the third year.

Eighty-one of the 96 American Eels were silver phase when tagged and 78 of those individuals migrated downstream during the same study year as tagging. The remaining three silver phase American Eels initiated downstream migrations during the fall about one year after being tagged. Eight American Eels (seven pre-silver and one yellow phase) migrated downstream in the same study year as being tagged. In addition, two pre-silver and five yellow phase individuals made downstream migrations about one year after being tagged, and the maturity stages of these individuals were unknown at the time of their migrations.

\section{Seasonal Timing of Migrations}

American Eels passed dams in every month of the year except July. Peak migration time differed for each of the three study years (1 September-31 August) (Figure 2). In 2007/2008, the highest number of dam passage events occurred in February and March, with 22\% occurring from September to December. In 2008/2009, October and December had the highest number of dam passage events, with $70 \%$ occurring from September to December. During 2009/2010, nearly all dam passage events occurred in November, with $97 \%$ of occurring from September to December. For all years combined, peak migration was in November and December (55\%). A total of $67 \%$ of migration events occurred during the previously documented (Euston et al., 1998) downstream migration period of September to December. Over $90 \%$ of all migration events occurred between 1 October and 1 May. Most American Eels completed downstream migrations in the same study year as when they had first passed a dam, with only two individuals that began downstream migrations in the spring and continued the following fall. The frequency of dam passage events by month was similar between successful 
(fish that passed a Potomac River monitoring location) and non-successful (fish that did not suffer immediate turbine mortality and were not detected at a Potomac River monitoring location) migrants (Figure 3).

The seasonal timing for either initial or final dam passage events for American Eels in the Potomac River basin was variable. Half of the initial dam passage events for an individual American Eel in the Shenandoah River occurred in November and December (27\% and 23\% respectively). An additional $16 \%$ of initial dam passage events occurred in February and $11 \%$ in October. Final passage events at the Potomac River stations (Little Falls Dam or Dalecarlia Reservoir) occurred primarily in December (46\%), but also occurred frequently in November (23\%), April (15\%) and March (8\%).

The timeframe to complete downstream migration out of the upper Potomac River appeared to be related to the timing of first dam passage. For those American Eels whose first dam passage event occurred on the Shenandoah River from September through November, those that successfully passed the Little Falls Dam or Dalecarlia Reservoir did so by no later than mid-December of the same year $(n=18)$. Two American Eels passed their first dam on the Shenandoah River in mid-December but did not migrate past Little Falls Dam until March and April of the following spring. Six American Eels passed their first dam on the Shenandoah River between February and April and five of those continued downstream to pass the Little Falls Dam or into the Dalecarlia Reservoir by mid-May of the same year. Only one American Eel in the study initiated downstream migration in the spring in the Shenandoah River and completed the migration past the Little Falls Dam the following winter of that year. That American Eel passed the first dam (Newport Dam) in late April 2009, then passed the Luray Dam in mid- 
October, the Warren and Millville dams in mid-November and then was later detected in the Dalecarlia Reservoir in early December 2009.

The timing of initial and final dam passage events for the remaining American Eels that were not detected at Potomac River Stations followed a similar pattern to those American Eels with successful migrations. Thirty-five American Eels passed at least two dams in the study and did not suffer turbine mortality. Of those 35 individuals, 19 (54\%) initiated migration from August through November and passed their last dam on the Shenandoah River by midDecember of the same year. An additional 11 American Eels (31\%) started their Shenandoah migration in December or January. Of those winter migrants, three ended their migration in the same month in which it was started and the remaining eight passed the Millville Dam in February through April of the following spring. The final five American Eels passed their first dam on the Shenandoah River between February and April and all passed their last dam (Warren or Millville) no later than May of the same year. None of the American Eels which were only detected in the Shenandoah River were documented to initiate migration in spring and continue the following fall.

The timing of the initial large pulse of downstream migrants appeared to be associated with magnitude of river discharge during the fall months (Figure 4). During the fall and winter months of the first study year, river discharge levels were relatively low in the Shenandoah River and less than $25 \%$ of passage events occurred before February 1, 2008. In early February, $25 \%$ of migration events occurred within 5 days during the same time as the highest river discharge event $\left(56 \mathrm{~m}^{3} \mathrm{~s}^{-1}\right)$ to date for that study year. There also were no large discharge events (i.e. greater than twice the median discharge) in the late fall or winter of that study year. 
In the second study year, $25 \%$ of passage events occurred by late October which did not appear to be related with peaks in discharge. However, a high discharge event $\left(82 \mathrm{~m}^{3} \mathrm{~s}^{-1}\right)$ occurred in mid-December of the same year in which $35 \%$ of passage events occurred during eight days. During the third study year, a high discharge event $\left(122 \mathrm{~m}^{3} \mathrm{~s}^{-1}\right)$ occurred in mid-November and $75 \%$ of passage events for that study year occurred in five days. Spring migration did not occur during the third study year.

\section{Daily Timing of Migration}

Migration past dams occurred during every hour of the day, but most migrations occurred during the night (Figure 5). A total of 35\% of dam passage events occurred within in first three hours after sunset. Relatively few (10\%) dam passage events occurred during daylight hours.

Migration Speed

The speed and duration of migration were variable for individual American Eels, but similar between the Shenandoah River and Potomac River portions of the study. Migration duration when passing at least two dams $(n=78)$ ranged from less than one day to $226 \mathrm{~d}$. The mean migration speed from first to last dam passage in the Shenandoah River was $22 \mathrm{kmd}^{-1}$ (SE = 3.8). Seventeen American Eels passed all five dams on the Shenandoah River for a distance of $195 \mathrm{~km}$. The mean time to complete the entire migration was $38 \mathrm{~d}$ (SE $=12$, range 1 to 188 ) at a mean rate of $29 \mathrm{kmd}^{-1}$ (SE = 12). The fastest movement recorded was for an individual that passed all five dams $(195 \mathrm{~km})$ in $28 \mathrm{~h}\left(165 \mathrm{kmd}^{-1}\right)$. The slowest movement was an American Eel that traveled the same distance in $188 \mathrm{~d}\left(1.0 \mathrm{kmd}^{-1}\right)$. Mean migration speed was $26 \mathrm{kmd}^{-1}(\mathrm{SE}=$ 6.6) for American Eels leaving the Millville Dam and being detected at a Potomac River Station 
$(n=26)$ at a distance of $99 \mathrm{~km}$. The mean duration for passage from Millville Dam to passage at Little Falls Dam or detection in Dalecarlia Reservoir was $11 \mathrm{~d}$ (SE = 1.5, range 1 to 24).

\section{Discussion:}

This is the first study to document American Eel downstream migrations occurring outside the range of a well-defined latitude-based migration period, including evidence of spring migration. Downstream migration of silver American Eels in the spring appeared to be a typical migration pattern in the Potomac River, particularly in years without high discharge events during the fall months. Spring dam passage events occurred in two of the three study years, with peak passage for the first study year during the spring. In a previous study on silver American Eels in the Shenandoah River, Euston et al. (1998) documented fall migration to occur based on sampling at the Luray Dam. However, Euston et al. (1998) did not monitor for downstream migrants during winter, spring, or summer, so it was possible that American Eels may have been migrating throughout the remainder of the year and not documented. Of the three study years that were monitored, a relatively complete fall-only migration occurred during the fall of 2009, when nearly all the tagged American Eels completed migration within the Potomac River basin within a few days in November. The previous two study years that were monitored did have American Eels migrations during the fall, but also had downstream migrations in late winter and spring as well.

There have been several studies on the European Eel $A$. anguilla that have documented spring migrations like those observed in the Potomac River basin. The European Eel, which also spawn in the Sargasso Sea and has a similar life history strategy to the American Eel, with a 
similar fall peak migration period. Late winter and spring migrations have been documented in two European rivers (Feunteun et al., 2000; Aarestrup et al., 2008; Acou et al., 2008; McCarthy et al., 2008; Reckordt et al., 2013). In those studies, it was suggested that dams were the potential cause of delayed migrations from the typical fall season and the studies also suggested that step-wise multi-year downstream migration pattern may be a typical strategy for European Eel.

Although there are multiple dams on the Shenandoah and Potomac Rivers, it is unlikely that delays caused by dams are the explanation for the occurrence of spring migration. In the majority of migrations, American Eels moved relatively quickly downstream, completing migrations out of the Shenandoah and the upper Potomac River within one to two months of initiating migration. Those American Eels that initiated and completed migrations in the fall did so in approximately the same amount of time as those American Eels that initiated and completed migrations in the spring. Only American Eels that initiated migrations in late December may have been delayed slightly, resuming migrations in the spring months, but that may be due to water temperatures being below preferred migration temperatures for American Eels in the Shenandoah River (this study, unpublished data). In addition, the mean speed of migration past all five dams on the Shenandoah River was similar to the mean migration speed through the upper Potomac River, where no dams are present to impede migration. Finally, outmigrating American Eels were typically in the vicinity of a dam for less than one day (this study, unpublished data), so it is unlikely that delays caused by the five dams on the Shenandoah River would result in overall delays in downstream migration of several months. 
Another potential explanation for spring migrations of silver American Eels in the Potomac River basin may be that they are making partial annual movements toward the Sargasso Sea and waiting in a more downstream location for optimal migratory conditions the following year (Aarestrup et al., 2008; Reckordt et al., 2013). Only two of the 96 migrating American Eels in the study initiated downstream migration in the spring and resumed migration the following fall. The first American Eel started migrations in late April and passed three dams on the Shenandoah River before stopping migration. Downstream movements were resumed in October of the same year with two dam passage events occurring prior to turbine mortality at the Millville Dam. The second American Eel demonstrating partial downstream migrations passed one dam in April and then passed the remaining three dams in the Shenandoah River and the Little Falls Dam of the Potomac River in October through December of the same year. Since only two of the 96 migrating American Eels in the study demonstrated a multi-year migration pattern, it is unlikely that spring migrations are a result of partial migrations, at least through the upper Potomac River basin.

About one-third of the American Eels in the study did not complete migrations during the lifespan of the radio tag, and the passage events that were recorded may have been the result of a deliberate partial downstream migration pattern. For the American Eels that did not complete migration, the proportion of initial passage dates during spring and fall were similar to those American Eels that completed their migration. It is possible that these American Eels may have temporarily ceased migrations and waited for a more optimal time to complete their migration to the Sargasso Sea. However, particularly in the case of the American Eels with the 18-month radio tag battery, multi-year downstream migration was rarely documented and it is 
more plausible that those American Eels shed their radio tags, the radio tag batteries failed, or the individuals suffered latent mortality as several of them had passed through turbines during their last known dam passage event.

With spring migrating American Eels, it is unclear how the timing of migration may impact future spawning success unless they are delaying migrations in the lower Potomac River or Chesapeake Bay until the following fall. Assuming that the spring migrating American Eels continue out of the Potomac River and Chesapeake Bay to the Sargasso Sea, silver American Eels would presumably arrive to the spawning grounds during late summer and fall. Although no adult American Eels have been observed on the spawning grounds, leptocephali collections suggest that spawning occurs between February and April (McCleave et al., 1987), with peak spawning thought to occur in February (Kleckner and McCleave, 1985). Based on leptocephali collections and the seasonal arrival of glass eels to the Atlantic Coast (Jessop, 1998; Wang and Tzeng, 2000; Powles and Warlen, 2002; Wuenschel and Able, 2008; Dutil et al., 2009), it is unlikely that American Eels spawn year-round. Because an extended spawning period is unlikely for late-arriving fish, it is unclear if American Eels that initiate spawning migrations in the spring would contribute to the spawning population.

Until a better understanding is gained for the spawning success of these spring migrants from the Potomac River, it is prudent to consider options for the protection of American Eels regardless of the timing of downstream migration. Currently, a seasonal nighttime turbine shutdown period (15 September-15 December, 18:00-06:00 h) is implemented at the five Shenandoah River hydroelectric dams to protect downstream migrants. To protect the spring migrating American Eels in the Shenandoah River, the seasonal shutdown period could be 
extended to include late December and spring months (i.e., February through April). In addition, studies could be conducted at the Washington Aqueduct water intake to gain better resolution on the entrainment rate of silver American Eels into the municipal water supply. Understanding that downstream migration of American Eels is not necessarily limited to a short seasonal time period in the Potomac River watershed, management and protective measures for downstream migrants should not be limited to fall months. 


\section{References:}

Aarestrup, K., Thorstad, E. B., Koed, A., Jepsen, N., Svendesen, J. C., Pedersen, M. I., Skov, C., and $\varnothing$ kland, F. 2008. Survival and behavior of European silver eel in late freshwater and early marine phase during spring migration. Fisheries Management and Ecology, 15: 435-440.

Acou, A., Laffaille, P., Legault, A., and Feunteun, E. 2008. Migration pattern of silver eel (Anguilla anguilla, L.) in an obstructed river system. Ecology of Freshwater Fish, 17: 432442.

Brown, L., Haro, A. and Castro-Santos, T. 2009. Three-dimensional movement of silver-phase American eels in the forebay of a small hydroelectric facility. In Eels at the Edge: Science, Status, and Conservation Concerns, pp. 271-291. Ed. by J. M. Casselman and D. K. Cairns. American Fisheries Society, Symposium 58, Bethesda, Maryland.

Côté, C. L., Gagnaire, P. -A., Bourret, V., Verreault, G., Castonguay, M., and Bernatchez, L. 2013. Population genetics of the American eel (Anguilla rostrata): $F_{s t}=0$ and North Atlantic oscillation effects on demographic fluctuation of a panmictic species. Molecular Ecology, 22: 1763-1776.

Dutil, J. -D., Besner, M., and McCormick, S. D. 1987. Osmoregulatory and ionoregulatory changes and associated mortalities during the transition of maturing American eels to a marine environment. In Common Strategies of Anadromous and Catadromous Fishes, pp. 175-190. Ed. M. J. Dadswell, R. J. Klauda, C. M. Moffitt, and R. L. Saunders. American Fisheries Society, Symposium 1, Bethesda, Maryland. 
Dutil, J. -D., Dumont, P., Cairns, D. K., Galbraith, P. S., Verreault, G., Castonguay, M., and Proulx, S. 2009. Anguilla rostrata glass eel migration and recruitment in the estuary and Gulf of St. Lawrence. Journal of Fish Biology, 74: 1970-1984.

Euston, E. T., Royer, D. E., and Simons, C. L. 1998. American eels and hydro plants: clues to eel passage. Hydro Review (August), 17: 94-103.

Facey, D. E., and Helfman, G. S. 1985. Reproductive migrations of American eels in Georgia. Proceedings of the Annual Conference of the Southeastern Association of Fish and Wildlife Agencies, 39: 132-138.

Feunteun, E., Acou, A., Laffaille, P., and Legault, A. 2000. European eel (Anguilla anguilla): prediction of spawner escapement from continental population parameters. Canadian Journal of Fisheries and Aquatic Sciences, 57: 1627-1635.

Haro, A., Castro-Santos, T., Whalen, K., Wippelhauser, G., and McLaughlin, L. 2003. Simulated effects of hydroelectric project regulation on mortality of American eels. In Biology, Management, and Protection of Catadromous Eels, pp. 357-365. Ed. D. A. Dixon. American Fisheries Society, Symposium 33, Bethesda, Maryland.

Harrell, R. M., and Loyacano, H. A. 1982. Age, growth and sex ratio of the American eel in the Cooper River, South Carolina. Proceedings of the Annual Conference of the Southeastern Association of Fish and Wildlife Agencies, 34: 349-359.

Ingraham, D. L. 1999. Sex ratios and maturation patterns of the American eel, Anguilla rostrata (Le Sueur), in four locations of the Saint John River system, New Brunswick. Master's thesis. University of New Brunswick, New Brunswick. 
Jessop, B. M. 1998. Geographic and seasonal variation in biological characteristics of American eel elvers in the Bay of Fundy area and on the Atlantic coast of Nova Scotia. Canadian Journal of Zoology, 76: 2172-2185.

Jessop, B. M. 2010. Geographic effects on American eel (Anguilla rostrata) life history characteristics and strategies. Canadian Journal of Fisheries and Aquatic Sciences, 67: $326-346$.

Kleckner, R. C., and McCleave, J. D. 1985. Spatial and temporal distribution of American eel larvae in relation to North Atlantic Ocean current systems. Dana, 4: 67-92.

McCarthy, T. K., Frankiewicz, P., Cullen, P., Blaszkowski, M., O’Connor, W., and Doherty, D. 2008. Long-term effects of hydropower installations and associated river regulation on River Shannon eel populations: mitigation and management. Hydrobiologia, 609: 109124.

McCleave, J. D., Kleckner, R. C., and Castonguay, M. 1987. Reproductive sympatry of American and European Eel and implications for migration and taxonomy. In Common Strategies of Anadromous and Catadromous Fishes, pp. 286-297. Ed. M. J. Dadswell, R. J. Klauda, C. M. Moffitt, and R. L. Saunders. American Fisheries Society, Symposium 1, Bethesda, Maryland.

McGrath, K. J., Bernier, J., Ault, S., Dutil, J. -D., and Reid, K. 2003. Differentiating downstream migrating American eels Anguilla rostrata from resident eels in the St. Lawrence River. In Biology, Management, and Protection of Catadromous Eels, pp. 315-327. Ed. D. A. Dixon. American Fisheries Society, Symposium 33, Bethesda, Maryland. 
Powles, P. M., and Warlen, S. M. 2002. Recruitment season, size, and age of young American eels (Anguilla rostrata) entering an estuary near Beaufort, North Carolina. Fishery Bulletin, 100: 299-306.

Reckordt, M., Ubl, C., Wagner, C., Frankowski, J., and Dorow, M. 2013. Downstream migration dynamics of female and male silver eels (Anguilla anguilla L.) in the regulated German lowland Warnow River. Ecology of Freshwater Fish, 23: 7-20.

Wang, C. H., and Tzeng, W. N. 2000. The timing and metamorphosis and growth rates of American and European Eel leptocephali: a mechanism of larval segregative migration. Fisheries Research, 46: 191-205.

Welsh, S. A., and Liller, H. L. 2013. Environmental correlates of upstream migration of yellowphase American Eels in the Potomac River Drainage. Transactions of the American Fisheries Society, 142: 483-491.

Wuenschel, M. J., and Able, K. W. 2008. Swimming ability of eels (Anguilla rostrata, Conger oceanicus) at estuarine ingress: contrasting patterns of cross-shelf transport? Marine Biology, 154: 775-786. 
Figure 1. Shenandoah and Potomac river watersheds and location of five hydroelectric dams and a water supply dam and reservoir monitored with stationary radio telemetry for silver American Eel passage. All silver American Eel collection and tagging occurred in the Shenandoah River watershed upstream of the Luray Dam.

Figure 2. Percent of American Eel dam passage events by month during the three study years on the five hydroelectric dams on the Shenandoah River, and the Little Falls Dam and Dalecarlia Reservoir on the Potomac River. Eel passage was monitored continuously from September 2007-August 2010. Annual study periods began on 1 September and continued through 31 August of the following year.

Figure 3. Percent of American Eel dam passage events by month for successful (fish migrating past a Potomac River monitoring station) and non-successful (fish not detected at a Potomac River monitoring station) migrants in the Potomac River basin.

Figure 4. Daily average river discharge values compared to cumulative American Eel dam passage events by study year (1 September to 31 August, 2007-2010) in the Potomac River basin.

Figure 5. Percent of American Eel dam passage events by hour relative to sunset at five hydroelectric dams on the Shenandoah River, and the Little Falls Dam and Dalecarlia Reservoir on the Potomac River from 2007-2010. Sunset occurred between hours -1 and 0. 


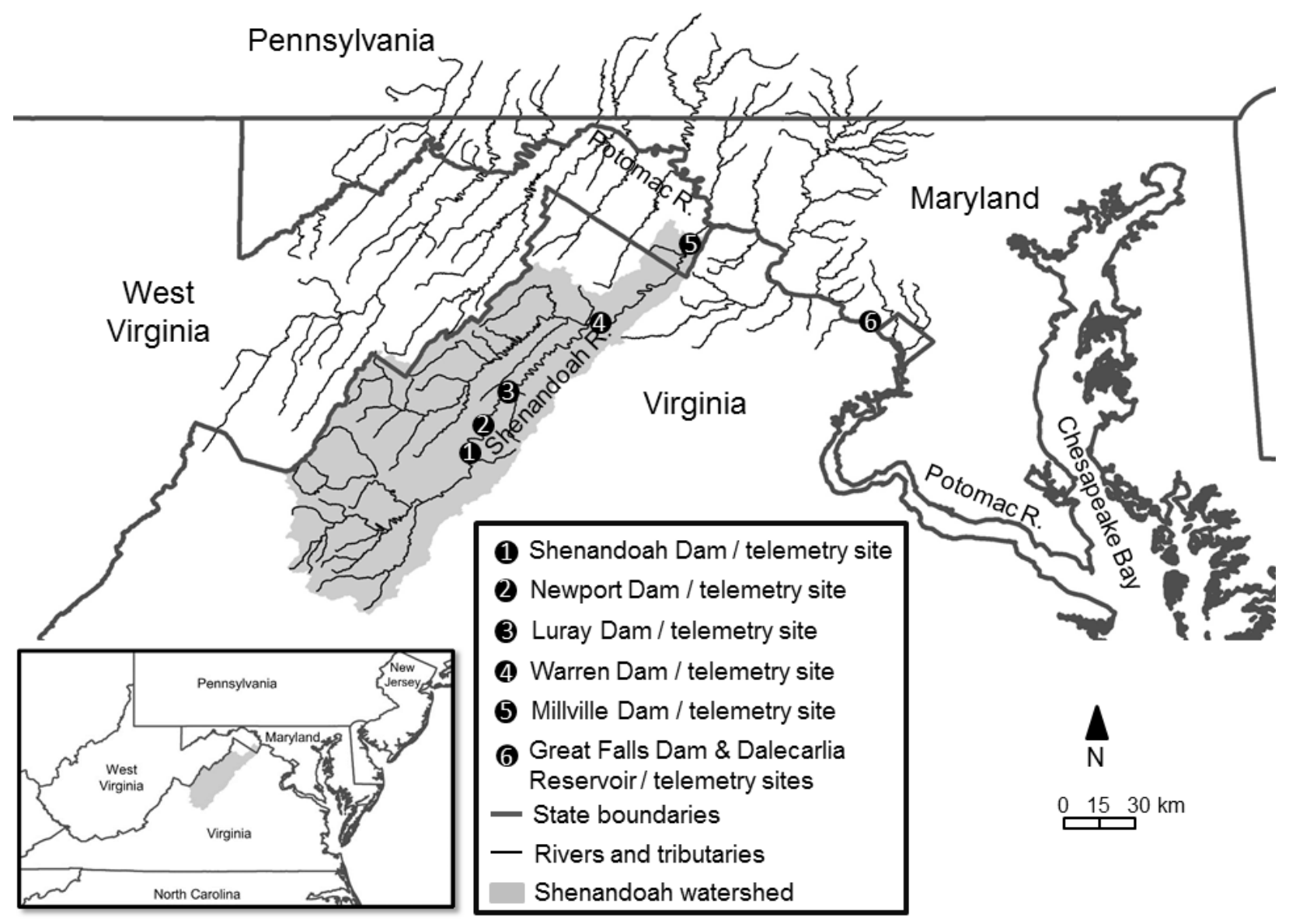




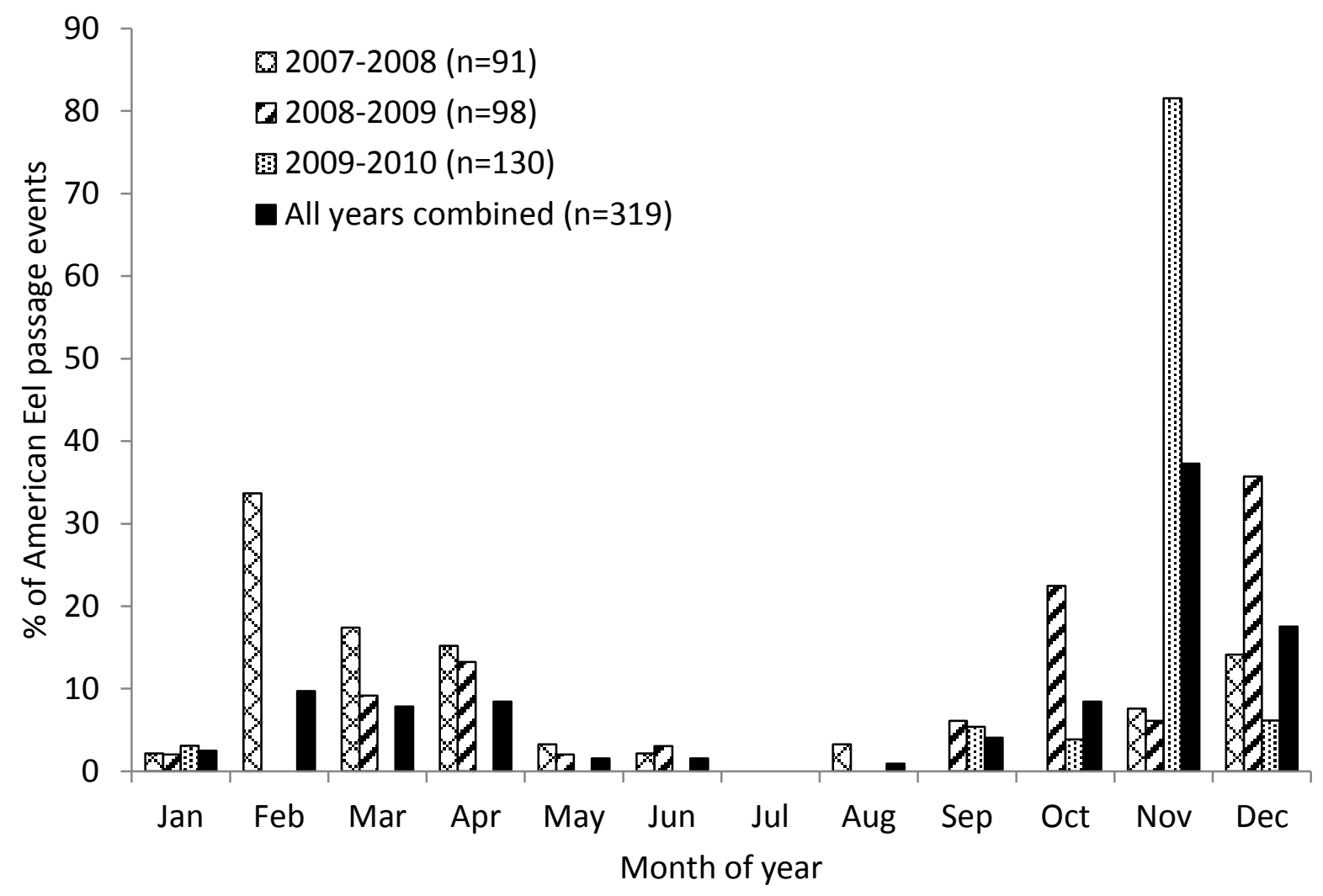




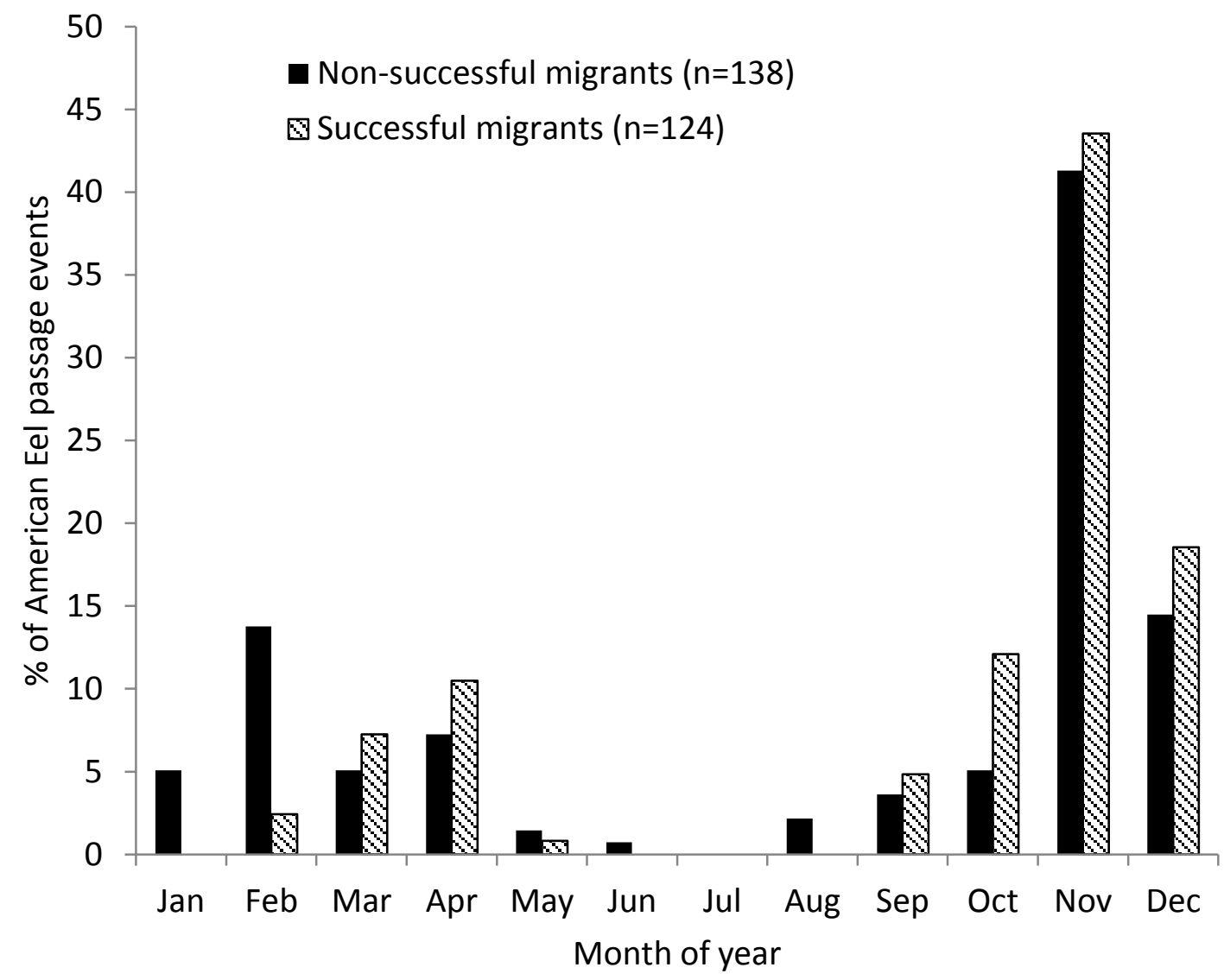



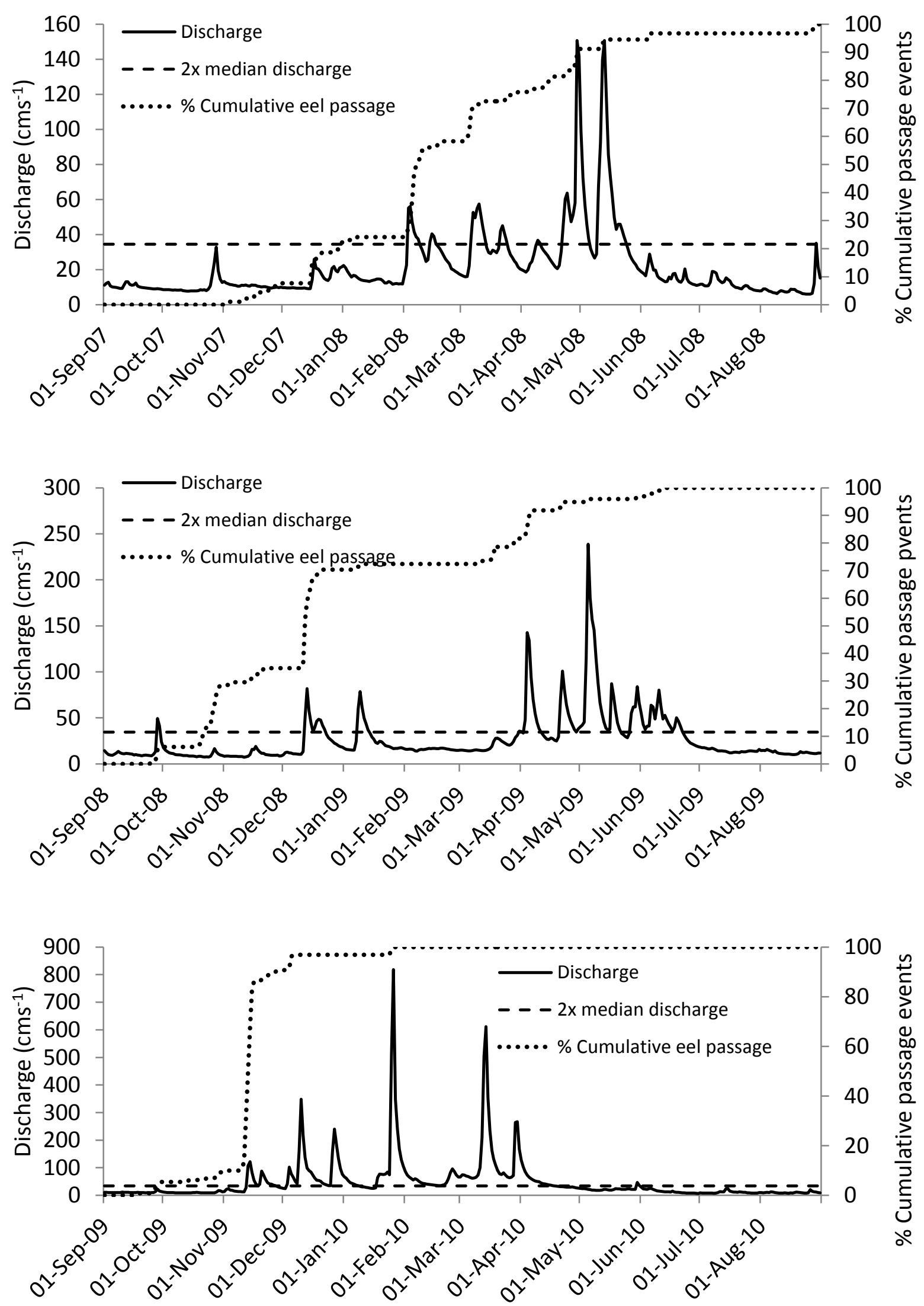


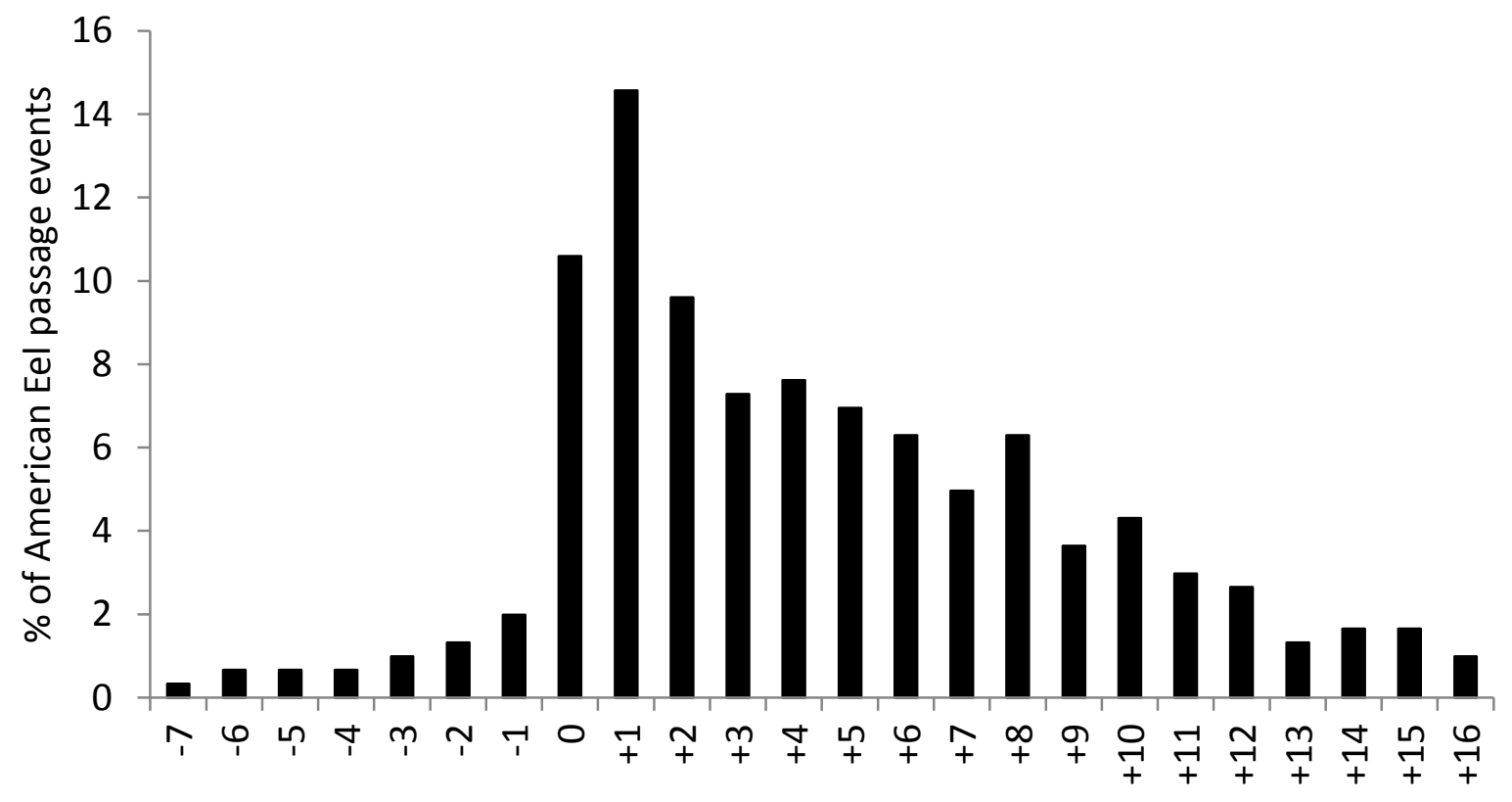

Hour of passage relative to sunset 
Chapter 3 - Environmental variables associated with American Eel (Anguilla rostrata) downstream migrations in the Shenandoah River

Abstract:

The timing of downstream migrations of silver American Eel (Anguilla rostrata) have been associated with environmental variables. To determine if environmental variables were associated with dam passage events on the Shenandoah River, a total of 96 American Eels were radio-tagged and monitored while migrating downstream past five hydroelectric dams. Over the three-year study, 292 dam passage events were recorded. A logistic regression model was developed to determine which environmental variables were associated with dam passage events. The model was able to properly assign $85 \%$ of passage and non-passage days during the study. The model also determined that passage was more likely to occur during high river discharge and when the proportion of current day's discharge was higher than the previous 5day average of discharge (i.e. increase in discharge). Passage occurred most frequently when water temperatures were between 5 and $12^{\circ} \mathrm{C}$. Similar to other rivers where out-migration of American Eel has been studied, river discharge and water temperature were the environmental variables most closely associated with downstream migration events of American Eels in the Shenandoah River.

Introduction:

Downstream migrations of silver American Eel (Anguilla rostrata) are typically characterized by peaks in movement interspersed with periods of no movement during the 
migration season. Predicting the timing of downstream American Eel migrations has been problematic because of these sporadic migratory events. Understanding the timing of downstream migrations could refine the timing of implementing protection measures for downstream migrants, particularly for rivers with hydroelectric dams and their potential for turbine-related mortality. Several studies have focused on determining what factors may regulate downstream migration events, and which changing environmental variables likely play a role in triggering migration events for silver American Eels (Behrmann-Godel and Eckmann, 2003; Haro et al., 2003; Trancart et al., 2013).

Understanding the timing and environmental cues associated with downstream migration events can be an important component of efforts to protect downstream migrating American Eels at hydroelectric dams and other migration barriers. At some dams, operational or other protection measures are only implemented during the downstream migration season (e.g. Becker et al., 2009). Implementation of protective measures can be set to calendar dates (Haro et al., 2003); however migration may not occur during a large portion of those days (Travade et al., 2010; Trancart et al., 2013). If implementation of protective measures during the migration season could be linked to environmental variables, then the number of days the protective measures would have to be implemented could be reduced, without altering the overall protection for downstream migrating American Eels.

Based on studies of the American and European Eel (A. anguilla), the primary environmental variables that appear to be most closely linked with peaks in eel migration are water temperature, river discharge, and lunar phase. Downstream migration occurs over a wide range of temperatures, but peak migrations typically occur between 5-9 ${ }^{\circ} \mathrm{C}$ (Euston et al., 1998; 
Acou et al., 2008). Within the optimal temperature range, an increase in discharge is likely an additional cue for downstream migrations (Behrmann-Godel and Eckmann, 2003; Cullen and McCarthy, 2003; Durif et al., 2003; Wantene et al., 2003; Acou et al., 2008; Bruijs et al., 2009; Travade et al., 2010). Some studies also indicate that American Eels migrate during darker phases of the moon (Winn et al., 1975; Euston et al., 1998).

To determine if environmental variables were associated with downstream migrations of the American Eel, a study was conducted relative to five hydroelectric dams on the Shenandoah River in Virginia and West Virginia. Allegheny Energy Supply (currently PE Hydro Generation, LLC), owner of all five hydroelectric dams, had manipulated hydroelectric generation through seasonal nighttime turbine shutdowns as a method to decrease turbine mortality during the assumed peak silver American Eel migration period. I attempted to determine if environmental variables could be used to further refine the days in which turbine shutdowns could be implemented to protect migrating American Eels at hydroelectric dams within the Shenandoah River watershed.

Methods:

Site Description

The Shenandoah River, the largest tributary of the Potomac River, has a watershed area of $7,870 \mathrm{~km}^{2}$. The river flows north from its headwaters in central Virginia to its confluence with the Potomac River near Harpers Ferry, West Virginia. There are five hydroelectric dams on the Shenandoah River (Figure 1). The Shenandoah, Newport, and Luray dams are located on the South Fork of the Shenandoah River in Virginia. The remaining two dams, Warren and Millville 
dams, are located on the mainstem Shenandoah River in Virginia and West Virginia, respectively.

All hydroelectric dams on the Shenandoah River are run-of-the-river and must maintain a $2.5 \mathrm{~cm}$ minimum spill over the dam. The dams range in height from 4.5-8.7 $\mathrm{m}$ and rated project capacity ranges from 0.75-2.83 MW. Ladders for upstream American Eel passage have been recently installed on the three lowermost dams and American Eels are present in the watershed above all five dams. American Eels moving downstream at all five dams are expected to either spill over the top of the dam or travel through the turbines. The hydroelectric company currently conducts turbine shutdowns from September 15 through December 15 between 18:00 and 06:00 hours to protect downstream migrating silver American Eels. Field Methods

American Eels were collected between September and December in 2007, 2008 and 2009 by electrofishing at various locations in the Shenandoah River, with all collection locations upstream of the Luray Dam. A total of 145 American Eels were radio-tagged, including 92 silver phase, 25 large yellow phase, and 28 pre-silver phase individuals (an intermediate maturity stage between yellow and silver). Radio-tagged American Eels were $85.4 \mathrm{~cm} \pm 0.45 \mathrm{~cm}$ TL (mean $\pm \mathrm{SE}$, range $72.0-101.8 \mathrm{~cm}$ ) and weighed $1.39 \mathrm{~kg} \pm 0.025 \mathrm{~kg}$ (mean $\pm \mathrm{SE}$, range 0.66-2.66 kg). All American Eels were tagged with coded radio tags (F1835 or F1830, Advanced Telemetry Systems, Inc., MN). Tags were surgically implanted in the field at the collection location and all radio-tagged American Eels were released within one to two hours of capture at the collection site. 
Radio-telemetry monitoring receivers were installed at all hydroelectric dams and were operated continuously from September 2007 through July 2010. A total of 18 radio receivers (Advanced Telemetry Systems, R4500C) were deployed between the five hydroelectric dams on the Shenandoah River to determine time of American Eel passage at each facility.

\section{Environmental Variable Data}

Mean daily river discharge data were acquired from the U.S. Geological Survey's Water Watch website (http://water.usgs.gov/waterwatch). Discharge data from the gauging stations located on the South Fork and the mainstem of the Shenandoah River were used for data analyses. River discharge data were used from the Lynwood station (for Shenandoah Dam), the Luray station (for Luray and Newport dams), the Front Royal station (for Warren Dam), and the Millville station (for Millville Dam). Mean daily water temperature data for the river were acquired from the Luray gauging station. Lunar phase data were acquired from the U.S. Naval Observatory (http://www.usno.navy.mil/USNO/astronomical-applications).

\section{Data Analysis}

Telemetry data were evaluated for each individual fish at each dam. The date and location of each passage event for tagged American Eels were used for analysis. Passage event data were divided into three one-year periods for analysis starting on date August 1 and ending on July 31 of the following year. Environmental data were evaluated beginning at the date of tagging or starting on August 1 of the year when migration was initiated, whichever occurred later. The last date of passage for an American Eel at a dam was used as an ending date for environmental variables to be considered in the analysis for that fish. American Eels that had migration events over two one-year periods had all environmental data included for both years. 
Several manipulations of environmental variables were considered in developing the best fitting model to describe when downstream passage events occurred in the study (Table 1). For river discharge, both actual values of discharge (D) and natural $\log \left(\log _{e}\right)$ transformed (LD) values for discharge were evaluated. To determine if changes in discharge were associated with migration events, I calculated the proportion of the current day's discharge against the average discharge from the previous two days (DP2) or five days discharge (DP5). Discharge proportion data were also natural $\log \left(\log _{e}\right)$ transformed (LDP2 and LDP5). Water temperature data were evaluated for both actual values (TEMP) and values divided into five bins (TEMPB). Temperature bins were developed based on downstream passage data in the Shenandoah River from Euston et al. (1998). Bins $1\left(<6.0^{\circ} \mathrm{C}\right)$ and $5\left(>22.0^{\circ} \mathrm{C}\right)$ encompassed temperatures where passage had not been previously documented. Bin 3 included the range of peak passage temperatures $\left(9.0-13.9^{\circ} \mathrm{C}\right)$. Bins $2\left(6.0-8.9^{\circ} \mathrm{C}\right)$ and $4\left(14.0-22.0^{\circ} \mathrm{C}\right)$ included temperatures where some downstream migration had occurred in the Euston et al. (1998) study. The percent of lunar illumination (LUN) was used in model development, with $0 \%$ representing new moon conditions and $100 \%$ representing full moon conditions.

Additional variables not associated with environmental cues were also included in the analysis. Date was evaluated using the variables of season, modified Julian date, and study year. Season (SEA) was divided into the categories of spring (Mar-May), summer (Jun-Aug), fall (Sep-Nov), and winter (Dec-Feb). Modified Julian date (MD) was the sequential day in the year starting with day 1 on August 1. Study year (YR) was also used in model development with year beginning on August 1 of 2007, 2008, and 2009. Location (LOC) was also evaluated to determine if the individual dams had a significant influence on migration. 
A logistic regression model (Hosmer and Lemeshow, 2000) with repeated measures (glmer, R Package version 2.15.1) was used to evaluate the relationship between environmental, date, and location variables and American Eel downstream migrations past dams. The logistic regression with repeated measures was able to account for variability that may be associated with multiple passage events by individual American Eels in the study as well as evaluate environmental variable data that were not normally distributed. For data analysis, I assigned a binomial response ( $1=$ pass, $0=$ no pass) for each American Eel $(Y)$ for each day it was present in the study. I then used logistic regression to determine the passage probability based on input parameters from measured environmental, date and location variables,

$$
E\left(Y_{i j}\right)=\frac{\exp \left(\beta_{0 j}+\beta_{1 j} x_{i j}+\ldots+\beta_{p} x_{i j}+R_{i j}\right)}{1+\exp \left(\beta_{0 j}+\beta_{1 j} x_{i j}+\ldots+\beta_{p} x_{i j}+R_{i j}\right)}
$$

where $E(Y)$ is the expected probability of passage as a function of measured variables $(x)$ and the random error term $(\mathrm{R})$.

Information criterion scores, based on parsimony and fit, were used to select the best model to describe passage events. The Bayesian Information Criterion (BIC) was selected as the most appropriate information criterion to evaluate model fit. The BIC was selected, rather than Akiaike Information Criterion (AIC), because BIC reduces likelihood of overfitting that can occur when using AIC with large datasets (Aho et al., 2014). The BIC also favors the "true" model for the data, where AIC is better suited for predictive accuracy. The model with the lowest BIC score was determined to be the best fitting model.

Model development began with determining which configuration of discharge, proportion of discharge, and water temperature best described the data. Variable selection for 
proportion of discharge was determined by which single variable (DP2, DP5, LDP2 or LDP5) model resulted in the lowest BIC score. Using the best variable to describe proportion of discharge, two additional models were developed adding $D$ and $L D$ and then compared to determine which discharge value resulted in a better model fit. Using a model with the best variables for proportion of discharge and discharge, two additional models were created adding discrete (TEMP) and categorical water temperature (TEMPB) to select the better variable to describe water temperature. After the best variables were selected for discharge, proportion of discharge and water temperature, the resulting model was considered the base model for future model development. From that base model, the remaining variables (YR, LUN, SEA, MD, and LOC) were added one at a time and retained only if the model fit improved. Interaction terms were then added for combinations of LD, LDP5, LOC and YR to the model and retained if they improved model fit.

Once a model was developed using variables that resulted in the lowest BIC score, multicolinearity and model fit were assessed. Since using correlated variables can influence the interpretation of parameter estimates in the final model, a variance inflation factor (VIF) was calculated for the final model and colinearity would be significant if the VIF factor was greater than 10 (O'Brien, 2007). Pearson's Correlation Coefficient was also evaluated between significant variables in the final model to further explore relationships between parameters. Model fit was evaluated by developing a prediction matrix to describe correct and incorrect predictions for downstream passage. The cutpoint used in the prediction matrix to assign passage or no passage was determined by the value that optimized both sensitivity (true positive rate) and specificity (true negative rate) of the model (Greiner et al., 2000). 
Results:

A total of 96 radio-tagged American Eels moved downstream and passed at least one dam, including 34 in 2007-2008, 32 in 2008-2009, and 30 in 2009-2010. All but two of the radio-tagged fish completed downstream migrations within one migration season. A total of 292 dam passage events were recorded for radio-tagged American Eels, and migration past dams occurred on 109 different days during the three-year study. American Eels migrated downstream past dams in every month of the year except July. Peak migration time differed for each of the three study years (Figure 2).

Environmental Variables Associated with Migration

American Eels passed dams on the Shenandoah River at a wide range of river discharge levels. Downstream migration events past dams generally occurred during times of relatively high discharge, however passage was observed during nearly the entire range of discharge levels that occurred in the Shenandoah River during the study (Figure 2). Mean discharge during passage events was nearly twice as high as overall mean discharge at four of the five dams from August 2007 through July 2010 (Table 2). Most downstream passage events (63\%) occurred when discharge increased by at least $50 \%$ and over half (53\%) of the passage events occurred when discharge was at least doubled compared to the average discharge from the previous five days.

Water temperatures in the Shenandoah River ranged from $0^{\circ} \mathrm{C}$ to $29^{\circ} \mathrm{C}$. All downstream passage events at dams occurred between $3^{\circ} \mathrm{C}$ and $23^{\circ} \mathrm{C}$. Most passage events $(77 \%)$ occurred when temperatures were between $5^{\circ} \mathrm{C}$ and $12^{\circ} \mathrm{C}$ (Figure 3). Nearly all (87\%) of the passage events occurred after the river temperature dropped below $13^{\circ} \mathrm{C}$ in the fall and before 
temperatures warmed above $13^{\circ} \mathrm{C}$ in spring. Passage events in the spring were uncommon (8\%) after water temperatures reached $13^{\circ} \mathrm{C}$.

Silver American Eels migrated past dams during all lunar phases during this study. Over half (54\%) of migration events occurred when the moon was less than $25 \%$ illuminated.

However, $20 \%$ of downstream migrating American Eels passed dams during periods when the lunar illumination was greater than $75 \%$. American Eels also passed dams during periods of full moon (e.g. December 12, 2008), when the lunar event coincided with a period of increased discharge.

\section{Modeling Environmental Variables}

In developing the best fitting logistic regression model, the most appropriate variable to describe change in discharge was evaluated first. For change in discharge (proportion of previous discharge), the single variable model using LDP5 performed better than the other variables considered (Table 3). When discharge was added to the model with LDP5, the model with LD performed better than the model using $\mathrm{D}$ (Table 3). When temperature was added to a model with LD and LDP5, the TEMPB model performed better than the same model using TEMP (Table 3). Based on these results, the base model for future development included the LDP5, LD, and TEMPB variables to describe proportion of discharge, discharge, and water temperature.

When the remaining variables were added singly to the base model, none improved model fit (Table 3). The addition of the interaction terms between LDP5 and LD, LD and LOC, or LDP5 and YR also did not improve the performance of the base model (Table 3). The base model using LDP5, LD, and TEMPB was the subsequent best model ( $B I C=1625$, Table 4). 
Best Model:

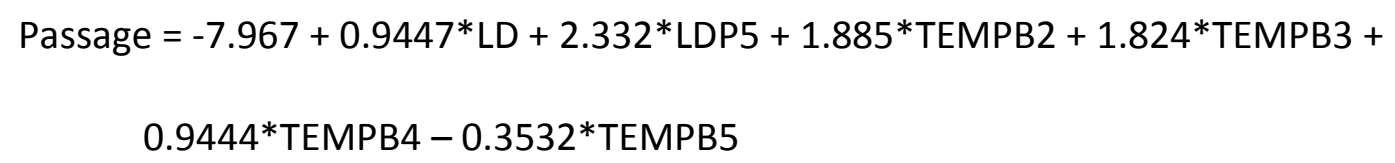

When evaluating colinearity of variables in the model, the VIF for the model was calculated to be 2.11 , indicating that multicolinearity is not a significant problem complicating model performance (O'Brien, 2007). Two of the variables included in the best model, LD and LDP5, were moderately correlated (Pearson's Correlation Coefficient $=0.44, p<0.001$ ), however, removal of either variable from the model did not substantially change the parameter estimate for the remaining variable. The standard errors for all parameter estimates were relatively small (less than 1), suggesting that the correlation between variables was not impacting model performance.

The model correctly assigned $85 \%$ of the passage and non-passage events, using a cutpoint of 0.030 to assign passage. The model assigned passage to occur on 253 days and no passage to occur on 768 days. Passage actually occurred on 109 days and did not occur on 815 days. Passage was assigned on more days in the first two years (102 and 105 days) of the study than the third year (46 days). The lower number of assigned migration days in the final study year was a result of most American Eels leaving the study area during the fall, with only one fish remaining to migrate in late January. Because all tagged fish had left the system by late January, any potential passage dates (based on environmental variables) in spring of the final study year were not included in analysis because no tagged American Eels were remaining in the river to monitor for migration. 
The parameter estimates in the model for temperature and discharge and change in discharge describe how the environmental variables were related to downstream American Eel passage events (Table 4). For every one unit increase in the LDP5 parameter, an American Eel was 10.3 times $(95 \% \mathrm{Cl} 6.9-15.3)$ more likely to pass downstream, regardless of other factors. For each one unit increase in LD, downstream passage was 2.6 times more likely to occur $(95 \% \mathrm{Cl}$ 2.0-3.3). Because the LDP5 parameter is the natural log of DP5, and the LD parameter is the natural log of $D$, the rate of increased likelihood of passage is reduced as values for discharge and proportion of discharge (DP5 and D) approach the higher values of the range. Passage was over 6 times more likely to occur when water temperatures were in the range of $6-13.9^{\circ} \mathrm{C}$ (TEMPB 2 and 3), than for when temperatures were below $6^{\circ} \mathrm{C}$ or above $22^{\circ} \mathrm{C}$ (TEMPB 1 and 5). Passage was 2.5 times more likely to occur if water temperature was in the range of $14-22^{\circ} \mathrm{C}$ (TEMPB 4) than compared to temperatures below $6^{\circ} \mathrm{C}$ (TEMPB 1). The model supported the field observations that American Eels migrated downstream during high discharge events and when water temperatures were within an intermediate range.

\section{Discussion:}

Silver American Eel migrations in the Shenandoah River generally followed previously documented studies indicating environmental variables were related to downstream migration events. Increasing river discharge, sometimes reported as rainfall events, is frequently cited as a factor associated with silver American and European Eel migrations (Smith and Saunders 1955; Winn et al., 1975; Haro et al., 2003; Behermann-Godel and Eckmann, 2003; Durif et al., 2003; Durif and Elie, 2008; Verbiest et al., 2012). In the Shenandoah River, increases in river discharge 
by $50 \%$ or more was an important variable associated with downstream migration events past dams. Those results are consistent with a study on European Eels indicating that increases in discharge (200-300\% or more) were associated with larger numbers of tagged individuals moving downstream (Cullen and McCarthy, 2003). Although discharge was an important variable in describing downstream migration events in the Shenandoah River, some American Eels also moved downstream under conditions when discharge was relatively low and had not changed for several days.

This study was the first multi-year study to evaluate environmental variables associated with downstream migration for American Eels. During this study, I was able to evaluate a relatively dry fall (2007), a moderately wet fall (2008) and a high discharge event in the fall (2009), and annual differences in river discharges during the fall months may have influenced migratory behavior of silver American Eels. In 2009, a large rainfall event increased discharge by $400 \%$ in mid-November resulting in nearly all American Eels to leave the river within seven days. In 2007, there were no substantial discharge peaks during the fall months and American Eels did not initiate downstream migrations until December when the first relatively high discharge event occurred. In 2008, there were some moderate peaks in discharge in the fall which resulted in some fall migration, but spring migrations also occurred that study year corresponding to peaks in spring discharges. The modeling also suggested a longer migration period during the first two study years with just over 100 days assigned to potential migration compared to the third year with only 46 days assigned to potential migration.

Water temperature is also a well-documented trigger to downstream migrations events (Haro et al., 2003, Durif et al., 2003). In this study, temperature was an important variable. All 
downstream migrations occurred between 3 and $23 C^{\circ}$, which was a slightly wider range than previously documented for the Shenandoah River (Euston et al., 1998). Most downstream passage events occurred with temperatures ranging between 5 and $12 \mathrm{C}^{\circ}$, which is also a wider range than the 9 to $13 C^{\circ}$ range reported earlier (Euston et al., 1998), but similar to temperatures reported for European Eels (Vøllestad et al., 1986; Acou et al., 2008; Reckordt et al., 2013). Modeling suggests that temperature appears to act as a qualifying factor for discharges in that discharge increases need to occur within the optimal temperature range (i.e. $6-14^{\circ} \mathrm{C}$ ) for European Eels to migrate downstream. On the Shenandoah, downstream migrations were uncommon in the spring after water temperatures reached $13^{\circ} \mathrm{C}$ and in the fall before water temperatures dropped to $13^{\circ} \mathrm{C}$, regardless of river discharge.

Lunar phase was not closely associated with downstream migrations in this study. More American Eels moved downstream during the darker phases of the moon, but migration occurred during all lunar phases. The addition of lunar phase to the logistic model did not improve model fit, indicating that it was not a significant factor associated with downstream silver American Eel migrations. Lack of correlation with lunar illumination and downstream migrations in American Eel was also observed in the Gulf of St. Lawrence (Cairns and Hooley, 2003). However, previous studies on American Eels, including one in the Shenandoah River, suggest that in absence of high discharge events, downstream migration will occur during the darker phases of the moon (Winn et al., 1975; Euston et al., 1998).

Developing models to describe downstream migration related to environmental variables has been attempted with several Anguilla spp. with varying levels of success. A model developed for European Eels using discharge and Julian day to predict the downstream 
migration was relatively successful, capturing an average of $79 \%$ of the actual downstream migration period (Durif and Elie, 2008). A study in New Zealand on Anguilla spp. determined that migration events could be predicted with $50 \%-89 \%$ accuracy based on water temperature and precipitation (Boubee et al., 2001). For the American Eel, Haro et al. (2003) developed a model to guide hydroelectric dam operators on the timing to implement turbine shutdown measures to protect downstream migrants. That model, based on rainfall events in the fall, would decrease turbine mortality by two-thirds to one-half. The model from the Shenandoah River American Eels, using discharge, proportional change in discharge, and water temperature was able to describe American Eel downstream migration events with a relatively high degree of accuracy ( $85 \%$ correct assignments). Based on the success of this model as well as models developed for other Anguilla spp., there is value in using environmental variables to determining when seasonal downstream protection measures should be implemented.

One potential problem with using this and other models previously described is that they do not define an endpoint in a migration season at which all migration has occurred. During the first two study years in the Shenandoah River, downstream migration events in the spring were common and the model was able to identify successful migration periods, regardless of time of year. In situations where downstream migration occurs over long periods of time, it would be appropriate to continue to implement protection measures through the spring months based on environmental variables. However, during the third year of the study, a high discharge event occurred in November and all but one of the tagged individual left the river during that time. Because essentially no tagged American Eels remained in the system after the November migration event, the environmental data for the winter and spring were 
not included in model development because no tagged individuals remained by which to measure additional passage events. River conditions in the spring of the third study year would have met criteria for likely downstream migration events and would have increased the number of passage days above the 46 that were represented here. To determine when protection measures are no longer warranted, an additional model would need to be developed evaluating the proportion of migration events that occurred under various combinations of environmental conditions to determine if there are conditions where all American Eels would have migrated downstream for the year.

Despite the inability to determine an ending point for downstream migration events, the association of environmental variables with downstream migrations events for American Eels could be useful in refining the nighttime turbine shutdown period at hydroelectric facilities on the Shenandoah River. Currently, turbine shutdowns are implemented September 15 to December 15 from 18:00-06:00 hours. Although the turbine shutdowns reduce turbine mortality (Chapter 4), the current date-only criteria used to determine when to implement shutdowns is not adequate to protect all downstream migrants, particularly for American Eels migrating during spring months. In addition, on many nights of the current shut-down period, American Eels did not migrate downstream, so turbines could have operated without impact to survival of downstream migrants. Ultimately understanding the environmental variables associated with downstream migration may aid in further refining the implementation of downstream protection measures for migrating American Eels. 


\section{References:}

Acou, A., P. Laffaille, A. Legault, and E. Feunteun. 2008. Migration pattern of silver eel (Anguilla anguilla, L.) in an obstructed river system. Ecology of Freshwater Fish 17:432-442.

Aho, K., D. Derryberry, and T. Peterson. 2014. Model selection for ecologists: the worldviews of AIC and BIC. Ecology 95:631-636.

Becker, B., F. Notermanns, C. Reuter, and H. Schuttrumpf. 2009. Development of a fish-friendly turbine-operation mode in run-of-river hydropower plants on the River Mosel. Hydrologie und Wasserbewirtschaftung 53:4-12.

Behrmann-Godel, J., and R. Eckmann. 2003. A preliminary telemetry study of the migration of silver European Eel (Anguilla anguilla L.) in the River Mosel, Germany. Ecology of Freshwater Fish 12:196-202.

Boubee, J. A., C. P. Mitchell, B. L. Chisnall, D. W. West, E. J. Bowman, and A. Haro. 2001. Factors regulating the downstream migration of mature eels (Anguilla spp.) and Aniwhenua Dam, Bay of Plenty, New Zealand. New Zealand Journal of Marine and Freshwater Research 35:121-134.

Bruijs, M. C. M., R. H. Hadderingh, U. Schwevers, B. Adam, U. Dumont, and H. V. Winter. 2009. Managing human impact on downstream migrating European Eel in the River Meuse. Pages 381-390 In: J. M. Casselman and D. K. Cairns (editors), Eels at the edge: science, status, and conservation concerns. American Fisheries Society, Symposium 58, Bethesda, Maryland, $449 \mathrm{p}$.

Cairns, D. K., and P. J. D. Hooley. 2003. Lunar cycles of American Eels in tidal waters of the southern Gulf of St. Lawrence, Canada. Pages 265-274 In: D. A. Dixon (editor), Biology, 
management, and protection of catadromous eels. American Fisheries Society, Symposium 33, Bethesda, Maryland, 388 p.

Cullen, P. and T. K. McCarthy. 2003. Hydrometric and meteorological factors affecting the seaward migration of silver eels (Anguilla anguilla, L.) in the lower River Shannon. Environmental Biology of Fishes 67:349-357.

Durif, C. M. F., and P. Elie. 2008. Predicting downstream migration of silver eels in a large river catchment based on commercial fishery data. Fisheries Management and Ecology $15: 127-137$.

Durif, C., P. Elie, C. Gosset, J. Rives, and F. Travade. 2003. Behavioral study of downstream migrating eels by radio-telemetry at a small hydroelectric power plant. Pages 343-356 In: D. A. Dixon (editor), Biology, management, and protection of catadromous eels. American Fisheries Society, Symposium 33, Bethesda, Maryland, 388 p.

Euston, E. T., D. E. Royer, C. L. Simons. 1998. American Eels and hydro plants: clues to eel passage. Hydro Review (August) 17:94-103.

Greiner, M., D. Pfeiffer, and R. M. Smith. 2000. Principles and practical application of the receiver-operating characteristic analysis for diagnostic tests. Preventative Veterinary Medicine 45:23-41.

Haro, A. 2003. Downstream migration of silver-phase anquillid eels. Pages 215-222 In: K. Aida, K. Tsukamoto, and K. Yamauchi (editors), Eel biology. Springer-Verlag, New York. 497 p. Haro, A., T. Castro-Santos, K. Whalen, G. Wippelhauser, and L. McLaughlin. 2003. Simulated effects of hydroelectric project regulation on mortality of American Eels. Pages 357-365 
In: D. A. Dixon (editor), Biology, management, and protection of catadromous eels. American Fisheries Society, Symposium 33, Bethesda, Maryland, 388 p.

Hosmer, D. W., and S. Lemeshow. 2000. Applied logistic regression. John Wiley \& Sons, New York, 392 p.

O'Brien, R. M. 2007. A caution regarding rules of thumb for variance inflation factors. Quality and Quantity 41:673-690.

Reckordt, M., C. Ubl, C. Wagner, J. Frankowski, and M. Dorow. 2013. Downstream migration dynamics of female and male silver eels (Anguilla anguilla L.) in the regulated German lowland Warnow River. Ecology of Freshwater Fish 23:7-20.

Smith, M. W., and J. W. Saunders. 1955. The American Eel in certain fresh waters of the Maritime Provinces of Canada. Journal of the Fisheries Research Board of Canada $12: 238-269$.

Trancart, T., A. Acou, E. De Oliveira, and E. Feunteun. 2013. Forecasting animal migrations using SARIMAX: an efficient means of reducing silver eel mortality cause by turbines. Endangered Species Research 21:181-190.

Travade, F., M. Larinier, S. Subra, P. Gomes, E. De-Oliveira. 2010. Behavior and passage of European silver eels (Anguilla anguilla) at a small hydropower plant during their downstream migration. Knowledge and Management of Aquatic Ecosystems 398:01 (doi: 10.1051/kmae/2010022).

Verbiest, H., A. Breukelaar, M. Ovidio, J. -C. Philippart, and C. Belpaire. 2012. Escapement success and patterns of downstream migration of female silver eel Anguilla anguilla in the River Meuse. Ecology of Freshwater Fish 21:395-403. 
Vøllestad, L. A., B. Jonsson, N. A. Hvidsten, T. F. Naesje, $\varnothing$. Haraldstad, and J. Ruud-Hansen. 1986. Environmental factors regulating the seaward migration of European silver eels (Anguilla anguilla). Canadian Journal of Fisheries and Aquatic Science 43:1909-1916.

Wantene, E. M., J. A. T. Boubee, and A. Haro. 2003. Downstream movement of mature eels in a hydroelectric reservoir in New Zealand. Pages 195-305 In: D. A. Dixon (editor), Biology, management, and protection of catadromous eels. American Fisheries Society, Symposium 33, Bethesda, Maryland, 388 p.

Winn, H. E., W. A. Richkus and L. K. Winn. 1975. Sexual dimorphism and natural movements of the American Eel (Anguilla rostrata) in Rhode Island streams and estuaries. Helgoländer Meeresuntersuchungen 27:156-166. 
Table 1. Environmental and other associated variables evaluated in logistic regression modeling to describe silver American Eel migrations on the Shenandoah River from 2007 through 2010.

\begin{tabular}{|c|c|c|}
\hline Variable & Acronym & Description \\
\hline Discharge & $\mathrm{D}$ & Discharge $\left(\mathrm{m}^{3} \mathrm{~s}^{-1}\right)$ measured at USGS gauging stations \\
\hline Log Discharge & LD & The $\log _{e}$ of the actual discharge value \\
\hline Discharge Proportion ( 2 day avg) & DP2 & $\begin{array}{l}\text { Proportion of current day's discharge against average } \\
\text { of previous two day's discharge }\end{array}$ \\
\hline Log Discharge Prop. (2 day avg) & LDP2 & $\begin{array}{l}\text { The } \log _{e} \text { of the proportion of current day's discharge } \\
\text { against average of previous two day's discharge }\end{array}$ \\
\hline Discharge Proportion ( 5 day avg) & DP5 & $\begin{array}{l}\text { Proportion or current day's discharge against average } \\
\text { of previous five day's discharge }\end{array}$ \\
\hline Log Discharge Prop. (5 day avg) & LDP5 & $\begin{array}{l}\text { The } \log _{10} \text { of the proportion of current day's discharge } \\
\text { against average of previous five day's discharge }\end{array}$ \\
\hline Water Temperature & TEMP & Temperature in ${ }^{\circ} \mathrm{C}$ measured at USGS gauging station \\
\hline Water Temperature (bin) & TEMPB & $\begin{array}{l}\text { Water Temperature divided into } 5 \text { bins: }(<6.0=\operatorname{Bin} 1 \text {, } \\
6.0-8.9=\operatorname{Bin} 2,9.0-13.9=\operatorname{Bin} 3,14.0-22.0=\operatorname{Bin} 4 \text {, } \\
>22=\operatorname{Bin} 5)\end{array}$ \\
\hline Lunar Illumination & LUN & $\begin{array}{l}\text { Fraction lunar illumination reported by US Naval } \\
\text { Observatory }\end{array}$ \\
\hline Season & SEA & $\begin{array}{l}\text { Season of year: Fall (Sep-Nov) }=1 \text {, Winter }(\text { Dec-Feb) }=2 \text {, } \\
\text { Spring (Mar-May) }=3 \text {, Summer (Jun-Aug) }=4\end{array}$ \\
\hline Modified Julian Date & MD & Sequential day of Study Year starting at August 1 \\
\hline Study Year & YR & Study year starting August 1 and ending July 31 \\
\hline Location & LOC & $\begin{array}{l}\text { Dam Location, Shenandoah }=1 \text {, Newport }=2 \text {, Luray }=3 \text {, } \\
\text { Warren }=4 \text {, and Millville }=5\end{array}$ \\
\hline
\end{tabular}


Table 2. Mean daily discharge during the study period and during downstream passage events for American Eels migrating past five dams on the Shenandoah River. Discharge data were taken from U.S. Geological Survey gauging stations at Lynwood, Luray, and Front Royal, Virginia, and Millville, West Virginia.

\begin{tabular}{lccccccc}
\hline & \multicolumn{3}{c}{ All Discharge $\left(\mathrm{m}^{3} \mathrm{~s}^{-1}\right)$} & & \multicolumn{3}{c}{ Discharge at Passage $\left(\mathrm{m}^{3} \mathrm{~s}^{-1}\right)$} \\
\cline { 3 - 5 } & Mean & Std. Dev. & Range & Mean & Std. Dev. & Range \\
\hline Shenandoah & 23.6 & 36.7 & $4.9-549$ & 47.0 & 93.6 & $4.9-549$ \\
Newport & 32.2 & 51.1 & $6.1-818$ & 41.9 & 67.9 & $7.4-507$ \\
Luray & 32.2 & 51.1 & $6.1-818$ & 63.4 & 64.3 & $7.4-507$ \\
Warren & 35.3 & 53.5 & $6.4-886$ & 69.9 & 45.1 & $7.7-151$ \\
Millville & 62.6 & 94.1 & $11.4-1150$ & 130.1 & 148.0 & $15.1-1150$ \\
\end{tabular}


Table 3. Logistic regression models considered for describing environmental variables associated with downstream migration events for silver American Eel on the Shenandoah River from 2007-2010.

\begin{tabular}{|c|c|c|c|c|}
\hline Model & Model ID & Log-Likelihood & $\mathrm{BIC}$ & $\triangle \mathrm{BIC}$ \\
\hline LD + LD5 + TEMPB & 1 & -776.2 & 1625 & 0 \\
\hline LD + LD5 + TEMPB + LDP5*LD & 2 & -773.7 & 1628 & 3 \\
\hline $\mathrm{LD}+\mathrm{LD} 5$ + TEMPB + MD & 3 & -776.0 & 1633 & 8 \\
\hline LD + LD5 + TEMPB + LUN & 4 & -776.0 & 1634 & 9 \\
\hline LD + LD5 + TEMPB + YR & 5 & -775.7 & 1641 & 16 \\
\hline LD + LD5 + TEMPB + SEA & 6 & -772.8 & 1645 & 20 \\
\hline LD + LD5 + TEMPB + LDP5*YR & 7 & -772.8 & 1654 & 29 \\
\hline LD + LD5 + TEMPB + LOC & 8 & -773.5 & 1655 & 30 \\
\hline LD + LD5 + TEMPB + LD*LOC & 9 & -769.0 & 1682 & 57 \\
\hline LDP5 + LD & 10 & -828.0 & 1692 & 67 \\
\hline LD + LD5 + TEMP & 11 & -824.8 & 1695 & 70 \\
\hline LDP5 + D & 12 & -843.7 & 1724 & 99 \\
\hline LDP5 & 13 & -874.3 & 1776 & 151 \\
\hline DP5 & 14 & -898.3 & 1824 & 199 \\
\hline LDP2 & 15 & -920.8 & 1869 & 244 \\
\hline DP2 & 16 & -937.4 & 1902 & 277 \\
\hline
\end{tabular}


Table 4. Parameter estimates for best-fitting logistic regression model $(\mathrm{BIC}=1625)$ using environmental variables to describe silver eel migrations past dams on the Shenandoah River from 2007-2010. The constant includes TempB 1. The odds ratios for TempB 2, 3, 4, and 5 are the odds of passage in those water temperature ranges compared to odds of passage within the range of water temperatures in TempB 1.

\begin{tabular}{lccccc}
\hline Variable & Estimate $(\beta)$ & SE $\beta$ & Z-value & $p$-value & (Odds \\
& & & & & $e^{\beta}$ \\
& & & & & Ratio) \\
Constant & -7.967 & 0.4228 & -18.45 & $<0.001$ & NA \\
LD & 0.9447 & 0.1296 & 7.289 & $<0.001$ & 2.57 \\
LDP5 & 2.332 & 0.2005 & 11.63 & $<0.001$ & 10.3 \\
TEMPB 2 & 1.885 & 0.2651 & 7.109 & $<0.001$ & 6.58 \\
TEMPB 3 & 1.824 & 0.2202 & 8.285 & $<0.001$ & 6.20 \\
TEMPB 4 & 0.9444 & 0.2899 & 3.258 & 0.001 & 2.57 \\
\hline
\end{tabular}


Figure 1. Shenandoah River watershed and location of five hydroelectric dams monitored with stationary radio telemetry for silver American Eel passage. All collection and tagging occurred upstream of the Luray Dam.

Figure 2. Percent of downstream American Eel passage events at five dams on the Shenandoah River from 2007 through 2010. Eel passage events were pooled for all dams by day and discharge data were taken from U.S. Geological Survey gauging station at the Luray Dam. Note scales are different between graphs.

Figure 3. Water temperature during downstream passage events for American Eel migrating past five hydroelectric dams on the Shenandoah River from 2007 through 2010. Water temperature data were taken from U.S. Geological Survey gauging station at the Luray Dam. 


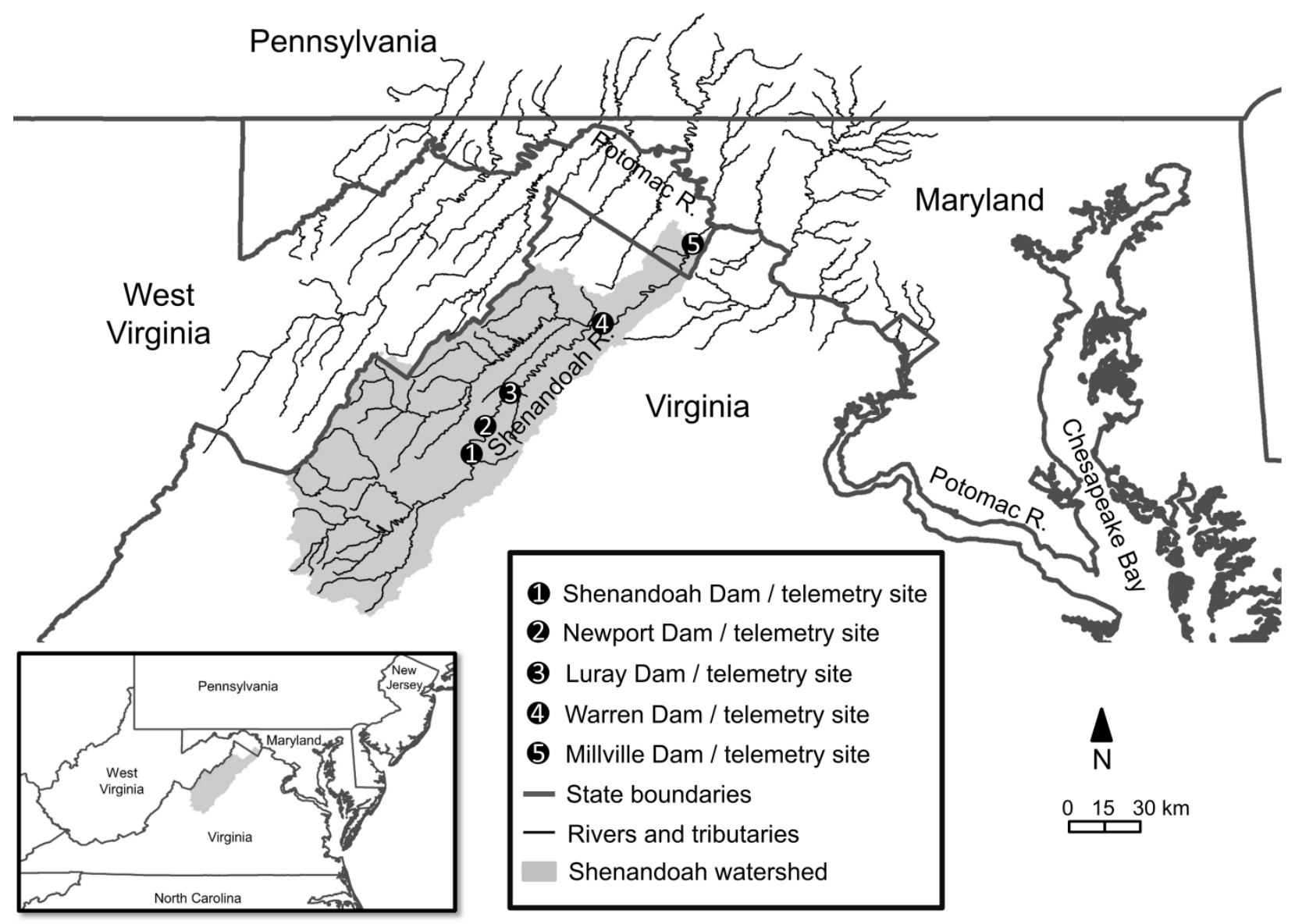



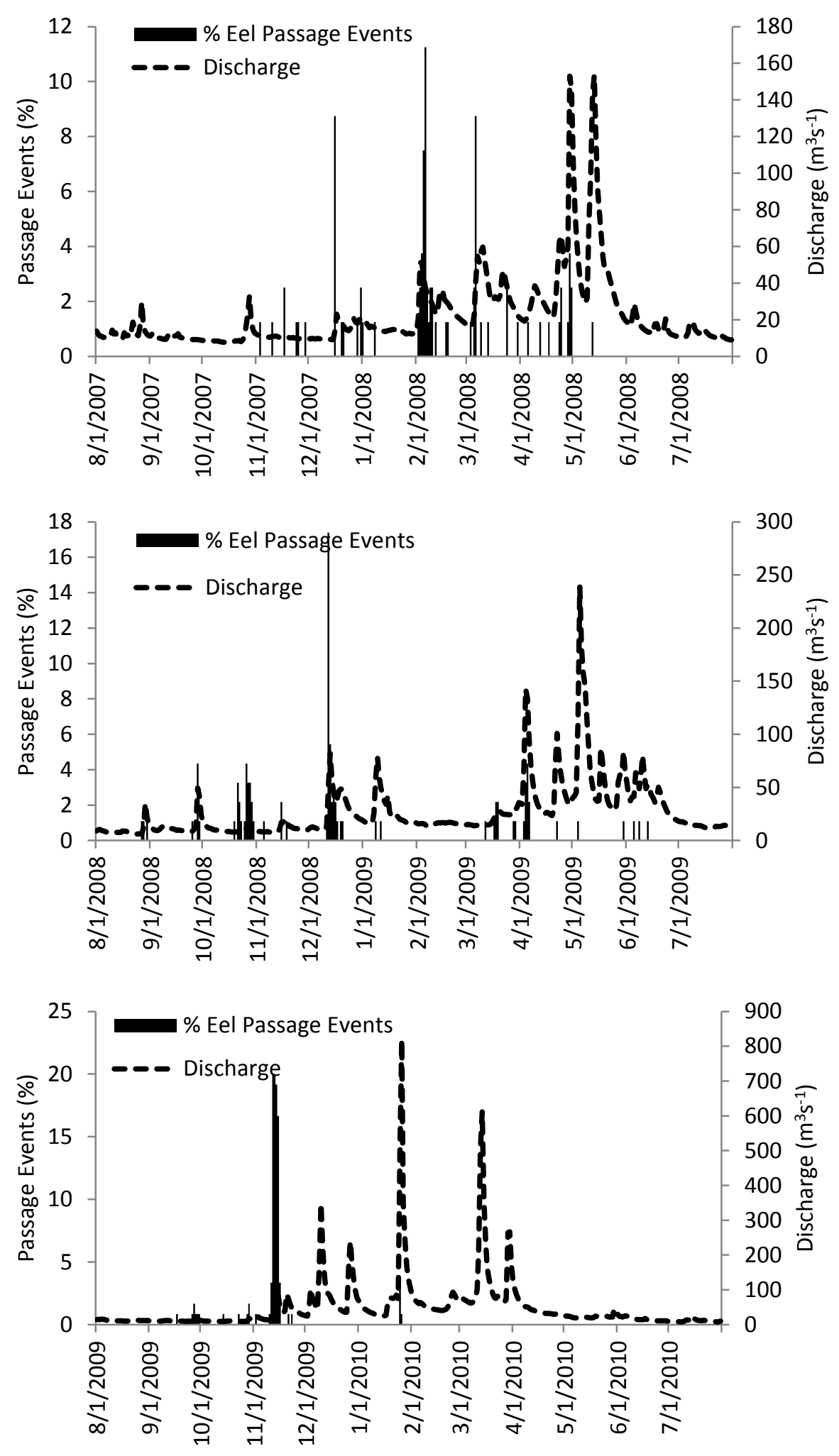


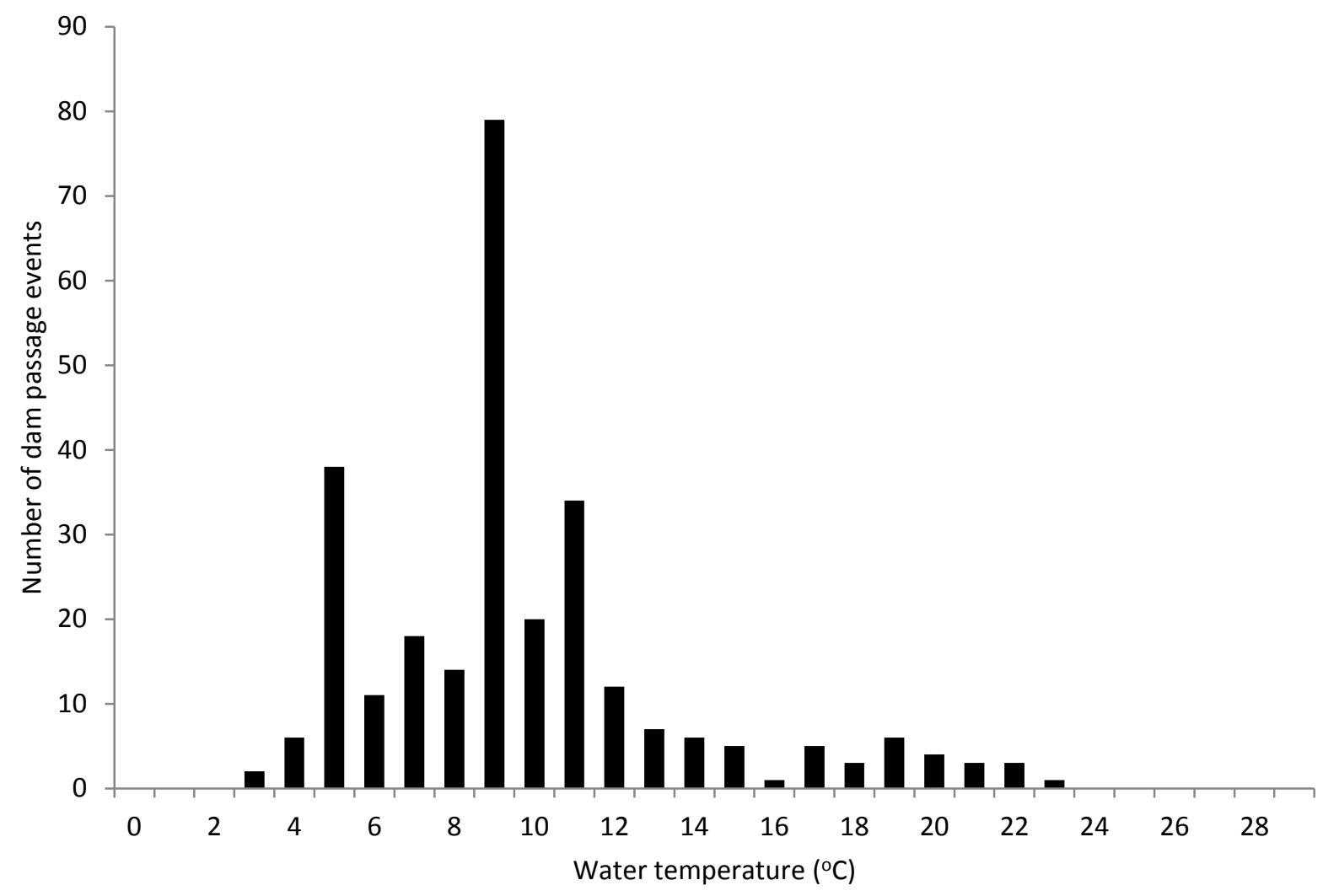


Chapter 4-Passage method, turbine mortality, and migratory delay of silver American Eels (Anguilla rostrata) at five hydroelectric dams on the Shenandoah River

Abstract:

Hydroelectric dams can impact downstream migrations of silver American Eels (Anguilla rostrata) through migratory delays and turbine mortality. A radio-telemetry study on American Eels was conducted to determine impacts of five hydroelectric dams located over a $195 \mathrm{~km}$ stretch of the Shenandoah River in Virginia and West Virginia from fall 2007 through summer 2010. A total of 96 (mean length $85.4 \mathrm{~cm}$ ) radio-tagged individuals migrated downstream during the study. Over half (58\%) of dam passage events occurred within $1 \mathrm{~h}$ of reaching a dam and most (81\%) occurred within $24 \mathrm{~h}$ of reaching the dam. Two-thirds of the dam passage events occurred via spill and the remaining passage events were through turbines. Passage method (spill vs. turbine) did not influence migratory delay at dams (median $0.73 \mathrm{~h}$ vs. $0.77 \mathrm{~h}$, respectively). During periods of high river discharge (greater than $5 x$ median), migratory delays at dams were shorter (median $0.33 \mathrm{~h}$ ) and American Eels were more likely to spill over the dam (79\%) compared to times during low river discharge (less than 2x median, $15 \mathrm{~h}$ median delay, 26\% passage via spill). Twenty-eight American Eels experienced turbine mortality, which occurred at all five dams. Mortality rates for eels passing through turbines ranged from $16 \%$ to $41 \%$ at individual dams. Overall project mortality rates ranged from $3 \%$ to $14 \%$ during the study. Nighttime turbine shutdowns implemented 15 September-15 December, 18:00-06:00 hours encompassed $50 \%$ of the total downstream passage events in the study. Implementation of the seasonal turbine shutdown period reduced cumulative mortality for American Eels 
passing all five dams from $63 \%$ to $37 \%$. Modifying the turbine shutdown period to encompass more dates in the spring and potentially have them linked to environmental variable triggers could provide more protection to downstream migrating American Eels.

Introduction:

The population of American Eel (Anguilla rostrata) has been declining in recent decades (ASMFC, 2012), and dams are likely one of the contributing factors. Dams not only limit access to upstream habitat for immature American Eels, but also affect downstream migration of adults which ultimately impacts survival and reproductive success. For downstream migrants, dams can be complete or partial barriers for passage. Dams with intermittent or highly controlled water releases can be complete barriers to downstream migration, particularly if water releases do not coincide with the timing of outmigration (Feunteun et al., 2000; Acou et al., 2008). In rivers where downstream access is available, either through hydroelectric turbines, spill, or other means, migrant American Eels may still experience extended search times for downstream passage routes (Haro and Castro-Santos, 2000; Carr and Whoriskey, 2008; Brown et al., 2009; Piper et al., 2013). If fecund females are not able to locate a downstream passage route in a timely manner, then those individuals may not reach the Sargasso Sea during the spawning season and thus not contribute to the spawning population.

In addition to migratory delays, dams can also cause injury and mortality for downstream migrants. For non-hydroelectric dams, American Eels typically either spill over the top of the dam or pass downstream through spill gates which can cause injury or mortality from impact or changes in water pressure (Wantene and Boubée, 2005; Calles et al., 2010). 
Hydroelectric dams provide an additional downstream passage route for eels through turbines, which cause injury or mortality through blade strikes. Turbine mortality rates vary widely between dams, ranging from $6 \%$ to $100 \%$ (Jansen et al., 2007; Carr and Whoriskey, 2008; Bruijs et al., 2009; Calles et al., 2010; Pedersen et al., 2012, Buysse et al. 2014). Many factors can effect turbine mortality rates, including turbine type, speed, head, etc. (EPRI, 1999), as well as the size of the migrating eels (Jansen et al., 2007; Calles et al., 2010), and it is difficult to predict turbine mortality rates based on attributes of a hydroelectric dam.

Several methods have been used to reduce or eliminate turbine injury and mortality of silver eels at hydroelectric dams. In Europe and New Zealand, trap and transport have been implemented to collect silver eels and transport them around dams to avoid encountering dams and turbines (Boubée et al., 2003; Klein Breteler et al., 2007; McCarthy et al., 2008). Screens have also been used to divert eels away from turbines and into bypass chutes for safe downstream passage (EPRI, 1999; Gossett et al., 2005). Timed water releases have been attempted when eels are suspected to be migrating downstream so that individuals can pass downstream without passing through turbines (Boubée and Williams, 2006). Turbine shutdowns have been implemented in Maine and Virginia where a hydroelectric dam ceases turbine operation during suspected silver American Eel migration times so that individuals can spill over dams or pass downstream through bypass chutes (Federal Energy Regulatory Commission Project Numbers 2897, 2932, 2941, 2931, 2942). All of these methods, which have varying success in protecting migrating eels, require site-specific evaluation once implemented at a hydroelectric dam. 
Downstream passage of migrating American Eels was evaluated relative to five hydroelectric dams on the Shenandoah River in Virginia and West Virginia as well as two nonhydroelectric dams on the Potomac River. Allegheny Energy Supply (PE Hydro Generation, LLC), owner of all five hydroelectric dams, manipulated hydroelectric generation through seasonal nighttime turbine shutdowns as a method to decrease turbine mortality during the assumed peak silver American Eel migration period. This study evaluated turbine mortality and migratory delays of downstream migrant American Eels, as well as evaluated impact of the nighttime turbine shutdown period for protecting downstream migrants. The study also considered the cumulative impacts of multiple hydroelectric dams on survival of large female American Eels during outmigration from the upper Shenandoah River watershed and through a portion of the middle Potomac River.

Methods:

Site Description

The Shenandoah River, the largest tributary of the Potomac River, has a watershed area of $7870 \mathrm{~km}^{2}$. The river flows north from its headwaters in central Virginia to its confluence with the Potomac River near Harpers Ferry, West Virginia. There are five hydroelectric dams on the Shenandoah River (Figure 1). The Shenandoah, Newport, and Luray dams are located on the South Fork of the Shenandoah River in Virginia. The remaining two dams, Warren and Millville, are located on the Shenandoah River in Virginia and West Virginia, respectively. The distance between the uppermost (Shenandoah) and lowermost (Millville) dams is $195 \mathrm{rkm}$. The Shenandoah River flows into the Potomac River at rkm 282 from the Potomac River mouth. 
There are no hydroelectric dams in the Potomac River downstream of the confluence of the Shenandoah River; however the 4.6 m high Washington Aqueduct Dam at Great Falls (rkm 206) diverts water into the Washington Aqueduct system to supply drinking water to the District of Columbia. The Washington Aqueduct is a $19 \mathrm{~km}$ conduit that empties into a settlement basin at Dalecarlia Reservoir and associated water treatment facility. Downstream of the Washington Aqueduct Dam on the Potomac River is the Little Falls Dam (rkm 192). The Little Falls Dam (3.7 $\mathrm{m}$ high) is the last dam on the Potomac River and it functions as an emergency pumping station for Dalecarlia Reservoir, although no pumping occurred directly from the Potomac River at this location during this study.

All hydroelectric dams on the Shenandoah River are run-of-the-river and must maintain a $2.5 \mathrm{~cm}$ minimum spill over the dam. The dams range in height from $4.5-8.7 \mathrm{~m}$ and rated project capacity ranges from $0.75-2.83 \mathrm{MW}$. The four lowermost dams have three vertical Francis turbine units and the Shenandoah Dam has one Francis turbine and three propeller turbines. All of the dams have a $7.6 \mathrm{~cm}$ trash rack spacing to reduce large debris from entering the turbines, but none have downstream protection or guidance measures for fish. Ladders for upstream American Eel migration have been recently installed on the three lowermost dams and American Eels are present in the watershed above all five dams. American Eels moving downstream at all five dams are expected to either spill over the top of the dam or travel through the powerhouse and through the turbines. The hydroelectric company currently implements turbine shutdowns from 15 September through 15 December between 18:00 and 06:00 hours to protect downstream migrating silver American Eels. 


\section{Fish Collection}

American Eels were collected primarily by boat electrofishing, but also by backpack electrofishing. Boat electrofishing was used in impounded areas of the South Fork Shenandoah River in Virginia near the towns of Shenandoah, Newport, and Luray, as well as in deeper sections of the river at Island Ford, Port Republic, and the Rt. 211 Bridge crossing. In wadeable tributaries upstream of the Shenandoah Dam, American Eels were captured with backpack electrofishing (Smith-Root, model LR-24). All American Eels were tagged between September and December in years 2007, 2008 and 2009.

\section{Tags and Tagging Methods}

American Eels were tagged with cylindrically-shaped coded radio tags (either F1835 or F1830, Advanced Telemetry Systems, Inc., MN). Both tag models had $30 \mathrm{~cm}$ external whip antennas. The battery life expectancy of the larger F1835 tag (18 month, $14 \mathrm{~g}$ weight, $18 \mathrm{~mm}$ width by $42 \mathrm{~mm}$ length) exceeded that of the smaller F1830 tag ( 4.5 month, $11 \mathrm{~g}, 12 \mathrm{~mm}$ by 53 $\mathrm{mm}$ ). Both tag types had a pulse rate of $45.8 \mathrm{ppm}$ and a pulse width of $34 \mathrm{~ms}$. The F1830 tags continuously emitted a signal, while the F1835 tags were on a repeating duty cycle of $12 \mathrm{~s}$ on and $12 \mathrm{~s}$ off. The tags covered a total of six frequencies during the first year of the study and were reduced to four frequencies during the last two years.

Radio tags were surgically-implanted into all silver and some yellow American Eels (yellow eels $>735 \mathrm{~mm} \mathrm{TL}$ ) within 1-2 h of capture. American Eels were sedated for about 15 min prior to surgery using MS-222 (concentration of $500 \mathrm{mg} \mathrm{L}^{-1}$ ). Radio tags were implanted through a lateral incision made on the ventral surface of the American Eel about $10 \mathrm{~cm}$ anterior to the anal opening. After making the initial incision, a catheter was inserted through the 
ventral surface of the fish about $3 \mathrm{~cm}$ posterior to the incision site. The radio tag was implanted through the incision in the body cavity and the radio antenna was passed through the catheter so that the antenna was not exiting the fish at the site of the incision (Ross and Kleiner, 1982). Once the tag was implanted, four sutures (Ethicon monofilament) closed the incision. The surgery took about 5 min to complete. While sedated, individuals were measured for total length, eye height and width, and also weighed, scanned for passive integrated transponder (PIT) tag, tagged with a PIT tag, and assigned a color phase (silver, pre-silver, or yellow). Silver American Eels were identified by having thicker abdominal musculature, larger lateral line pores, relatively larger eyes, and lighter margins on the pectoral fins compared to immature (yellow) American Eels (McGrath et al., 2003). A pre-silver phase was assigned to some individuals that showed characteristics of both silver and yellow eels. After tagging, individuals were placed in an aerated container of fresh water for recovery from the sedative. Fish were held for observation for up to $1 \mathrm{~h}$ prior to being released near their capture location.

\section{Radio Telemetry Monitoring}

In 2007, 14 radio receivers (Advanced Telemetry Systems, R4500C) were deployed between the Millville, Warren, Luray, Shenandoah, and Little Falls dams as well as the Dalecarlia Reservoir. Six receivers were added to the system in 2008 to evaluate the Newport Dam and to increase resolution at Warren and Luray dams. All stationary receiver locations were programmed to continuously scan for tag frequencies with a 24 s time out, a 24 s scan time, and a store rate of $3 \mathrm{~min}$.

Four different types of receiver antennas were used to help determine timing and location of downstream American Eel passage in the study. A 6-element yagi aerial antenna was 
mounted on a guard rail near the powerhouse building at each dam. These antennas identified tags at approximately $1 \mathrm{~km}$ distance and were used to determine when the tagged individuals entered the vicinity of the monitoring location. An aerial dipole was used at the Millville Dam powerhouse to isolate tag signals in the tailrace (Figure 2). Underwater dipoles (constructed after Beeman et al., 2004) and stripped coax cable antennas were used at all dams with the exception of the Shenandoah Dam to determine fine-scale movements through the hydroelectric stations.

Antenna inputs were combined at locations where multiple similar antennas were attached to one receiver. This allowed for scanning frequencies on multiple antennas with one receiver. In locations where American Eels were predicted to move through quickly (draft pits and tailraces), two receivers were used and the number of frequencies scanned was divided between the two receivers, decreasing the amount of time between scans for a frequency. The gain was set to maximum (10) for the aerial yagi antennas, and reduced for necessary location resolution (4 to 6) among underwater and aerial dipole antennas. Data from the receivers were downloaded at least two times per month during the fall and one time per month through the reminder of the study period.

Mobile tracking was conducted at least one time per month in the vicinity of the dams to determine location of tagged individuals, particularly for those thought to be in the dam tailraces. American Eels were determined to have experienced turbine mortality if they were detected in the dam tailrace area for more than $3 \mathrm{~d}$. Additional mobile tracking was conducted at least one time per study year to determine locations of individuals that did not progress to the next downstream dam. 


\section{River Discharge}

Mean daily river discharge data were acquired from the U.S. Geological Survey's Water Watch website (http://water.usgs.gov/waterwatch). Discharge data from the gauging stations located on the South Fork and the mainstem of the Shenandoah River were used to determine if river discharge was associated with either migratory delays or method of passage at a dam. River discharge data were used from the Lynwood station (for Shenandoah Dam), the Luray station (for Luray and Newport dams), the Front Royal station (for Warren Dam), and the Millville station (for Millville Dam).

\section{Data Analysis}

American Eel migration was monitored continuously from September 2007 through August 2010. Data were divided into three 1-year periods for analysis starting on date 1 September and ending on 31 August of the following year. Telemetry data were evaluated for each individual fish at each dam. The date and time of first arrival at the dam, time of passage at the dam, method of passage at the dam, and survival or mortality for each passage event were derived from the telemetry data. Passage via turbines was determined if the American Eel was detected in the draft pits and/or the tailrace. Spill was assigned as the passage method if detections were made on the aerial antennas at the dam and no detections were made by the telemetry receivers located in the powerhouse. Survival was assumed if duration of detection in the tailrace receivers was less than $3 \mathrm{~d}$.

Migratory delay was determined by the difference in arrival and passage time at each dam. First passage events for individuals tagged in the Shenandoah, Newport, and Luray Impoundments were removed from analysis because I was not able to determine if tagged 
American Eels were residents of the impoundment near the dam or actively migrating. Passage data from Newport Dam for the first study year were not used in the delay analysis because there was no telemetry equipment at that location to monitor when exactly individuals passed. Statistical differences in migratory delay were evaluated using a linear mixed effects model with repeated measures and unbalanced design (nIme, $R$ version 2.15.1). Significant differences were determined if $p$-values in the model were less than 0.05. Delay data were log transformed in order to normalize the data prior to statistical analysis.

To determine if discharge was associated with dam passage method and migratory delay, mean daily discharge during a downstream passage event $\left(d_{p}\right)$ was converted into a proportion of median discharge $\left(P_{p}\right)$ from the overall study. Median discharge $\left(d_{m}\right)$ values were as follows: $12.3 \mathrm{~m}^{3} \mathrm{~s}^{-1}$ at Shenandoah Dam, $16.6 \mathrm{~m}^{3} \mathrm{~s}^{-1}$ at Newport and Luray dams, $18.0 \mathrm{~m}^{3} \mathrm{~s}^{-1}$ at Warren Dam and $32.0 \mathrm{~m}^{3} \mathrm{~s}^{-1}$ at Millville Dam.

$$
P_{p}=\frac{d_{p}}{d_{m}}
$$

The proportions of discharge during dam passage events $\left(P_{p}\right)$ were then log transformed. The transformed proportions were analyzed using a linear mixed effect model with repeated measures to determine if passage method and migratory delay were associated with river discharge. The mean daily river discharge value for the date of arrival was used when conducting the delay analysis. For passage method analysis, only individuals that passed a dam during regular hydroelectric operation (turbines running) were used, and passage events were removed from analysis during times when the proportion of discharge was at least 20 times higher than the median river discharge, because turbines were shut down during these periods of extreme high discharges. 
Turbine mortality rates were calculated for each dam during monitoring periods when method of passage was known. Turbine mortality rates were calculated by dividing the number of eels that suffered immediate turbine mortality by the total number of eels known to pass through turbines. Overall dam mortality rates were calculated by dividing the number of eels that suffered immediate turbine mortality by the total number of eels that passed the dam via any method. The $95 \%$ confidence limits for all mortality rates were calculated using a binomial profile likelihood estimate.

Results:

One hundred forty-five of 326 American Eels captured in the Shenandoah River watershed were radio-tagged. Seventy-two were tagged in 2007, 43 were tagged in 2008, and 30 were tagged in 2009. Sixty radio-tagged individuals were released upstream of the Shenandoah Dam, 34 were released between the Newport and Shenandoah dams, and 51 were released between Luray and Newport dams. Ninety-two radio-tagged American Eels were silver phase, 25 were large yellow phase, and 28 were pre-silver phase. Radio-tagged American Eels were $85.4 \mathrm{~cm} \pm 0.45 \mathrm{~cm}$ TL $($ mean $\pm \mathrm{SE}$, range $72.0-101.8 \mathrm{~cm}$ ) and weighed $1.39 \mathrm{~kg} \pm 0.025 \mathrm{~kg}$ (range $0.66-2.66 \mathrm{~kg}$ ).

In 2007, 43 American Eels were tagged and released with the smaller model F1830 radio tags. The remaining individuals in 2007 through 2009 were tagged and released with the larger model F1835 tags. Tag loss or tagging mortality rates were not directly measured in this study. However, two recaptured individuals, which had scars from previous tag implantation surgery, apparently lost their tags. One yellow American Eel $(770 \mathrm{~mm} \mathrm{TL})$ with a large abdominal tumor 
was tagged but did not survive surgery. Two tagged individuals were sluggish upon release, and two additional tagged individuals may have experienced spinal damage during electrofishing based on erratic swimming at release. The remaining 141 tagged American Eels actively swam away from the release locations with no apparent immediate capture related injuries. Analyses were conducted on fish that passed dams during the study, and any American Eels that did not display downstream migratory activity (i.e. passed a dam), or that may have suffered mortality or tag loss prior to passing any dams were not included in the results.

Radio detection probability at the stationary receivers in the Shenandoah River was high in the study. Radio-tagged American Eels were detected at each Shenandoah River dam they passed during the study, with no individuals passing a dam without having at least one detection on a stationary receiver. Detection probability in the powerhouse was also high, with no individuals being detected in dam tailraces without first being detected in the powerhouse near the turbines. Detection probability at the Potomac River Stations was not evaluated, but was not $100 \%$ at the Dalecarlia Reservoir as at least one tagged American Eel passed that location without being detected by the stationary equipment.

During the study, 96 radio-tagged American Eels moved downstream and passed at least one dam. Eighty-one of the 96 American Eels were silver phase when tagged and 78 of those individuals migrated downstream during the same study year as tagging. The remaining three silver phase American Eels initiated downstream migrations during the fall about one year after being tagged. Eight American Eels (seven pre-silver and one yellow phase) migrated downstream in the same study year as being tagged. Two pre-silver and five yellow phase individuals made downstream migrations about one year after being tagged, and the maturity 
stages of these individuals were unknown at the time of their migrations. A total of 293 dam passage events were recorded for radio-tagged American Eels.

Depending on release location, American Eels were expected to pass between three and five dams during downstream migration in the Shenandoah River. Of the 96 American Eels that moved downstream past dams in the study, 18 passed just one dam, 12 passed two dams, 29 passed three dams, 20 passed four dams, and 17 passed all five dams. A total of 53 (55\%) American Eels successfully migrated past the last dam on the Shenandoah River. Twenty-eight individuals (29\%) did not complete migrations out of the Shenandoah River because of suspected turbine related mortality. Fifteen (16\%) of the remaining 96 American Eels did not complete migrations out of the Shenandoah River prior to the end of battery life and/or loss of the radio tag.

Migratory Delay

Dams may have caused some delays in downstream migration. In $58 \%$ of passage events, individuals passed dams within $1 \mathrm{~h}$ of first detection at the dam (Table 1). Most (81\%) passage events occurred within $24 \mathrm{~h}$ of first arrival at a dam. Nearly all (91\%) American Eels passed a dam within $10 \mathrm{~d}$ of first arrival. The longest period between first arrival at a dam and passage was $157 \mathrm{~d}$, which occurred at the Luray Dam. Median delay times for the Shenandoah, Warren, and Millville dams were less than $1 \mathrm{~h}$ and 1.22 hours at Newport Dam (Table 1 ). Median delay at the Luray Dam (12.2 h) was significantly longer than the Newport $(\beta=-0.602$, $S E=0.290, p=0.04)$, Warren $(\beta=-0.995, S E=0.212, p<0.01)$, and Millville dams $(\beta=-0.902$, $S E=0.216, p<0.01)$ (Table 1). The delay at Luray Dam was not significantly different $(\beta=-0.817$, $\mathrm{SE}=0.448, \mathrm{p}=0.66$ ) from the Shenandoah Dam, where median delay time was $0.3 \mathrm{~h}$. The lack of 
statistical difference in delay between the two locations is likely due to highly variable delay times combined with the small sample size $(n=7)$ at the Shenandoah Dam.

\section{Passage Method}

Method of dam passage (spill vs. turbine) was determined for 256 of the 293 passage events. During the three-year study, 171 (67\%) passage events occurred via spill and 85 (33\%) were through turbines. A similar proportion of American Eels passed via spill at the Newport, Luray, Warren, and Millville dams (74\%, 65\%, 68\%, and 54\% respectively). Shenandoah Dam was not monitored in a way to determine definitive turbine passage; therefore passage method at that dam was unknown. Individual fish did not always use the same passage method at each dam. A total of 59 American Eels (61\%) passed through turbines at least one time during the study. Thirty-three (56\%) of the 59 individuals that passed through turbines during the study also passed dams by spilling. The maximum number of locations for turbine passage for one individual was three $(n=6)$, however most (66\%) American Eels that passed through turbines only did so at one location.

The method of passage was not significantly associated with migratory delays $(\beta=0.653$, $\mathrm{SE}=1.52, \mathrm{p}=0.31)$. Median delay time with turbine passage was $0.77 \mathrm{~h}(\mathrm{n}=59)$, with most $(80 \%)$ American Eels passing through the turbines within $24 \mathrm{~h}$ of reaching the dam. A similar proportion (80\%) of American Eels passing via spill made their downstream migrations within $24 \mathrm{~h}$, and the median delay time for individuals passing by spill was $0.73 \mathrm{~h}(\mathrm{n}=127)$. River Discharge Associated With Passage Method and Migratory Delay

There was a significant relationship between river discharge and passage method and migratory delay. American Eels were more likely to pass dams through turbines during low river 
discharge and spill over dams during high river discharge (68 individuals, 118 events, $\beta=0.579$, $\mathrm{SE}=1.13, \mathrm{p}<0.0001)$. During times of relatively low river discharge (less than double the median discharge during the study), $74 \%$ of passage events occurred through turbines compared to $26 \%$ via spill. During periods of relatively high river discharge (greater than five times the median discharge during the study), $79 \%$ of passage events occurred via spill compared to $21 \%$ via turbines. Although some American Eels did move quickly past dams during periods of relatively low discharge, nearly all individuals moved past dams in less than $1 \mathrm{~h}$ when discharge was at least twice as high as the median discharge (Table 2). Overall, the delay times were significantly longer for American Eels that arrived at dams during periods of lower river discharge (77 individuals, 197 passage events, $\beta=0.999, \mathrm{SE}=1.00, \mathrm{p}=0.0018$ ).

\section{Turbine Mortality Rates}

Twenty-eight American Eels (29\%) that passed dams in the study were suspected to have experienced immediate turbine mortality. Suspected turbine mortality occurred at all five dams and mortality was verified for one radio-tagged and three untagged American Eels at Luray Dam through carcass retrieval. No immediate mortality resulting from spill at any of the dams was observed. Delayed mortality that occurred from injuries sustained from turbine passage or spill during the study was not evaluated, but some American Eels did not complete downstream migrations before their radio tags ceased working. Those individuals that did not complete migration during the study may have experienced delayed mortality, tag loss, or completed downstream migration at a later date.

Forty-seven percent of the 59 American Eels that passed through turbines at least one time during the study experienced turbine mortality. Turbine mortality rates were calculated 
for 78 events where American Eels passed through turbines (Table 3). Turbine mortality rates ranged from $16 \%$ (95\% confidence limits $5 \%$ to $36 \%$, Warren Dam) to $41 \%$ ( $95 \%$ confidence limits $24 \%$ to $59 \%$, Luray Dam). When considering American Eels passing a hydroelectric dam during all project operations (including turbine shutdowns) and all passage methods (including spill), overall mortalities for each dam ranged from 3\% (95\% confidence limits $0 \%$ to $12 \%$ ) at the Shenandoah Dam to $14 \%$ (95\% confidence limits $7 \%$ to $24 \%$ ) at the Newport Dam (Table 4). Overall cumulative mortality from the study was $37 \%$ (95\% confidence limits $20 \%$ to $61 \%$ ) for American Eels migrating downstream past all five dams on the Shenandoah River. Seasonal and Daily Timing of Migrations

American Eels moved downstream past dams in every month of the year except July. Peak migration time differed for each of the three study years (1 September to 31 August) (Figure 3). In 2007/2008, peak migrations occurred in February and March. In 2008/2009, peak migrations occurred in October and December. During 2009/2010, nearly all migrations occurred in November. For all years combined, peak migration occurred in November and December. Sixty-seven percent of migration events occurred on the dates between 15 September and 15 December.

Migration past dams occurred during every hour of the day, but most migrations occurred in the evening and at night (Figure 4). A total of $87 \%$ of migrations occurred between 17:00 and 05:00, and 81\% percent of the passage events occurred between 18:00 and 06:00. Impact of Turbine Shutdowns

A total of 120 (50\%) of the 242 dam passage events with known date and time of passage occurred while turbines were shutdown to protect downstream migrating American 
Eels (15 September-15 December, 18:00-06:00 hours). During the nighttime shutdowns, six (5\%) passage events occurred through the turbines and the remaining events $(n=124)$ occurred via spill. Turbine shutdowns reduced passage through turbines from $65 \%$ during regular operation to $5 \%$ during turbine shutdowns.

The six American Eels that passed through turbines during shutdowns did so at the Newport, Luray and Millville dams. The two individuals at Luray Dam traveled downstream between 18:00 and 20:00 hours, and both experienced turbine mortality. The three individuals at Newport Dam that traveled downstream through the turbines did so between 19:00 and 00:00 hours, and all three of those survived. The final individual traveled through the turbines at Millville Dam at 22:00 hours also survived. All six turbine passage events during turbine shutdowns occurred on different dates in the study. I was unable to determine whether the turbine shutdowns had delayed starts on those occasions, if turbine shutdowns did not occur at all on the evenings, or if American Eels were able to pass through the turbines when they were not operating.

Passage through turbines and overall project mortality were reduced during nighttime shutdowns (Table 5). Overall project mortality rates at each of the five dams ranged from $0 \%$ to $6 \%$ during turbine shutdowns compared to a range of $6 \%$ to $38 \%$ for American Eels that passed dams during regular operating conditions. The resulting cumulative mortality for American Eels traveling past all five dams during the turbine shutdowns was $7 \%$ (95\% confidence limit $2 \%$ to $41 \%$ ) compared to $63 \%$ (95\% confidence limit 33\% to $88 \%$ ) for American Eels migrating during regular operation. 
Telemetry data indicated that American Eels did spend time moving between turbine intakes areas and the dam face during the turbine shutdowns, but shutdowns were not significantly associated with migratory delays $(\beta=1.28, S E=1.47, p=0.51)$. Turbine shutdowns also did not appear to shift migrations through turbines to morning hours after turbines operations were re-started (Figure 4). The time of day American Eels moved downstream peaked between 17:00-18:00 during turbine shutdowns and between 18:00-19:00 during regular operation.

\section{Downstream Migration in the Potomac River}

Of the 53 American Eels that successfully passed the Millville Dam, 23 passed the Little Falls Dam, three were entrained into the Washington Aqueduct System, nine did not complete migrations out of the Potomac River, and 18 were not detected at any location after passing the Millville Dam. The three American Eels ( $5 \%$ of what passed Millville Dam) which were entrained into the Washington Aqueduct Intake at Great Falls traveled $19 \mathrm{~km}$ through the conduit before being detected in the Dalecarlia Reservoir. With the potential for missed detections, the number of American Eel that may have been entrained into the Aqueduct could have been as high as $40 \%(n=21)$ of those American Eels that were passing downstream in the Potomac River. Once American Eels were entrained into the Aqueduct, although alive, were not able to gain access back to the Potomac River, so they were not able to complete their spawning migration.

The pumping station associated with Little Falls Dam is capable of pumping water directly from the Potomac River into the adjacent Dalecarlia Reservoir. During the study, no American Eels were entrained through the Little Falls pumping station into Dalecarlia Reservoir. In addition, the Little Falls Dam did not appear to cause long migratory delay as 19 of the 23 
American Eels that passed that location did so within 10 min of being detected at the location. Of the remaining four American Eels, three passed in less than $2 \mathrm{~h}$ and one passed $22 \mathrm{~h}$ after first detection. Of the 96 American Eels that migrated downstream during the study, a total of ( $n=23,24 \%)$ were detected as successfully passing the Little Falls Dam. With the potential for missed detections at that location $(n=18)$, the total number that could have potentially passed the Little Falls Dam from the Shenandoah River study could have been as high as $43 \%$.

\section{Discussion:}

Turbine mortality of American Eels occurred at all five hydroelectric dams on the Shenandoah River during the study. The rates of overall project mortality at each dam were variable ranging from $3 \%$ to $14 \%$ under current operational conditions which included seasonal nighttime shutdowns. When only considering passage during regular operation (no turbine shutdowns), overall project mortality rates at each of the dams were between $6 \%$ and $38 \%$. Mortality when passing through turbines ranged from $16 \%$ to $41 \%$ at the four of the five dams where turbine mortality rates were measured. Studies on European Eels ( $A$. anguilla) have reported turbine mortality rates between $9 \%$ and $60 \%$ at hydroelectric dams, with larger individuals being more susceptible to turbine injury and mortality (Winter et al., 2006; Bruijs et al., 2009; Calles et al., 2010; Pedersen et al., 2012). Radio-tagged American Eels in the Shenandoah River were of similar size to European Eels in the aforementioned studies, and turbine mortality during regular operation in this study was within the range reported in other published studies. 
During a previous study at the Luray Dam, Euston et al. (1998) netted American Eels from the discharge of one of the three turbines at the dam to determine immediate and latent mortality. The immediate turbine mortality rate from that study was $1 \%$ with a latent mortality rate of $8.9 \%$. My study demonstrated that $41 \%$ of American Eels migrating through turbines at the Luray Dam experienced immediate turbine mortality, with no estimate of delayed mortality. The turbine mortality rates of Euston et al. (1988) are less than those observed in this study and less than turbine mortality study results from the mainstem Potomac River dams or other hydroelectric dams on other rivers (Normandeau Associates, 2001; Winter et al., 2006; Bruijs et al., 2009; Calles et al., 2010; Pedersen et al., 2012). One possible explanation for the difference in measured mortality rates between studies at the Luray Dam may be because the 1998 study only evaluated the discharge from the smallest capacity unit of the three units at the dam. The unit evaluated in the previous study may have had a lower mortality rate than the other two units operating at the dam. This study did not discriminate between units, but was a combined measure of turbine mortality from all units.

For all dams, turbine mortality estimates are minimum estimates because only immediate mortality was assessed at the dam tailrace. Eels can be injured or experience latent mortality when passing through turbines (Hadderingh and Bakker, 1998). Winter et al. (2006) estimated latent mortality to be an additional $7 \%$ to $17 \%$ for European Eels passing through turbines. Several tagged American Eels did not complete migration out of the Shenandoah River prior to the study completion or before their radio tags ceased working. Possible explanations for the ending of migration prior to leaving the study site include latent mortality, intentional partial migrations, or tag loss. Partial migrations occurring over more than one study year were 
rarely observed in the Shenandoah River. The battery life span of tags used in the second and third years of the study would assure that most migrations that spanned two study years would be detected, therefore partial migrations were likely not the reason for individuals not making complete migrations out of the Shenandoah River. Two American Eels were recaptured that had tagging scars, but did not have tags in their abdominal cavity, so it was assumed that tag loss did occur at some level in the study. Assuming some tag loss did occur between dams during migration, I could not discriminate between tag loss and latent mortality to determine latent mortality rates in this study.

Although individual dam mortality rates were relatively low when including data from the nighttime shutdown periods (ranging from 3\% to 14\%), American Eels have to migrate downstream past up to five hydroelectric dams on the Shenandoah River before they can escape downstream to the Potomac River and Chesapeake Bay. Cumulative mortality can substantially reduce overall American Eels escapement from the Shenandoah River. Cumulative mortality during regular dam operation (not including shutdowns) was $63 \%$ for individuals that would pass all five dams. Some rivers have much more than five hydroelectric dams, resulting in high cumulative mortality rates for the largest and most fecund individuals leaving the upper reaches of the river. For example, the Kennebec River in Maine has 22 hydroelectric dams in the basin. Modeling results assuming a very low mortality rate at each dam (10\%), still results in $60 \%$ cumulative mortality for female American Eels leaving the river (McCleave, 2001). Although turbine mortality of silver American Eels can be reduced at individual dams, it should be managed between projects on a river-wide scale to protect eels leaving the river to spawn. 
In the Shenandoah River, turbine shutdowns were successful in reducing silver American Eel mortality. The daily timing for the turbine shutdown period protected the majority of downstream migrating American Eels. The time period from 18:00 to 06:00 hours encompassed $81 \%$ of the migration events. A shift in the shutdown period to one hour earlier would have increased the protection to include $87 \%$ of the downstream migrants. It did not appear that the implementation of turbine shutdowns affected the timing of downstream migrations past dams as indicated by similar proportions of individuals migrating at night (18:00-06:00) during shutdown and non-shutdown periods ( $81 \%$ and $87 \%$ respectively).

The seasonal timing for implementing turbine shutdowns was less successful in protecting downstream migrants, with only $64 \%$ of the migrants passing downstream during the time of year (15 September to 15 December) when nighttime turbine shutdowns were conducted during the study. The timing for implementing the nighttime shutdown period on the Shenandoah River was established based on the Euston et al. (1998) study, as well as assumed regional timing of downstream migrations (i.e. Facey and Van Den Avyle, 1987). However, the seasonal timing of downstream migration was highly variable among the three years of this study. During the first year (Sep 2007-Aug 2008) very few (9\%) radio-tagged American Eels migrated downstream during the dates when turbine shutdowns were implemented. The majority of passage during the first year was during late December and early spring. In the following year (Sep 2008-Aug 2009), 65\% of American Eels migrated downstream during the 90 days of turbine shutdowns, with another peak in passage in March and April. During the final year (Sep 2009-Aug 2010), downstream migration occurred almost exclusively 
in November and nearly all of the migrants during that study year passed downstream during the dates of turbine shutdowns.

Due to the high variability between the three years of the study, it appears that American Eels would benefit from a longer period of nighttime shutdowns, including time in the spring. A total of $24 \%$ of migration events in this study occurred during the months of February through April. If an additional 90-day shutdown period was implemented during these months, $88 \%$ of the total migration events would have been encompassed in the entire shutdown period. Increasing the number of days for the shutdown period would benefit American Eels, but would also likely impact revenue generated by the power company.

Shutdowns have not been frequently implemented to protect silver American Eels. Several hydroelectric dams in Maine have been required to implement seasonal nighttime shutdowns to protect silver American Eels, but little information has been collected to determine the success of the shutdown periods to protect downstream migrants (G. Wipplehauser, Maine Dept. of Marine Resources, pers. comm.). Modeling results from simulated shutdowns in Maine rivers based on protecting the $25^{\text {th }}$ to $75^{\text {th }}$ percentiles of the run as well as on days of rainfall could reduce the overall mortality from $10.7 \%$ to $3.9 \%$ (Haro et al., 2003). In a study on Shortfinned and Longfinned Eels (A. australis and A. dieffenbachii) in New Zealand, turbine shutdown was attempted in conjunction with opening spill gates during high flow events. However, few females were collected through the sluice, so it was determined that turbine shutdowns may not be effective for protecting downstream migrants at that location (Boubée et al., 2003). 
Shutdowns based on time of day and calendar date could be beneficial, but the timing for implementation could further be refined by monitoring environmental variables associated with migration events. Shutdowns based on environmental variables, however, may be logistically difficult to implement for dam operators. Studies on silver eel migrations in North America as well as Europe found that downstream migrations usually occur with increased river discharge, when water temperatures are declining and near the time of the new moon (Durif et al., 2003; Haro, 2003; Winter et al., 2006). In this study, I also evaluated the correlation of migration events and environmental variables, such as river discharge, temperature, and lunar phase (Chapter 3). As with other studies, silver American Eels in the Shenandoah River usually migrated downstream during times of high river discharge and during an optimal temperature range $\left(5-12^{\circ} \mathrm{C}\right.$, Chapter 3). Shutdown periods on the Shenandoah River could be shortened in the fall and spring months to a period at night when river discharge is high and water temperatures are within an optimal range. Using a combination of seasonal nighttime shutdowns linked to environmental variables may allow for additional protection during other times of the year (besides fall) without increasing the total number of days (i.e. $90 \mathrm{~d}$ in the Shenandoah River) where shutdowns would be implemented.

The implementation of seasonal nighttime turbine shutdowns reduced turbine mortality on downstream migrating silver American Eels in the Shenandoah River. The current time of day of the shutdown period protected most migrants, but shifting the shutdown period to one hour earlier (17:00 to 05:00) could have increased protection. The seasonal timing of the shutdown period encompassed about two-thirds of the migration events. Adding additional nighttime shutdown days in the spring may increase survival. It may be possible to link 
nighttime shutdown events with environmental variables to refine the times during the fall and spring when shutdowns should be implemented. Additional measures, such as bypass facilities, preferential turbine passage, or trap and transport, could potentially be implemented in the Shenandoah River; however any of these methods would require either the expense of installing and maintaining bypass facilities and/or screening or the operation of a trap and transport operation. The seasonal nighttime shutdown periods require no capital investment by the dam owner, but do result in a loss of revenue from loss of power generation. Turbine shutdowns increase survival of downstream migrating American Eels and should be considered as one of a suite of methods that can be implemented at run-of-the-river hydroelectric dams to reduce turbine mortality and promote timely downstream migration of adult American Eels. 


\section{References:}

Acou, A., Laffaille, P., Legault, A., and Feunteun, E. 2008. Migration pattern of silver eels (Anguilla anguilla, L.) in an obstructed river system. Ecology of Freshwater Fish, 17: 432442.

Atlantic States Marine Fisheries Commission (ASMFC). 2012. American Eel benchmark stock assessment. Stock Assessment Report No. 12-01 of the Atlantic States Marine Fisheries Commission. Arlington, Virginia, 338 pp.

Beeman, J. W., Grant, C., and Haner, P. V. 2004. Comparison of three underwater antennas for use in radio telemetry. North American Journal of Fisheries Management, 24: 275-281.

Boubée, J., Chisnall, B., Watene, E., and Williams, E. 2003. Enhancement and management of eel fisheries affected by hydroelectric dams in New Zealand. In Biology, management, and protection of catadromous eels, pp. 191-205. Ed. by D. A. Dixon, American Fisheries Society, Symposium 33, Bethesda, Maryland, 388 pp.

Boubée, J. A. T., and Williams, E. K. 2006. Downstream passage of silver eels at a small hydroelectric facility. Fisheries Management and Ecology, 13: 165-176.

Brown, L., Haro, A. and Castro-Santos, T. 2009. Three-dimensional movement of silver-phase American Eels in the forebay of a small hydroelectric facility. In Eels at the edge: science, status, and conservation concerns, pp. 277-291. Ed. J. M. Casselman and D. K. Cairns, American Fisheries Society, Symposium 58, Bethesda, Maryland, 449 pp.

Bruijs, M. C. M., Hadderingh, R. H., Schwevers, U., Adam, B., Dumont, U., and Winter, H. V. 2009. Managing human impact on downstream migrating European Eel in the River Meuse. In Eels at the edge: science, status, and conservation concerns, pp. 381-390. Ed. 
J. M. Casselman and D. K. Cairns, American Fisheries Society, Symposium 58, Bethesda, Maryland, $449 \mathrm{pp}$.

Buysse, D., Mouton, A. M., Stevens, M., Van Den Neucker, T., and Coeck, J. 2014. Mortality of European eel after downstream migration through two types of pumping stations. Fisheries Management and Ecology, $21: 13-21$.

Calles, O., Olsson, I. C., Comoglio, C., Kemp, P. S., Blunden, L., Schmitz, M., and Greenberg, L. A. 2010. Size-dependent mortality of migratory silver eels at a hydropower plant, and implications for escapement to the sea. Freshwater Biology, 55: 2167-2180.

Carr, J. W., and Whoriskey, F. G. 2008. Migration of silver American Eels past a hydroelectric dam and through a coastal zone. Fisheries Management and Ecology, 15: 393-400.

Durif, C., Elie, P., Gosset, C., Rives, J., and Travade, F. 2003. Behavioral study of downstream migrating eels by radio-telemetry at a small hydroelectric power plant. In Biology, management, and protection of catadromous eels, pp. 343-356. Ed. by D. A. Dixon, American Fisheries Society, Symposium 33, Bethesda, Maryland, 388 pp.

EPRI (Electric Power Research Institute). 1999. American Eel (Anguilla rostrata) Scoping Study: a literature review of life history, stock status, population dynamics, and hydroelectric impacts. EPRI, TR-111873. Palo Alto, California, 90 pp.

Euston, E. T., Royer, D. E., and Simons, C. L. 1998. American Eels and hydro plants: clues to Eel passage. Hydro Review, 17: 94-103.

Facey, D. E., and Van Den Avyle, M. J. 1987. Species profiles: life histories and environmental requirements of coastal fishes and invertebrates (North Atlantic)-American Eel. USFWS Biological Report 82 (11.74). U.S. Army Corps of Engineers, TR EL-82-4. 28 pp. 
Feunteun, E., Acou, A., Laffaille, P., and Legault, A. 2000. European Eel (Anguilla anguilla): prediction of spawner escapement from continental population parameters. Canadian Journal of Fisheries and Aquatic Sciences, 57: 1627-1635.

Gosset, C., Travade, F., Durif, C., Rives, J., and Elie, P. 2005. Tests of two types of bypass for downstream migration of eels at a small hydroelectric power plant. River Research and Applications, 21: 1095-1105.

Hadderingh, R. H., and Bakker, H. D. 1998. Fish mortality due to passage through hydroelectric power stations on the Meuse and Vecht rivers. In Fish migration and fish bypasses, pp. 315-328. Ed. M. Jungwirth, S. Schmutz, and S. Weiss, Fishing News Books, Oxford, UK, $448 \mathrm{pp}$.

Haro, A. 2003. Downstream migration of silver-phase anquillid eels. In Eel biology, pp. 215-222. Ed. K. Aida, K. Tsukamoto, and K. Yamauchi, Springer-Verlag, New York, 497 pp. Haro, A., and Castro-Santos, T. 2000. Behavior and passage of silver-phase American Eels, Anguilla rostrata (LeSueur), at a small hydroelectric facility, Dana 12: 33-42.

Haro, A., Castro-Santos, T., Whalen, K., Wippelhauser, G., and McLaughlin, L. 2003. Simulated effects of hydroelectric project regulation on mortality of American Eels. In Biology, management, and protection of catadromous eels, pp. 357-365. Ed. by D. A. Dixon, American Fisheries Society, Symposium 33, Bethesda, Maryland, 388 pp.

Jansen, H. A., Winter, H. V., Bruijs, M. C. M., and Polman, H. J. G. 2007. Just go with the flow? Route selection and mortality during downstream migration of silver eels in relation to river discharge. ICES Journal of Marine Science, 64: 1437-1443. 
Klein Breteler, J., Vriese, T., Borcherding, J., Breukelaar, A., Jörgensen, L., Staas, S., de Laak, G., and Ingendahl, D. 2007. Assessment of population size and migration routes of silver eels in the River Rhine based on a 2-year combined mark-recapture and telemetry study. ICES Journal of Marine Science, 64: 1450-1456.

McCarthy, T. K., Frankiewicz, P., Cullen, P., Blaszkowski, M., O’Connor, W., and Doherty, D. 2008. Long-term effects of hydropower installations and associated river regulation on River Shannon eel populations: mitigation and management. Hydrobiologia, 609: 109124.

McCleave, J. D. 2001. Simulation of the impact of dams and fishing weirs on reproductive potential of silver-phase American Eels in the Kennebec River basin, Maine. North American Journal of Fisheries Management, 21: 592-605.

McGrath, K. J., J. Bernier, S. Ault, J.-D. Dutil, and K. Reid. 2003. Differentiating downstream migrating American Eels Anguilla rostrata from resident eels in the St. Lawrence River. In Biology, management, and protection of catadromous eels, pp. 315-327. Ed. by D. A. Dixon, American Fisheries Society, Symposium 33, Bethesda, Maryland, 388 pp.

Normandeau Associates, Inc. 2001. Review and reanalysis of entrainment studies at Dam No. 4 hydro station, Potomac River, MD/WV.

Pedersen, M. I., Jepsen, N., Aarestrup, K., Koed, A., Pedersen, S., and Økland, F. 2012. Loss of European silver eels passing a hydropower station. Journal of Applied Ichthyology, 28: 189-193. 
Piper, A. T., R. M. Wright, A. M. Walker, P. S. Kemp. 2013. Escapement, route choice, barrier passage and entrainment of seaward migrating European eel, Anguilla anguilla, within a highly regulated lowland river. Ecological Engineering, 57: 88-96.

Ross, M. J., and Kleiner, C. F. 1982. Shielded-needle technique for surgically implanting radiofrequency transmitters in fish. Progressive Fish Culturist, 44: 41-43.

Wantene, E. M., and Boubée, J. A. T. 2005. Selective opening of hydroelectric dam spillway gates for downstream migrant eels in New Zealand. Fisheries Management and Ecology, 12: $69-75$.

Winter, H. V., Jansen, H. M., and Bruijs, M. C. M. 2006. Assessing the impact of hydropower and fisheries on downstream migrating silver eels, Anguilla anguilla, by telemetry in the River Meuse. Ecology of Freshwater Fish, 15: 221-228. 
Table 1. Percentage of time spent between first detection and passage at each hydroelectric dam on the Shenandoah River (number of individuals in parentheses).

\begin{tabular}{lcccccc}
\hline & & & & & & All Dams \\
Delay & Shenandoah & Newport & Luray & Warren & Millville & Combined \\
Duration & $(\%)$ & $(\%)$ & (\%) & (\%) & (\%) & (\%) \\
\hline$<1 \mathrm{~h}$ & $71(5)$ & $48(10)$ & $25(12)$ & $75(47)$ & $69(40)$ & $58(114)$ \\
$1-24 \mathrm{~h}$ & $14(1)$ & $14(3)$ & $48(23)$ & $14(9)$ & $17(10)$ & $23(46)$ \\
$1-10 \mathrm{~d}$ & $0(0)$ & $24(5)$ & $13(6)$ & $3(2)$ & $10(6)$ & $10(19)$ \\
$>10 \mathrm{~d}$ & $14(1)$ & $14(3)$ & $15(7)$ & $8(9)$ & $3(2)$ & $9(18)$ \\
Median & & & & & & \\
Delay (h) & 0.28 & 1.22 & 12.2 & 0.38 & 0.57 & 0.77 \\
\hline
\end{tabular}


Table 2. Migratory delay at different river discharge levels for American Eels migrating past five hydroelectric dams on the Shenandoah River from September 2007 through August 2010.

\begin{tabular}{|c|c|c|c|c|}
\hline & $<2$ times & $2-3$ times & $3-5$ times & $>5$ times \\
\hline & median & median & median & median \\
\hline & Discharge & Discharge & Discharge & Discharge \\
\hline Delay Duration & (\%) & (\%) & (\%) & (\%) \\
\hline$<1 \mathrm{~h}$ & 33 & 72 & 77 & 70 \\
\hline $1-24 \mathrm{~h}$ & 28 & 14 & 16 & 28 \\
\hline $1-10 d$ & 19 & 10 & 5 & 0 \\
\hline$>10 d$ & 20 & 3 & 2 & 2 \\
\hline Median Delay & $15 \mathrm{~h}$ & $0.70 \mathrm{~h}$ & $0.35 \mathrm{~h}$ & $0.33 \mathrm{~h}$ \\
\hline
\end{tabular}


Table 3. Turbine mortality rates of American Eels that passed four hydroelectric dams on the Shenandoah River from September 2007 through August 2010.

\begin{tabular}{|c|c|c|c|c|}
\hline \multirow[b]{3}{*}{ Dam } & \multicolumn{3}{|c|}{ No. Suspected } & \multirow[b]{2}{*}{$95 \%$ Confidence } \\
\hline & No. Turbine & Turbine & Turbine & \\
\hline & Passage Events & Mortality & Mortality (\%) & Limits (\%) \\
\hline Newport & 6 & 2 & 33 & $7-71$ \\
\hline Luray & 27 & 11 & 41 & $24-59$ \\
\hline Warren & 19 & 3 & 16 & $5-36$ \\
\hline Millville & 26 & 5 & 19 & $8-36$ \\
\hline
\end{tabular}


Table 4. Mortality of American Eels at five hydroelectric dams on the Shenandoah River from September 2007 through August 2010.

\begin{tabular}{lcccc}
\hline & Total No. Eel & No. Suspected & Overall Project & 95\% Confidence \\
Dam & Passed Project & Turbine Mortality & Mortality (\%) & Limits (\%) \\
\hline Shenandoah & 33 & 1 & 3 & $0-12$ \\
Newport & 56 & 8 & 14 & $7-24$ \\
Luray & 83 & 11 & 13 & $8-21$ \\
Warren & 63 & 3 & 5 & $2-11$ \\
Millville & 58 & 5 & 9 & $4-17$ \\
Cumulative Mortality & & & 51 & \\
\hline
\end{tabular}


Table 5. Passage method and turbine mortality for American Eel migrating downstream during nighttime turbine shutdowns (15 September to 15 December, 18:00 to 06:00 hours) compared to regular operation at five dams on the Shenandoah River from September 2007 through August 2010. The 95\% confidence limit is noted in parentheses.

\section{Turbine Shutdowns}

Overall

Turbine Project

Total No. passage* Mortality

Passed

Dam

Shenandoah

Newport

Luray

Warren

Millville

Cumulative Mortality
17

35

31

29

27

4

Shutdown

0
(\%)

(\%)
$7(2-41)$

\section{Regular Operation}

\section{Overall}

\section{Turbine Project}

Total No. passage* Mortality

Passed

(\%)

(\%)

$6(0-24)$

21

$43 \quad 38(20-59)$

52

48

17 (9-29)

$0(0-7)$

34

56

$9(2-21)$

31

81

$16(6-31)$

Rest of Year 63 (33-88)

*Percent Turbine passage calculated from data where passage method was known, passage method for Shenandoah Dam was not available. 
Figure 1. Potomac and Shenandoah river watersheds and location of five hydroelectric dams monitored with stationary radio telemetry for silver American Eel passage. All collection and tagging occurred upstream of the Luray Dam.

Figure 2. Generalized diagram of telemetry monitoring antenna array at a Shenandoah River Dam. The antenna indicated by a star is an aerial 6-element Yagi with a detection distance of about $1 \mathrm{~km}$ (the entire area of the diagram). Antennas indicated by triangles are underwater antennas with a detection distance identified by the shaded area (range from 5 to $15 \mathrm{~m}$ ).

Figure 3. Percent of American Eel passage events by month during the three study years on the five hydroelectric dams on the Shenandoah River. Passage was monitored continuously from September 2007 through August 2010. Annual study periods began on 1 September and continued through 31 August of the following year.

Figure 4. Percent of American Eel passage events by hour of day during the season of turbine shutdowns (15 September to 15 December) and during the rest of the year at five hydroelectric dams on the Shenandoah River from 2007-2010. 


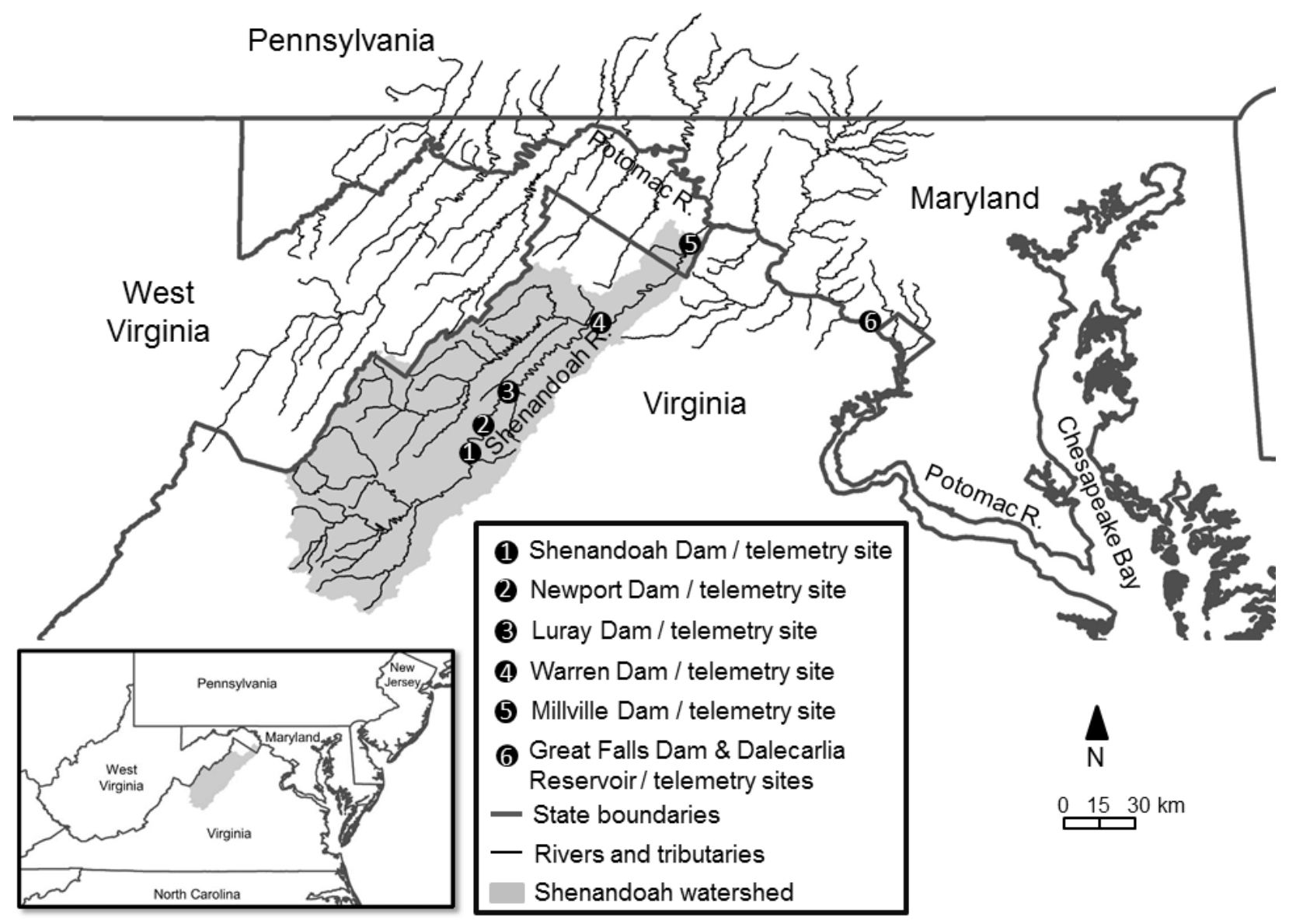




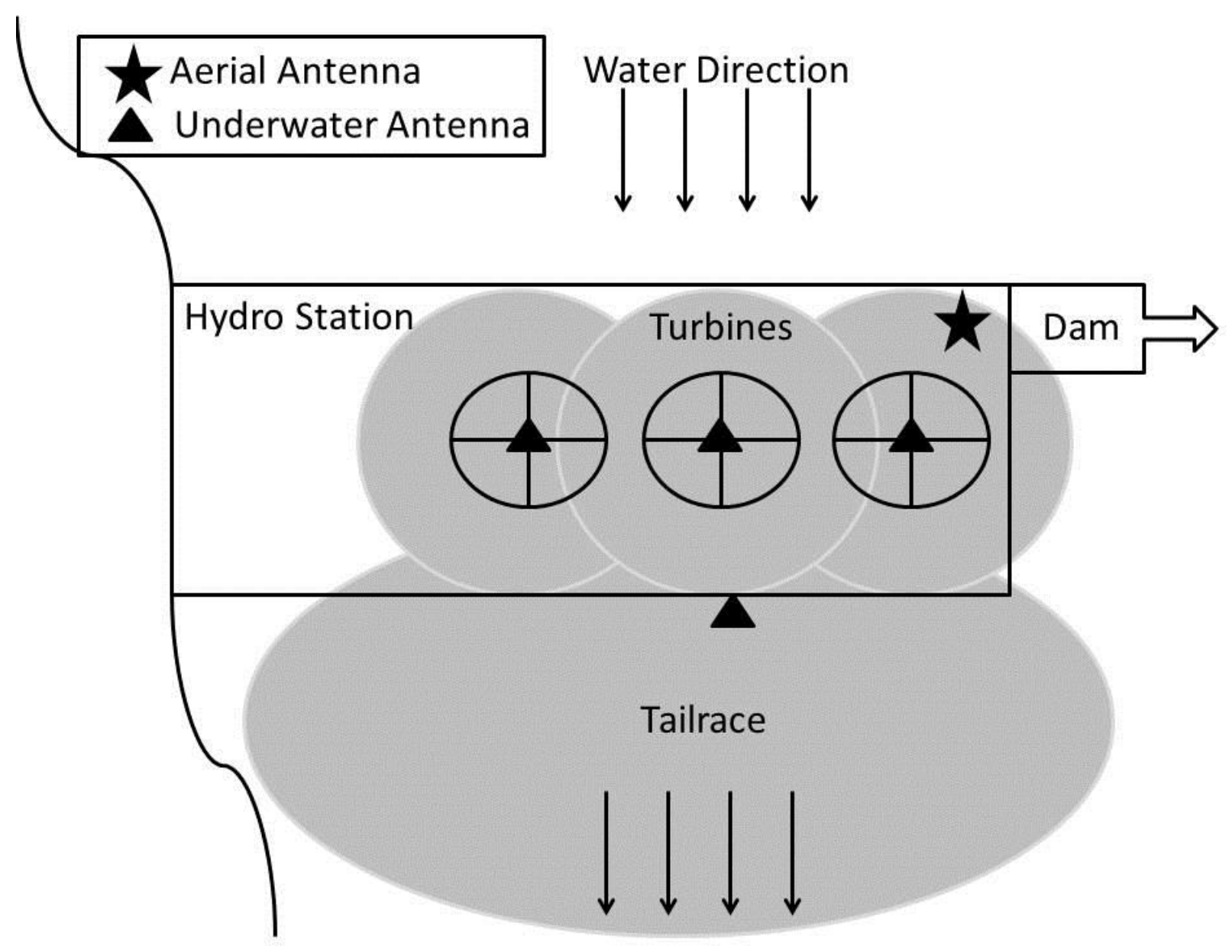




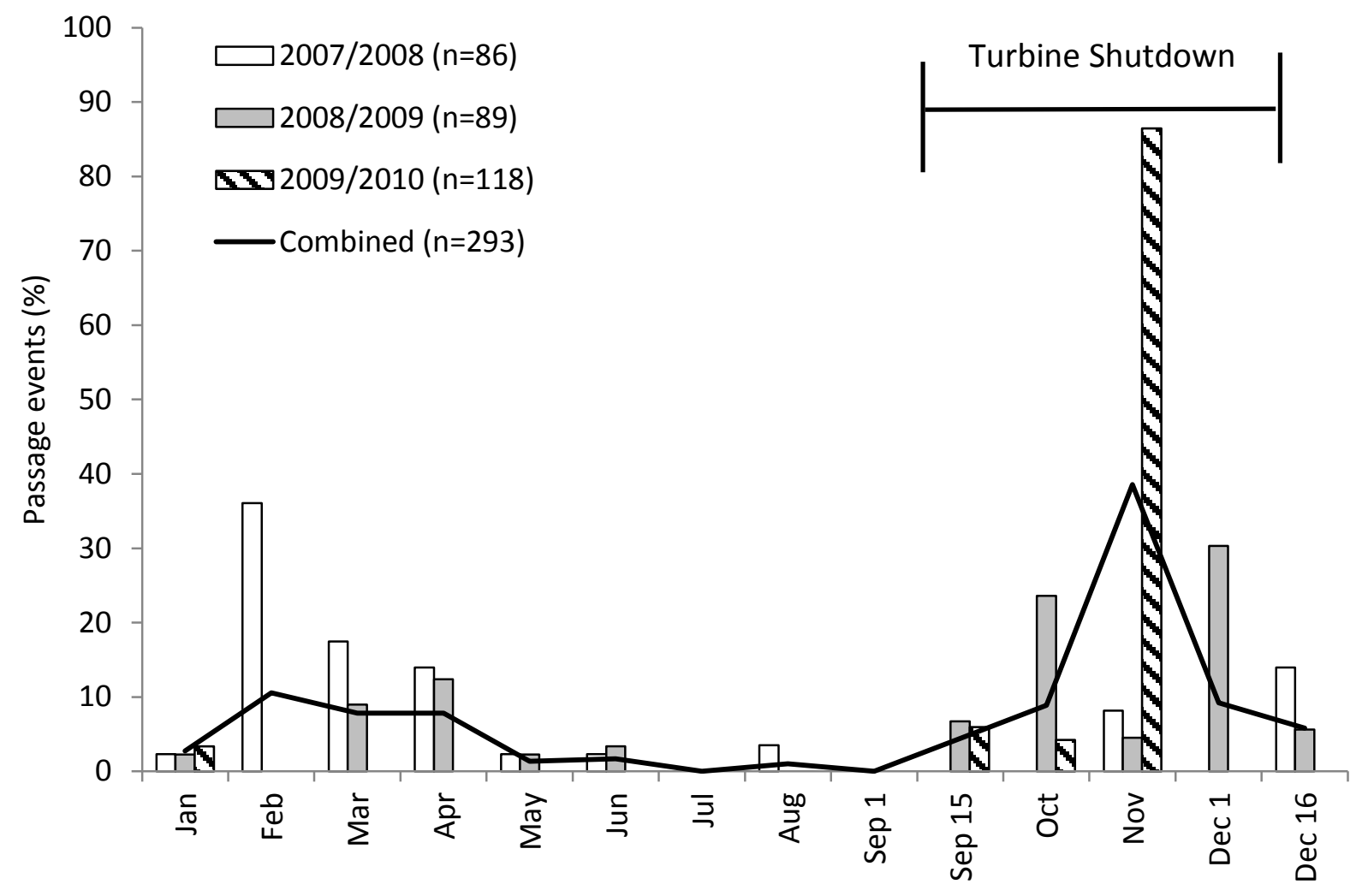




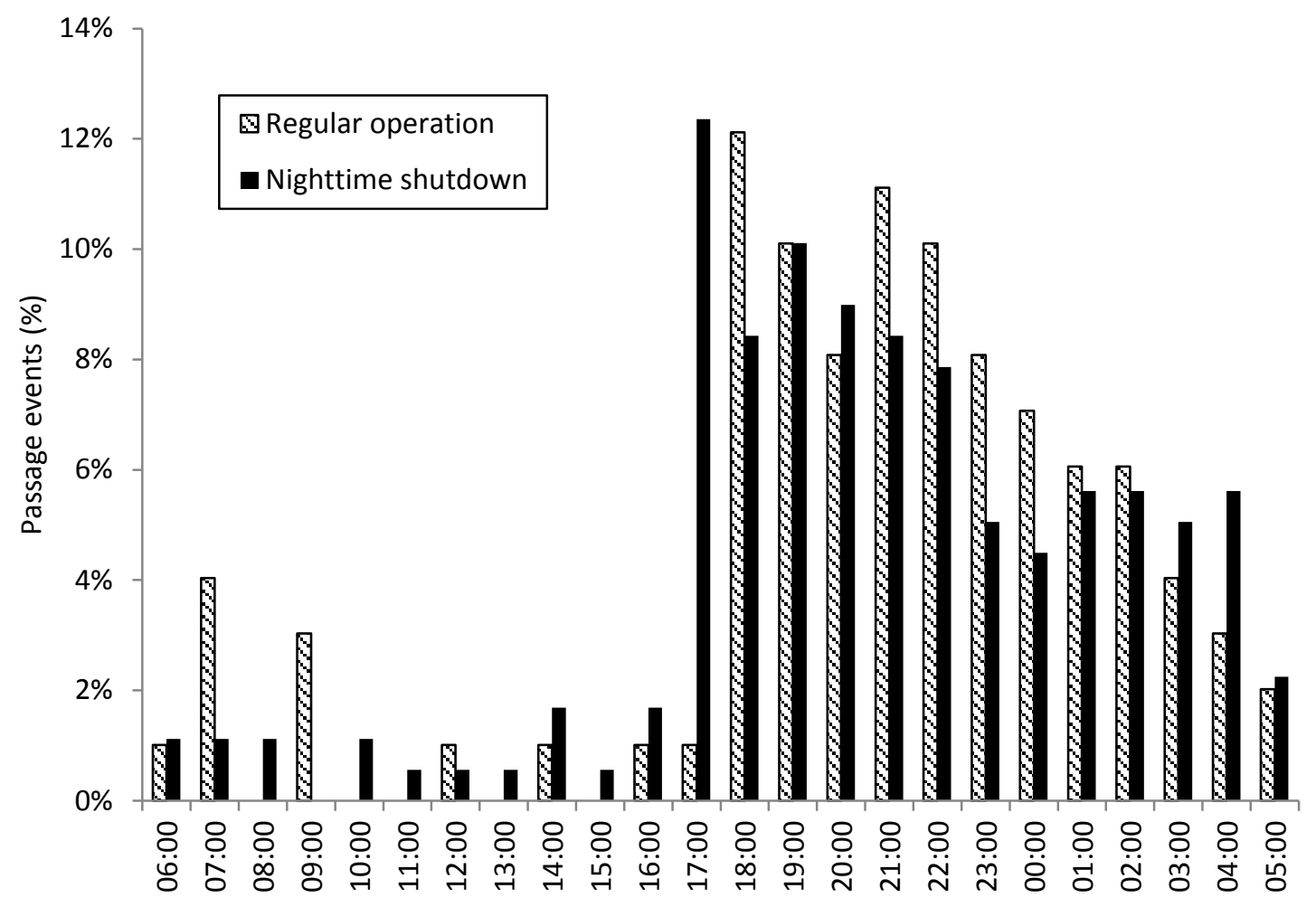


Chapter 5 - Management actions for protecting downstream migrating American Eels (Anguilla rostrata)

The hydroelectric dam operators on the Shenandoah River have periodically ceased turbine operation to protect downstream migrating adult American Eels (Anguilla rostrata). The current schedule for shutting down turbine operation is based on time of year (September 15 December 15) and time of day (18:00 - 06:00) when American Eels are assumed to be migrating downstream based on past research studies in the watershed (i.e. Euston et al. 1998). The intent of this study was to evaluate the extent to which the current turbine shutdown period protected downstream migrating American Eels. The results indicate that turbine shutdowns did reduce mortality on downstream migrants, but the current seasonal implementation of the management measure did not encompass all of the downstream migration period.

During the three-year radio telemetry study, American Eels migrated downstream over a longer annual time period than previously described. Telemetered American Eels completed downstream migration events past dams during every month of the year except for July. Although two-thirds of the migration events occurred during the current shutdown period, $25 \%$ of migration events occurred during spring months. Spring migration has been rarely documented in the literature for European Eels (A. anguilla) and not at all for American Eels. Spring migration occurred on the Shenandoah River during two of the three years of study, and peak migrations in the first study year were during late winter and early spring. Although the time of year for downstream migrations during this study was much broader than previously documented, time of day for migration used for the turbine shutdown period (18:00-06:00 
hours), was similar to the daily timing of the majority of migration events during this study ( $87 \%$ from 17:00 to 05:00 hours).

Downstream migration events by American Eel on the Shenandoah River were also associated with environmental variables. American Eels migrated downstream during higher levels of river discharge and during times of increasing discharge. Downstream migration was also more likely to occur when water temperatures were between 6 and $14^{\circ} \mathrm{C}$. Based on this study, lunar illumination, time of year, and the dam location were not significant variables associated with downstream migrations. When attempting to describe the timing of downstream migration events at Shenandoah River dams, a model using river discharge, change in river discharge, and water temperatures was successful in describing when the majority of dam passage events occurred during the study period.

When American Eels migrated downstream, they generally passed several dams in a relatively short period of time and with minimal migratory delay. The mean time to migrate the $195 \mathrm{~km}$ past all five hydroelectric dams on the Shenandoah River was 38 days and migration events were typically completed within one month of initiation. Migratory delays were generally less than one day at each dam, and over half of the passage events occurred in less than one hour after an eel approached a dam. The speed of migrating American Eels in the Shenandoah River, where migrants encountered several dams, was not significantly different than those in the undammed section of the Potomac River, suggesting further that the hydroelectric dams on the Shenandoah River were not causing excessive migratory delay. American Eels passed dams either by traveling through hydroelectric turbines or spilling over the top of the dam, which ranged in height from 4.5 to $8.7 \mathrm{~m}$. During periods of generation 
while turbines were operating, $65 \%$ of the American Eels migrating downstream passed through turbines. Turbine passage by American Eels was reduced to $5 \%$ during turbine shutdown periods. A total of $29 \%$ of the American Eels in the study suffered immediate turbine mortality, and nearly half of the eels that passed through turbines at least one time on the river were killed. Mortality rates for the individual dams ranged from $14 \%$ to $67 \%$ during turbine operation, which was reduced to a range of $0 \%$ to $6 \%$ during turbine shutdown periods. During turbine operation, American Eels leaving the upper watershed having to pass all five dams to escape the river suffered a cumulative mortality rate of $63 \%$. Turbine shutdowns, during the time period they were implemented, reduced the cumulative mortality rate of American Eels leaving the upper watershed to $7 \%$.

The current American Eel population is considered depleted (ASMFC 2012) and migrants from the Shenandoah River and other freshwater tributaries could likely contribute to population growth. American Eels migrating downstream in the Shenandoah River were large female eels, ranging from 72 to $102 \mathrm{~cm}$ total length. Fecundity of American Eels is related to length (Barbin and McCleave 1997), and these relatively large eels could contribute proportionally more to the coast-wide spawning population compared to their smaller downstream counterparts. Turbine mortality for five hydroelectric dams on the Shenandoah River had cumulative impacts on silver American Eels migrating from the upper watershed. Protecting the downstream migrants in the Shenandoah River and other upstream areas of freshwater rivers could increase escapement of highly fecund female eels and potentially benefit restoration of the American Eel population. 
The implementation of turbine shutdown periods has reduced turbine related mortality for downstream migrating American Eels in the Shenandoah River. The current seasonal implementation of nighttime shutdowns was in effect during half of the downstream migration events, but a large number of days when turbine shutdowns were implemented did not have American Eel downstream passage events. Conversely, there were periods outside the September 15 to December 15 time period where downstream passage events occurred and turbines were running. It may be possible to increase protection for downstream migrants by using a combination of river discharge and water temperature, rather than calendar dates, to determine when nighttime turbine shutdowns should occur. Use of environmental variables may allow for increased protection of migrating American Eels without increasing the current annual number of days for nighttime turbine shutdowns.

The next step in protection for American Eels in the Shenandoah River would be to develop a predictive model based on environmental variables to determine when turbine shutdowns would offer the highest level of protection as well as consideration of the impacts on hydroelectric generation. This study has focused on protection for American Eels but has not considered the potential financial impacts to the power company if shutdowns are based on environmental variables. The impacts of lost generation during high discharge events or during different seasons of the year could be more complex than implementing 90 days of turbine shutdown during different times of year. In addition, consideration should be given to the actual field level implementation of an environmental variable based turbine shutdown period. There may be difficulty in forecasting the combinations of river discharge and water temperature to provide advanced notice for shutdowns to be implemented. In the case of the 
Shenandoah River, the hydroelectric stations do not have 24-hour supervision. Logistical constraints for implementing manual turbine shutdowns and restarts should be considered when determining the best method to protect downstream migrating American Eels. A coordinated effort should be implemented with the hydroelectric company to consider methods to increase protection of downstream migrating American Eels while meeting the operational needs of the hydroelectric company. If the turbine shutdown period is adjusted to incorporate environmental variables into the implementation, additional field studies to validate the success of the modified shutdown periods should be conducted.

In addition, further studies should be conducted to evaluate downstream migration of the American Eel in the Potomac River. This study demonstrated that the Washington Aqueduct (through detections in Dalecarlia Reservoir) did entrain at least three radio-tagged American Eels. Providing for better telemetry coverage at the Dalecarlia Reservoir and the Little Falls Dam as well as adding monitoring equipment at the Washington Aqueduct Dam at Great Falls would improve our understanding of survival through the middle region of the Potomac River. In addition, a telemetry station downstream of Great Falls could provide information on survival through this natural feature that may further impact escapement of mature American Eels from the upper Potomac River. 


\section{References:}

Atlantic States Marine Fisheries Commission (ASMFC). 2012. American Eel benchmark stock assessment. Stock Assessment Report No. 12-01 of the Atlantic States Marine Fisheries Commission. Arlington, Virginia, 338 p.

Barbin, G. P., and J. D. McCleave. 1997. Fecundity of the American Eel Anguilla rostrata at $45^{\circ} \mathrm{N}$ in Maine, U.S.A. Journal of Fish Biology 51:840-847.

Euston, E. T., Royer, D. E., and Simons, C. L. 1998. American Eels and hydro plants: clues to eel passage. Hydro Review 17: 94-103. 


\section{Curriculum Vitae (CV)}

\section{SHEILA M. EYLER}

Work: USFWS - Mid-Atlantic Fish and Wildlife Coordination Office 177 Admiral Cochrane Drive, Annapolis, MD 21401

(410) 573-4554

Sheila_Eyler@fws.gov

EDUCATION:

Bachelor of Arts, 1997, Gustavus Adolphus College, St. Peter, MN Major: Biology GPA: 3.475 Cum Laude

Masters of Science, 2000, University of Maryland - Eastern Shore, Princess Anne, MD Marine and Estuarine Environmental Science Program, Fisheries Area of Specialization Maryland Fish and Wildlife Cooperative Research Unit, Dr. F. J. Margraf, Advisor GPA: 3.58

Doctor of Philosophy,2014, West Virginia University, Morgantown, WV Division of Forestry and Natural Resources, Wildlife and Fisheries Resources West Virginia Fish and Wildlife Cooperative Research Unit, S. A. Welsh, Advisor

\section{EMPLOYMENT:}

\section{U.S. Fish and Wildlife Service}

Project Leader - Mid-Atlantic Fish and Wildlife Coordination Office June 2014-present

Acting Project Leader - Susquehanna River Coordinator

February 2013 to June 2014

Fishery Biologist - Maryland Fishery Resources Office

April 1999 - June 2014

\section{WORK EXPERIENCE:}

- Represent USFWS and serve as Chair to the Susquehanna River Anadromous Fish Restoration Cooperative Technical Committee and Secretary to the Policy Committee

- Represent USFWS and serve as representative and Secretary to the Delaware River Basin Fish and Wildlife Management Cooperative

- Team member of the USFWS FERC relicensing team for Susquehanna River Hydroelectric Projects

- USFWS representative to the Susquehanna River Basin Commission and Delaware River Basin Commission

- Represent the U.S. Fish and Wildlife Service on several committees and workgroups in the Atlantic States Marine Fisheries Commission for the management of interjurisdictional fisheries along the Atlantic Coast 
- Current Chair of the Technical Committee (fall 2013 -2015) and represent the Technical Committee at the quarterly Management Board meetings

- Member of the Tagging Workgroup and Plan Review Team for Horseshoe Crab

- Member of the Tagging Workgroup for Atlantic Sturgeon

- Coordinated and managed Cooperative Tagging Programs for Horseshoe Crabs and Sturgeon

- Co-Developer and Co-Instructor for a course in Data Management offered annually by the National Conservation Training Center

\section{PEER REVIEWED PUBLICATIONS:}

Sweka, J.A., S. Eyler, and M.J. Millard. 2014. An egg-per-recruit model to evaluate the effects of upstream transport and downstream passage mortality of American Eel in the Susquehanna River. North American Journal of Fisheries Management 34:764-773.

Hitt, N.P., S. Eyler, and J.E.B. Wofford. 2012. Dam removal increases American eel abundance in distant headwater streams. Transactions of the American Fisheries Society 141:1171-1179.

Smith, D.R., M.J. Millard, and S. Eyler, 2006. Abundance of adult horseshoe crabs in Delaware Bay estimated from a large-scale mark-recapture study. Fishery Bulletin 104:456-464.

Eyler, S. M., L. E. Vogel, and F. J. Margraf. 2002. Effectiveness of a fish passage facility for anadromous river herring. Proceedings to the 2002 Annual Conference of Southeastern Association of Fish and Wildlife Agencies 56:55-64.

Welsh, S. A., S. M. Eyler, M. F. Mangold, and A. J. Spells. 2002. Capture locations and growth rates of Atlantic Sturgeon in the Chesapeake Bay. Pages 183-194 in W. VanWinkle, P. J. Anders, D. H. Secor, and D. A. Dixon, editors. Biology, management, and protection of North American sturgeon. American Fisheries Society Symposium 28, Bethesda Maryland.

Welsh, S. A., M. F. Mangold, S. M. Eyler. 2002. Movements of shortnose sturgeon in the Chesapeake Bay, Maryland. Estuaries 25(1):101-104.

Welsh, S. A., M. F. Mangold, S. M. Eyler. 2001. Movement of shortnose sturgeon in the Upper Chesapeake Bay, Maryland. Proceedings to the 2002 Annual Conference of Southeastern Association of Fish and Wildlife Agencies 55:298-303.

Eyler, S. M. 2000. Potential impacts of a fishway and predatory fishes on juvenile river herring recruitment in an upstream impoundment. Master's Thesis, University of Maryland - Eastern Shore, Princess Anne, MD.

\section{SELECTED REPORTS:}

Atlantic States Marine Fisheries Commission, American Eel Stock Assessment Sub-Committee. 2012. American Eel stock assessment for peer review. Atlantic States Marine Fisheries Commission. 254 pages. 
U.S. Fish and Wildlife Service (S. Eyler). 2012. Silver Eel migrations at Conowingo Dam. Fall 2011 Study Results. U.S. Fish and Wildlife Service, Maryland Fishery Resources Office. 6 pages.

Welsh, S.A., D.R. Smith, S. Eyler, J.L. Zimmerman and M.T. Mandt. 2009. Migration of silver-phase and yellow-phase American Eel in relation to hydroelectric dams on the Shenandoah River. Phase IFinal Report. West Virginia University. 134pages.

Eyler, S., M. Mangold, and S. Minkkinen. 2009. Atlantic coast sturgeon tagging database. Summary Report. U.S. Fish and Wildlife Service, Maryland Fishery Resources Office, Annapolis, Maryland. 37 pages.

Eyler, S. 2007. Coast-wide horseshoe crab tagging program. Summary Report. U.S. Fish and Wildlife Service, Maryland Fishery Resources Office, Annapolis, Maryland. 43 pages.

Mangold, M.F., and S.M. Eyler. 2006 Chincoteague National Wildlife Refuge Fish Inventory Survey. Final Report. U.S. Fish and Wildlife Service, Maryland Fishery Resources Office, Annapolis, Maryland. 33 pages.

\section{SELECTED PRESENTATIONS:}

Eyler, S.M., S. Minkkinen, I. Park, and J. Devers. 2013. American Eel restoration to the Susquehanna River. Oral presentation to the Annual Meeting of the American Fisheries Society, Little Rock, AR.

Eyler, S., S. Welsh, D. Smith, and M. Mandt. 2011. Silver eel migration and mortality associated with five hydroelectric dams on the Shenandoah River. Poster Presentation for the Proceedings of a Workshop on American Eel Passage Technologies, Gloucester, MA.

Eyler, S., S. Welsh, D. Smith, and M. Mandt. 2010. Silver eel migration and mortality associated with five hydroelectric dams on the Shenandoah River. Oral presentation to the Annual Meeting of the American Fisheries Society, Pittsburg, PA.

Eyler, S.M., S.A. Welsh, D.R. Smith, M. Mandt. 2009. Silver eel migration and mortality associated with five hydroelectric dams on the Shenandoah River. Oral presentation to the Northeast Association of Fish and Wildlife Agencies Conference, Lancaster, PA.

Eyler, S.M., D. R. Smith, and M. J. Millard. 2007. Results and benefits of a coordinated Atlantic coast tagging program for horseshoe crabs. Poster presentation to the International Symposium on the Science and Conservation of Horseshoe Crabs, Oakdale, New York.

Eyler, S. M., L. E. Vogel, and F. J. Margraf. 2002. Effectiveness of a fish passage facility for anadromous river herring. Oral presentation to the 2002 Annual Conference of Southeastern Association of Fish and Wildlife Agencies, Baltimore, Maryland.

Eyler, S. M., and M. J. Millard. 2002. Tagging study to determine spawning frequency and beach fidelity of horseshoe crabs in Delaware Bay. Poster presentation to the American Fisheries Society $132^{\text {nd }}$ Annual Meeting, Baltimore, Maryland. Abstract 24194755-22. 
Eyler, S. M., M. F. Mangold, and J. E. Skjeveland. 2001. Reward program for sturgeon in the Maryland waters of the Chesapeake Bay. Poster presentation to the Northeast Association of Fish and Wildlife Agencies Conference, Saratoga Springs, New York.

AWARDS:

Best Paper Award in Transactions of the American Fisheries Society (2013)

Unsung Hero Award, U.S. Fish and Wildlife Service (2014)

MEMBERSHIPS AND PROFESSIONAL ASSOCIATIONS:

- American Fisheries Society - 1997 - present

○ Habitat Section Secretary/Treasurer - 2013 - present

COMMUNITY SERVICE:

- Treasurer - Parent/Teacher Organization, Fairview Elementary School, 2010-present

- Volunteer - Mont Alto Fire Department Events Complex, 2007 - present

- Instructor - Youth Day at Renfrew Institute for Cultural and Environmental Studies, 2012 present 